\title{
Mass spectrometry-based proteomics reveals the distinct nature of the skin proteomes of photoaged compared to intrinsically aged skin
}

DOI:

10.1111/ics. 12513

$10.1111 /$ ics. 12513

\section{Document Version}

Accepted author manuscript

Link to publication record in Manchester Research Explorer

Citation for published version (APA):

Newton, V. L., Riba-Garcia, I., Griffiths, C. E. M., Rawlings, A. V., Voegeli, R., Unwin, R. D., Sherratt, M. J., \& Watson, R. E. B. (2019). Mass spectrometry-based proteomics reveals the distinct nature of the skin proteomes of photoaged compared to intrinsically aged skin. International Journal of Cosmetic Science.

https://doi.org/10.1111/ics.12513, https://doi.org/10.1111/ics.12513

\section{Published in:}

International Journal of Cosmetic Science

\section{Citing this paper}

Please note that where the full-text provided on Manchester Research Explorer is the Author Accepted Manuscript or Proof version this may differ from the final Published version. If citing, it is advised that you check and use the publisher's definitive version.

\section{General rights}

Copyright and moral rights for the publications made accessible in the Research Explorer are retained by the authors and/or other copyright owners and it is a condition of accessing publications that users recognise and abide by the legal requirements associated with these rights.

\section{Takedown policy}

If you believe that this document breaches copyright please refer to the University of Manchester's Takedown Procedures [http://man.ac.uk/04Y6Bo] or contact uml.scholarlycommunications@manchester.ac.uk providing relevant details, so we can investigate your claim.

\section{OPEN ACCESS}




\section{Mass spectrometry-based proteomics reveals the distinct nature of the skin proteomes of photoaged compared to intrinsically aged skin}

Running Heading: Photoaged versus intrinsically aged skin proteomes

V.L Newton ${ }^{1,2}$, I Riba-Garcia ${ }^{3}$, C.E.M Griffiths ${ }^{1,2}$, A.V Rawlings ${ }^{4}$, R Voegeli ${ }^{5}$, R.D Unwin ${ }^{3}$, M.J Sherratt ${ }^{6 \$}$

\& R.E.B Watson ${ }^{1,2,5}$

${ }^{1}$ Centre for Dermatology Research, Division of Musculoskeletal \& Dermatological Sciences, School of Biological Sciences, Manchester Academic Health Science Centre, University of Manchester, and Salford Royal NHS Foundation Trust UK; ${ }^{2}$ NIHR Manchester Biomedical Research Centre, Central Manchester University Hospitals NHS Foundation Trust, Manchester Academic Health Science Centre, UK; ${ }^{3}$ Division of Cardiovascular Sciences, School of Medical Sciences, Faculty of Biology, Medicine and Health, University of Manchester, Manchester Academic Health Science Centre, Core Technology facility ( $3^{\text {rd }}$ Floor), 46 Grafton Street, Manchester, M13 9NT; ${ }^{4}$ AVR Consulting Ltd, Northwich, UK; ${ }^{5} D S M$ Nutritional Products Ltd, Kaiseraugst, Switzerland; ${ }^{6}$ Division of Cell Matrix Biology and Regenerative Medicine, School of Biological Sciences, Manchester Academic Health Science Centre, The University of Manchester, UK.

\$Joint senior authors.

victoria.newton@manchester.ac.uk; isabel_riba@hotmail.com; Christopher.Griffiths@manchester.ac.uk; tonyrawlings@avrconsultingltd.com; rainer.voegeli@dsm.com; r.unwin@manchester.ac.uk; michael.j.sherratt@manchester.ac.uk; rachel.watson@manchester.ac.uk.

Word Count: 5,513

Table count: 5

Figure count: 3

Corresponding author:

Dr Rachel Watson

Division of Musculoskeletal \& Dermatological Sciences The University of Manchester 2.001 Stopford Building Oxford Road Manchester M13 9PT

UK

Tel:

+44 1612755505

Fax: +441612755171

Email: rachel.watson@manchester.ac.uk

Conflicts of Interest Statement/Disclosures: DSM Nutritional Products Ltd have approved submission of the manuscript, but has exerted no editorial control of the content. MJS, RDU, IR-G and CEMC state no conflict of interest. VLN is funded by DSM Nutritional Products Ltd, RV is an employee of DSM Nutritional Products Ltd and AVR is consultant to DSM Nutritional Products Ltd. REBW is supported by a programme grant from Walgreens Boots Alliance (Nottingham, UK). 


\begin{abstract}
Objective

With increasing age skin is subject to alterations in its organisation, which impacts on its function as well as having clinical consequences. Proteomics is a useful tool for non-targeted, semi-quantitative simultaneous investigation of high numbers of proteins. In the current study we utilise proteomics to characterise and contrast age-associated differences in photoexposed and photoprotected skin, with a focus on the epidermis, dermal-epidermal junction and papillary dermis.
\end{abstract}

\title{
Methods
}

Skin biopsies from buttock (photoprotected) and forearm (photoexposed) of healthy volunteers (aged 18-30 or $\geq 65$ years) were transversely sectioned from the stratum corneum to a depth of 250 $\mu \mathrm{m}$. Following SDS-PAGE, each sample lane was segmented prior to analysis by liquid chromatography-mass spectrometry/mass spectrometry. Pathways analysis was carried out using Ingenuity IPA.

\section{Results}

Comparison of skin proteomes at buttock and forearm sites revealed differences in relative protein abundance. Ageing in skin on the photoexposed forearm resulted in $80 \%$ of the altered proteins being increased with age, in contrast to the photoprotected buttock where $74 \%$ of altered proteins with age were reduced. Functionally, age-altered proteins in the photoexposed forearm were associated with conferring structure, energy and metabolism. In the photoprotected buttock proteins associated with gene expression, free-radical scavenging, protein synthesis and protein degradation were most frequently altered.

\section{Conclusion}

This study highlights the necessity of not considering photoageing as an accelerated intrinsic ageing, but as a distinct physiological process.

\section{Key words:}

Genomics/Proteomics/Elisa/Cell culture; Skin physiology/structure; Skin ageing; Proteomics;

Epidermis; Dermis; Dermal-epidermal junction;

\section{Abbreviations:}

BU, buttock; DEJ, dermal-epidermal junction; ECM, extracellular matrix; FA, forearm; FDR, false discovery rate; GAPDH, glyceraldehyde-3-phosphate dehydrogenase; IQR, interquartile range; LC, liquid chromatography; MS, Mass spectrometry; OCTM, optimal cutting temperature media. 


\section{Introduction}

The skin changes with the passage of time, resulting from natural changes in the genome, gene expression and metabolism and is termed intrinsic ageing [1, 2]. However, the skin being of a large surface area and often exposed to the external environment means it is further influenced by factors such as weather, light and pollution [3-5]. It is these external factors exposed to throughout a lifetime, or a person's 'exposome', most particularly to sunlight, that contribute additional mechanisms to how the skin ages and is termed extrinsic ageing [6]. While the changes to the appearance of the skin as we age are often more subtle in those areas not frequently exposed, in those areas of skin which often are, most particularly in those who are paler, then skin can become wrinkled, course and mottled [7].

Much of the work carried out on how the skin changes with age has been focused on changes to the extracellular matrix (ECM) within the dermal compartment of the skin [8]. In the dermis ECM molecules are often very long lived and so accumulate damage over time, leading to differences in both their structural and mechanical properties. Other changes such as decreased collagen with respect to elastin, loss of small fibres of the elastin network close to the boarder with the dermis and changes to the glycosaminoglycan composition may also occur [8]. Less work has been carried out looking at the changes in the epidermis as we age, though it is known that epidermal thickness may reduce $[9,10]$, the rate of keratinocyte turnover slow [11] and that some keratinocytes may enter

senescence [12]. The dermal-epidermal junction (DEJ) between the epidermal and dermal compartments also undergoes alterations with age and while we know that it flattens, the reasons for this are still not fully understood [13].

Proteomics, using mass spectrometry (MS) to analyse peptide constituents in a sample allowing post-hoc identification of protein species [14], can be used as a non-targeted method to identify differences in relative abundance between samples. This has frequently been used successfully to identify novel biomarkers of disease $[15,16]$. Applying such a method to the skin, however, is not 
without its challenges, especially where the size of a skin sample through biopsy is limited and high concentrations of structural proteins in skin makes protein solubilisation and hence subsequent detection difficult. The high concentrations of ECM proteins present in the dermis and keratins in the epidermis can also mask changes in other less abundant proteins $[17,18]$.

Although proteomics on the skin has previously been carried out, to the best of our knowledge, ageing studies have thus far only evaluated whole biopsies taken from photoprotected areas. The aims of this study were therefore to use sectioning and SDS-PAGE separation prior to MS to improve skin protein solubilisation and detection. This strategy also allowed enrichment of samples for the epidermis, DEJ and papillary dermis and to reduce noise from proteins contained within the main volume of the dermis, including those from the vasculature. We then compared for the first time young and aged skin taken from a photoexposed site using non-targeted mass spectrometry. To be able to put into better context both the effect of sunlight on the skin as we age and proteomic differences due to anatomical site we also compared results to young and aged skin from a photoprotected skin site.

\section{Methods}

\section{Volunteers and biopsy removal}

Two panels of volunteers aged 18-30 years (mean: 24 years \pm 3 ) and 65 years or over (mean: 71 years \pm 4 ) were recruited into the study ( $n=6$ females per group; University of Manchester Research Ethics Committee ref 13268). All subjects gave written, informed consent and the study was carried out in accordance with the declaration of Helsinki guidelines (2013). Study subjects were Fitzpatrick skin phototype I-III [19]. An area of skin on the mid dorsal forearm (photoexposed) and an area of the photoprotected upper buttock/hip/lower back (photoprotected) were biopsied $(6 \mathrm{~mm})$ under local anaesthesia. Biopsies were rinsed in ice-cold phosphate buffered saline (PBS) twice, followed 
by ice-cold $0.25 \mathrm{M}$ sucrose to remove external blood before being bisected and snap-frozen in optimal cutting temperature medium (OCTM) using liquid nitrogen.

\section{Proteomics}

One half of the biopsy was orientated stratum corneum outermost in an OCTM block and as much excess OCTM surrounding the biopsy as possible removed. The first $5 \mu \mathrm{m}$ thick transverse/horizontal section of the skin was then collected from when the stratum corneum first became visible and collection continued to a depth of $250 \mu \mathrm{m}$. Sections were placed into $100 \mu \mathrm{L}$ of ice-cold lysis buffer (7 M urea, $2 \mathrm{M}$ thiourea, $30 \mathrm{mM}$ Tris- $\mathrm{HCl}$ to $\mathrm{pH}$ 8, followed by $50 \mathrm{mM} \mathrm{DTT}, 0.1 \%$ SDS), vortexed and frozen at $-80^{\circ} \mathrm{C}$ until required. In an attempt to minimise variation, only skin from female volunteers was used in the proteomics analyses.

Protein concentration was measured (FluoroProfile ${ }^{\circledR}$ Protein Quantification Kit; Sigma Aldrich; Gillingham, UK) and $30 \mu \mathrm{g}$ of each sample loaded onto an SDS-PAGE gel. Following separation gels were stained with Coomassie Blue to confirm equal loading and gel lines excised into 11 bands. Ingel digestion was then performed, beginning with three washes (200 mM ammonium bicarbonate, $40 \%(v / v)$ acetonitrile), until samples were translucent. Gel pieces were dried by incubation twice in $100 \%(\mathrm{v} / \mathrm{v})$ acetonitrile, then protein were reduced and alkylated by sequential incubation in $10 \mathrm{mM}$ dithiothreitol (20 mins), dehydration in 1 wash with acetonitrile, then incubation in $50 \mathrm{mM}$ iodoacetamide ( 30 mins). Gel pieces were then dried again by incubation in acetonitrile $(2 x)$ then rehydrated using $10-20 \mu \mathrm{L}$ of $20 \mathrm{ng} / \mu \mathrm{L}$ porcine sequencing grade modified trypsin (Promega: solution in $5 \%(\mathrm{v} / \mathrm{v})$ acetonitrile, $100 \mathrm{mM}$ ammonium bicarbonate. A further $50 \mu \mathrm{L}$ of $5 \%(\mathrm{v} / \mathrm{v})$ acetonitrile, $100 \mathrm{mM}$ ammonium bicarbonate was added and samples left to incubate overnight at $37^{\circ} \mathrm{C}$. Samples were then spun, the supernatant collected and $50 \mu \mathrm{L}$ of buffer ( $5 \%$ acetonitrile, 100 $\mathrm{mM}$ ammonium bicarbonate) added to each sample for 15 minutes to extract additional peptides. 
This was removed and pooled with the previous supernatant before drying using a SPEEDVAC. Samples were stored at $-80^{\circ} \mathrm{C}$ prior to reversed-phase liquid chromatography (LC)-MS/MS analysis.

For LC-MS/MS analysis, dried fractions were re-dissolved (20 $\mu \mathrm{L} ; 97 \% / 3 \%$ water/acetonitrile $v / v$, $0.1 \% \mathrm{v} / \mathrm{v}$ trifluoroacetic acid, $10 \mathrm{fmol}$ Glu-fibrinopeptide B, $10 \mathrm{fmol}$ Leu-enkephalin) and $3 \mu \mathrm{L}$ subjected to LC-MS analysis using a nanoACQUITY LC system (Waters, Elstree, UK) online to a QSTAR Elite mass spectrometer (AB Sciex, Framingham, USA). Briefly, injected samples were loaded onto a trapping column (Symmetry C18 100A, $5 \mu \mathrm{m}$; Waters) for 7.5 minutes using a flow rate of $15 \mu \mathrm{L} / \mathrm{min}$ $(98 \% / 2 \% \mathrm{v} / \mathrm{v}$ water/acetonitrile, $0.1 \%$ formic acid). The samples were resolved on an analytical column (NanoACQUITY UPLC ${ }^{\text {TM }}$ BEH $30 \mathrm{c} 18,75 \mu \mathrm{m} \times 250 \mathrm{~mm}, 1.7 \mu \mathrm{m}$; Waters, Elstree, UK) using the gradient shown in Table I at a flow rate of $300 \mathrm{~nL} / \mathrm{min}$. Columns were maintained at $40^{\circ} \mathrm{C}$.

The nanoACQUITY system was coupled to a $\mathrm{QSTAR}^{\circledR}$ Elite MS/MS System (AB Sciex) equipped with an electrospray ionisation (ESI) ion source. Ions were emitted from a Distal Coated Silica Tip Emitter needle $10 \pm 1 \mu \mathrm{m}$ (New Objective, Woburn, USA) and MS/MS collected using a standard IDA method where, following a 1 second MS scan, the four top precursor ions were selected and fragmented for 1 second each.

All MS/MS data files acquired from the same sample lane were processed together using ProteinPilot (AB Sciex) or Mascot DEAMON (Matrix Science Ltd, London, UK) and Scaffold 4 (Proteome Software, Portland, USA) to provide a single list of identifications from each sample.

\section{Data analysis}

Two data analysis workflows were used to identify differentially expressed proteins between groups.

ProteinPilot workflow: Raw data files were analysed using the Paragon algorithm within ProteinPilot 4.0 using default search settings against a Human-specific Uniprot database (Release April 2015, 
20,204 Entries), which was concatenated with a reversed-sequence decoy version of the same database to enable the false discovery rate (FDR) for identifications to be determined. To identify differentially expressed proteins, protein identification data from all of the samples was aligned using the Protein Alignment Template tool from AB Sciex. Proteins with Unused score $>2$ were included. To identify potentially differentially expressed proteins, the ' $N$ ', a value related to the relative abundance of each protein within each sample was calculated. Mean values were then calculated for each experimental group.

Mascot workflow: Data were also analysed using Mascot and the results processed using Scaffold 4.5.0 for identification of protein differences. Mascot searches were performed by combining data from all bands for a single sample into a single search using Mascot Daemon. Searches were carried out against a SwissProt 2015 Homo sapiens database using fragment tolerances of 0.8Da for precursor ions and 0.6 Da for product ions, with Met oxidation as a variable modification, carbamidomethylation (CAM) modified Cys as a fixed modification and using trypsin as the digesting enzyme with allowance for one missed cleavage. Resulting data files were imported into Scaffold software, where wide protein grouping with binary peptide protein weights was used. Peptide thresholds for positive protein identification were set to a minimum of $95 \%$, protein thresholds were set to $99 \%$ minimum and positive identification required at least 2 peptides per protein. FDR were set at $0.3 \%$ for peptides and at $0.4 \%$ for protein.

The list of proteins produced was manually reviewed in order to identify those that were missed by the software and to verify the results. Expression levels between samples were then compared in Scaffold by spectral counting, with an associated fold change and p-value calculated for each sample. The data were log transformed for graph plotting.

Pathways analysis was carried out using Ingenuity IPA software (Qiagen, Manchester, UK), where the entire user dataset was used as a background and differentially expressed proteins were defined as those with $0.7 \geq$ fold change $\geq 1.5$. 


\section{Results}

We first wanted to gain a sense of the influence of anatomical site on the skin proteome by comparing buttock and forearm skin. As buttock and forearm samples were not analysed on the MS on the same run, peptide numbers detected for each protein in buttock skin could not be directly compared with forearm. However, using ProteinPilot relative abundance could be compared, with the most abundant protein detected in an individual's sample designated 1 , the second most abundant 2 and so forth. A mean was then taken for each protein across the young individuals at each skin site. A highly abundant protein which was most different in relative abundance between the two sites was filaggrin, being relatively more abundant in the forearm (FA; the most abundantly detected) than the buttock (BU; the $8^{\text {th }}$ most abundantly detected; Fig $1 \mathrm{~A}(\mathrm{i})$ ). A number of other structural proteins that were relatively more abundant in the forearm compared with the buttock, included osteoglycine/mimecan ( $167^{\text {th }} \mathrm{FA}$ vs. $\left.355^{\text {th }} \mathrm{BU}\right)$, periplakin $\left(114^{\text {th }} \mathrm{FA}\right.$ vs. $\left.187^{\text {th }} \mathrm{BU}\right)$, a beta actin variant $\left(18^{\text {th }} \mathrm{FA}\right.$ vs. $\left.36^{\text {th }} \mathrm{BU}\right)$ and transgelin $\left(62^{\text {nd }} \mathrm{FA}\right.$ vs. $191^{\text {th }} \mathrm{BU}$; Fig 1 (i)). 14-3-3 sigma signalling molecule was also relatively more abundant in forearm than the buttock ( $39^{\text {th }} \mathrm{FA}$ vs. $52^{\text {nd }}$ $\mathrm{BU})$. Conversely, alpha-actinin $4\left(54^{\text {th }} \mathrm{FA}\right.$ vs. $\left.19^{\text {th }} \mathrm{BU}\right)$ and pyruvate kinase $\left(72^{\text {nd }} \mathrm{FA}\right.$ vs. $\left.36^{\text {th }} \mathrm{BU}\right)$, were relatively more abundant in the buttock skin than the forearm skin (See Supplementary Table I for full list).

Next we wanted to investigate the effect of ageing on the proteomes at each of the skin sites. Using Mascot and Scaffold software to analyse the data we detected a total of 377 proteins in samples taken from photoprotected buttock, the full list of which is in Supplementary Table II. Of these 377, 29 showed differential expression between young and aged skin $(p<0.05$ Table II). Those proteins more highly detected in aged buttock skin than young were structural (keratin $6 \mathrm{~A}$, fold change (FC) $648, p<0.01$ and filamin $\mathrm{A}, \mathrm{FC} 4, \mathrm{p}<0.05)$, along with two associated with clot formation; coagulation factor XIII (FC 6, p<0.01) and fibrinogen alpha chain (FC 3, p<0.05). Inositol monophosphase 2 
$(F C<0.001, p<0.05)$ and proteasome subunit alpha type-7-like protein $(F C<0.001, p<0.05)$ were the proteins most dramatically reduced in aged skin. Those proteins that changed were also organised by general function (as listed in UniProt), into stress response-, signalling-, energy and metabolism-, ubiquitin-proteasome-associated system-, immune-, protein synthesis-, structural-, transportation and/or metal-binding- and histone-related (Table 4).

In skin from photoexposed forearm, using Mascot and Scaffold, we detected more proteins than in the buttock (photoprotected) sample, 547 (see Supplementary Table III for full list). The 48 proteins where fold changes between young and aged skin had a p-value of 0.05 or less in photoexposed forearm are displayed in Table III. The most altered of these proteins being increased vitronectin with age (FC 1000, $p<0.001)$ and a reduction with age of leucyl-tRNA synthetase $(F C<0.001, p<0.05)$ and eukaryotic translation initiation factor 3 , subunit $B(F C<0.001, p<0.05)$. Those proteins that changed were also organised by general function (as listed in UniProt), with the largest groupings being those proteins associated with energy and metabolism, immune function, structure, and transportation/binding (Table IV).

The number of proteins that changed with age in the photoprotected buttock and photoexposed forearm were similar when considered as the percentage of detected proteins altered with age, $7 \%$ and $8 \%$ in buttock and forearm, respectively (where fold change was $\leq 0.7$ or $\geq 1.5$; Fig $2 \mathrm{~A}$ ). However, it was striking that not only were most altered proteins different at the two sites, but that in the buttock most altered proteins were reduced with age $(74 \%)$, whereas in the forearm most were increased with age (80\%). Only haemoglobin (alpha subunit), and coagulation factor XIII were altered with age at both sites with fold changes $\leq 0.7$ or $\geq 1.5$. Coagulation factor XIII (coag VIII) was increased with age in both the buttock (coag XIII FC 5.7, p<0.01) and forearm skin (coag XIII FC 2.7, 
$p<0.01)$, but haemoglobin alpha subunit was reduced with age in the buttock $(F C 0.4, p<0.05)$ and increased with age in the forearm (FC 14, p<0.05; Fig 2B).

To more systematically compare biological functions and molecular and cellular pathways altered as a result of each type of ageing, we carried out pathways analysis using Ingenuity IPA software on Mascot and Scaffold calculated results. In both buttock and forearm proteins changed with age were associated with cell death and survival. However, the actual proteins listed for each were not the same (except albumin) and as previously, while in buttock most of these proteins reduced with age, in forearm most increased. A number of proteins altered in forearm with age were associated with lipid metabolism, post-translational modification and hair and skin functioning. In buttock skin proteins with these function were either not altered or were not altered to the same degree by ageing. Instead, most proteins altered with ageing in the buttock were associated with gene expression, free-radical scavenging, protein synthesis and protein degradation, none of which were specified by IPA as changing with age in the forearm (Fig 3A, Table V).

\section{Discussion}

In this study we wanted to investigate photoageing using LC/MS/MS for the first time and to focus on protein changes in the epidermis, DEJ and the papillary dermis by enriching for this region prior to MS.

The horizontal sectioning of the skin biopsies to a depth of $250 \mu \mathrm{m}$ allowed collection of not only the epidermis, DEJ and upper dermis, but also aided in the solubilisation of proteins, as sections were only $5 \mu \mathrm{m}$ thick prior to lysis. Issues associated with the presence of OCTM in the samples were 
mitigated by the use of SDS-PAGE prior to MS. While probably not as sensitive as the use of stable isotope tagging (e.g. isobaric tags or dimethyl labelling, for example) for detection of differences in protein abundance between samples, the use of label-free proteomics for relative quantification is now common place [16]). Running proteins digested from each of the gel fragments separately allowed for detection of a greater number of proteins. This is because if each of our samples had been loaded onto the MS without gel separation first and using a single injection, keratins and other more common proteins would have swamped the MS signal. Despite our technique enriching the epidermis and upper dermis in our sample preparation and separating the samples using gels, we did not detect some low abundance proteins, including those contained within the DEJ such as nidogen and laminin 5/332. However, this was also the case in a study where laser capture was employed to specifically extract the DEJ [20], highlighting the difficultly in detecting proteins from a region only approximately $150 \mathrm{~nm}$ in thickness [21]. Despite this, the number of proteins detected overall using Mascot and Scaffold in this study was broadly comparable to previous studies that used whole biopsies and that would have had more tissue available for analysis [22, 23]. Proteomics studies on the skin are therefore still far short of the 825 epidermal, 1636 dermal and epidermal, 95 dermal and $32 \mathrm{DEJ} /$ basement membrane proteins now known, as reported by a systematic review on proteins present in the skin [24].

\section{Protein abundance in photoexposed forearm skin compared with photoprotected buttock skin}

Comparison of the relative abundance of proteins in the forearm skin with the buttock skin in young individuals revealed differences and highlights that the skin proteome varies between anatomical site, even before exposome differences have had time to cause further impact. Many of the differences associated with anatomical site included proteins with a structural- and/or matrixrelated role. This was true of filaggrin, which was the most relatively abundant protein in the forearm, but only the eighth most relatively abundant protein in the buttock. Also, 
mimecan/osteoglycine, periplakin, a beta actin variant and transgelin were all more relatively abundant in young forearm compared with the buttock. Both filaggrin and periplakin are vital for cornification and barrier function and in a study in which skin keratinocytes were exposed to cigarette smoke condensate, both periplakin and filaggrin were up-regulated [25]. Filaggrin is also enriched in the stratum corneum on the cheek compared to a post-auricular site where skin is protected from sunlight [26]. It is possible that differences between forearm and buttock skin were due to external factors, even in young skin, though these differences may have been a consequence of a thicker stratum corneum, which has been observed on the dorsal forearm compared with the buttock [27]. The higher relative levels of a beta actin variant and of transgelin, important in actin dynamics, suggests that the actin cytoskeleton may be different in forearm skin compared with buttock skin. So, too does the finding of alpha-catenins being more relatively abundant in buttock than sun-exposed dorsal forearm skin. These proteins are actin filament-associated proteins and important in maintaining cellular adhesion via $\beta$-catenin and E-cadherin through the actin network [28]. A reduction of alpha-catenin 1 is associated with an increase in NF-KB activation and hyperproliferation [29], again suggesting differences in the actin network and differences in the number and properties of adherence junctions in buttock skin compared with forearm skin. The small leucine-rich proteoglycan mimecan/osteoglycine is thought to control collagen fibre development, with increased fibre thickness observed in mutant mice [30]. In human abdominal skin collagen fibres are thicker in aged skin [31], though whether there are differences in fibre thicknesses in the forearm compared with the buttock is not, to the best of our knowledge, known. It is known however that transcription of mimecan is induced in response to UV [32], so it is possible that even short term-exposure to UV might result in more of this protein and so account for the relatively higher amount in forearm skin than buttock. Non-structural proteins less relatively abundant in forearm compared with buttock included pyruvate kinase and ubiquitin carboxyl terminal hydrolase 5. Pyruvate kinase expression has been linked with controlling the rate of nucleotide synthesis by virtue of nucleotide synthesis being critical for cell proliferation [33]. It is 
possible that rates of cell proliferation in forearm skin and buttock skin may differ and be linked with levels of pyruvate kinase. Carboxyl terminal hydrolase 5 is a protease that hydrolyses a peptide bond at the C-terminal glycine of ubiquitin [34]. Reductions in this protein in vitro reduce the degradation of ubiqutinated p53 and so result in higher levels of activated p53 [35]. Therefore this may be a mechanism by which the presence of activated p53 is increased and so accelerate cellular apoptosis and/or senescence in forearm skin [36]. As a result, given that the ideal of a longitudinal study is not practical in most instances, ageing studies must bear in mind the additional variation induced by variation in anatomical site in addition to changes caused by a person's exposome, such as the variation already shown in fibroblast gene expression of cells located at different anatomical sites $[37,38]$.

\section{Protein abundance in young \& aged photoexposed forearm skin}

Comparison of proteins in young and aged skin in the photoexposed forearm showed that while there were reductions of a trifunctional mitochondrial enzyme, a t-RNA synthetase and a translation initiation factor, most proteins increased in detection with age. The increased levels of vitronectin and, in particular, elastin in the photoexposed forearm have been known for many years [39]. Elastin is deposited as a disorganised amorphous mass [solar elastosis] and ECM proteins such as vitronectin and clusterin bind the edges of these dermal elastic fibres [40]. Indeed, clusterin glycoprotein may be produced in response to stress and is found closely associated with elastin in solar elastosis, thought to be as an attempt to reduce elastin aggregation [41]. Agreement of our proteomic results with previous studies therefore help in validating the findings of this study. Transthyretin and amyloid $\mathrm{P}$ are also associated with matrix deposition/amyloidosis, with transthyretin a transporter protein of thyroxine and retinol. Abnormal deposition of this protein is known to occur in some elderly individuals, especially in cardiac tissue [42]. It is also found associated with peripheral nerves and amyloid $\mathrm{P}$ in cases of familial amyloidotic polyneuropathy 
[43], though the increased levels detected with age in the forearm in our experiment may be the result of increased serum levels rather than increased deposition in the skin. Another structureassociated protein higher in aged skin in our study was spectrin. Spectrin helps maintain the stability, shape and structure of the cell contributing to cell adhesion, spreading and the cell cycle. Spectrin can be degraded by the calcium-dependent protease calpain and the activity of this protease is increased in fibroblasts from aged donors than young [44]. It is therefore possible that more of this protein was detected with age as the skin attempts to compensate for the increased cleavage of this protein. However, it may also be that the cleaved spectrin products were more readily detectable by our methodology than the full length protein. With such clear evidence of elastosis in our aged forearm skin samples we expected that we might find evidence of loss of DEJassociated proteins as has previously be found in photoaged skin [13]. As previously discussed, we did not detect a number of DEJ-associated proteins due to their scarcity, but we did detect collagen VII and alpha- 6 and beta- 4 integrins. These were not significantly reduced with age in our data set as might be expected. Our skin samples therefore may have exhibited histology such as that surrounding some wrinkles, where ECM deposition is significant, but the DEJ appears relatively normal [45]. Deposition of ECM and other associated proteins was therefore the major driver of the proteomic differences observed in photoageing in this study.

\section{Protein abundance in young \& aged photoprotected buttock skin}

By comparison ageing changes in photoprotected buttock were very different, where although there was a structural protein, Keratin $6 \mathrm{~A}$, top of the list as increased with age, most of the other changes were reductions in the amount of proteins detected with age. Keratin 6A mRNA expression has been shown to be increased with age in sun protected human skin $[46,47]$, though we did not find a concurrent increase in its binding partner keratin 16 with age. Filamin $A$ is an actin binding protein and is known to be important in the pericellular organisation of collagen [48] and providing tension 
to the ECM [49]. Alterations in this protein with age in the skin have not to our knowledge been reported previously, though it is known that mutations in filamin A can lead to cutaneous alterations including fibromas and pigmentary changes [50]. Filamin $A$ is also known to influence TGF- $\beta$ signalling through modulation of RhoA and SMAD trafficking, but also influence the negative regulation of both ERK1/2 and MMP signalling via a RAS-GRF1 $[51,52]$. Therefore, it is possible that the increase in filamin A with age could be a reflection of changes in ECM dynamics in response to increased levels of MMP 9 with age or an attempt to increase SMAD2/TGF- $\beta$ signalling in the aged skin. Among the most reduced proteins with age in the buttock were phosphoglycerate mutase 1, proteasome alpha subunits and inositol monophosphatase 2. A recent transcriptome study found inositol monophosphatase 2 to be higher in aged skin [53], however in this study we found the opposite to be true at the protein level. It is possible that the increase in the transcription of this enzyme is in response to lower cellular levels of the protein, if with age the rate of turnover increases or rate of translation reduces. It does however suggest that changes to inositol phosphate metabolism are important as we age and may be linked to keratinocyte differentiation and proliferation, as well as their regulation [54]. Protein degradation is affected by ageing [55] and so it is unsurprising that we found proteins associated with the proteasome pathway to be altered with age. This has been shown to manifest as a reduction in proteasome subunit expression [56] and indeed we observed a reduction in both proteasome subunit alpha type 1 and type-7-like protein. Phosphoglycerate mutase catalyses the interconversion of 3-phosphoglycerate and 2phosphoglycerate in glycolysis, two steps after GAPDH [57] and so suggests more anaerobic metabolism in the young buttock skin. That being said, the balance of glycolytic enzymes is complex, not all have an effect on the rate of glycolysis and not only the presence or absence of a protein needs to be considered, but its activation and inhibition. Temporal factors are also important, as responses may be dependent on what the cell has previously been exposed to in its environment [58]. In embryonic mouse fibroblasts phosphoglycerate mutase upregulation increases the rate of glycolysis and protects against oxidative stress, its depletion induces cellular senescence and, in 
contradiction to the anaerobic theory of ageing, in mouse fibroblasts at least, oxidative stress will lead to an inhibition of glycolysis [58]. Reduced levels of phosphoglycerate mutase in aged buttock skin may therefore be a hallmark of cellular senescence in the intrinsically aged skin.

\section{Functionality groupings of those proteins changed with age and sun-exposure}

Division of changed proteins with age into functions revealed that proteins associated with structure, energy and metabolism; more specifically, hair and skin functioning, lipid metabolism and post-translational modification were predominant or unique to the forearm site. Hair and skinspecific processes being pulled out by IPA as changing with photoageing was due to the predominance of de-novo synthesis of many structural proteins associated with amyloid-type deposition as discussed above. However, it must also be remembered that structural proteins newly synthesised or fragmented as a result of photoexposure do not possess the same physical properties as ECM in its usual architecture [59]. For example, this material may be more soluble and so could be present in higher concentrations in samples prepared for MS. Indeed, this is perhaps the reason for the detection of more collagen in the aged forearm skin in our study, as although in photoexposed sites overall collagen levels may reduce, fibers are fragmented, thickened, and more soluble [60]. It may also be why more proteins overall were detected in the forearm compared with the buttock despite the same mass of protein being loaded for each. More proteins were also detected in a proteomics study using tape strips taken from the photoexposed cheek [ 436 protein detected] compared with a photoprotected post-auricular site (253 proteins detected) [26], perhaps suggesting that exposure to sunlight either expands the number of proteins present within the skin or changes the properties of those proteins present allowing them to be more readily detected by MS. 
Those proteins identified as being associated with lipid metabolism in photoaged skin in this study including apolipoprotein $A$ and clusterin are known to be increased in plasma with age $[61,62]$ and so their increased presence may less be indicative of changes in lipid metabolism and more point to their detection in any residual blood in the tissue samples and/or increased vessel leakage in aged skin [63]. Many of these proteins are also common to the process of ECM deposition as previously discussed and so their increased presence be linked to the elastosis process rather than changes in lipid metabolism.

Proteins associated with post-translational modification are becoming of more interest as their link with diseases associated with ageing are studied. Protein phosphorylation, acetylation, methylation, and ubiquitination may not just be markers of ageing and ageing-related diseases, but may also be implicated in disease causation [64], though the proteins identified by IPA analysis in our analysis linked to post-translational modification were limited.

In common with photoaged skin, cell death and survival, cellular assembly and organisation, cellular movement and cell-cell signalling were processes in which proteins were altered with intrinsic ageing. However, contrary to photoaged skin, protein function types additionally altered were associated with gene expression, free-radical scavenging, protein synthesis and protein degradation. The proteins involved in protein synthesis, eukaryotic initiation factor 4A, eukaryotic translation initiation factor 3, subunit B, 40S ribosomal protein S3, elongation factor 1-gamma and leucyl-tRNA synthetase, all tended towards a loss with age and it is known from a number of studies that general protein synthesis rates decline with age [65]. Protein synthesis requires a high rate of energy usage and maintaining low levels of protein synthesis helps to aid in longevity. However, protein synthesis is essential to replace damaged proteins [65]. In photoprotected skin this reduction in protein synthesis may be more acceptable due to lower levels of accumulative damage as a result of protection from light and other environmental factors. By contrast, in photoexposed sites, skin is 
regularly challenged by external factors causing damage to proteins and so protein synthesis may need to be maintained at a higher rate in order to replace these damaged proteins. Within the group of free-radical scavenging proteins reduced with age, DJ-1, to the best of our knowledge has not before been associated with skin ageing. Reduced levels of DJ-1 have previously been reported with age in the thymus [66], though DJ-1 is best known for its association with Parkinson's disease, as mutations in this protein can lead to early onset [67]. DJ-1 is also important in response to UV and this has been shown in vitro in both a human corneal endothelial cell line [68] and also a HaCaT keratinocyte cell line [69]. More recently an increase in DJ-1 expression in vivo in the stratum corneum has been shown to result from UVB irradiation [70]. Also, higher levels of DJ-1 protein have been measured in the stratum corneum of photoexposed cheek compared with the photoprotected post auricular site [26]. Other anti-oxidant/cell repair proteins found reduced with age in the photoprotected buttock were peroxiredoxin-1, RAC 1 and heat shock protein beta-1, all of which have been shown to be reduced as a result of ageing and/or linked to UV exposure previously [7173]. Ageing in photoprotected skin therefore tends towards reduced proliferation, reduced protein synthesis and a reduction in capacity to react to cellular stress, fitting with the ageing theory in that accumulation of oxidatively damaged proteins in ageing cells results in the loss of function of gene products critical for maintaining genome integrity [74].

\section{Conclusion}

In this study we have shown that there are proteome differences in skin at different anatomical sites, even prior to the added complexity of ageing. We have identified filamin A and DJ-1 as potential markers of skin ageing, though the number of volunteers in this study was small and both would need to be confirmed by alternative experimental means. We have found that ageing induces changes in the proteome in the photoexposed forearm and that these predominate in the direction of protein induction, in stark contrast to the photoprotected buttock, where loss of protein 
abundance predominates. It is possible that this may be linked to methylation, as hypermethylation has been measured in intristically aged skin, and hypomethylation in extrinstically aged [75]. This coupled with the differences in the functions of the proteins changing with age at the two sites highlights the distinct nature of photoageing compared with ageing at a photoprotected site, even taking into account the differences that already exist as a result of anatomical location. Therefore, this study highlights the necessity of considering photoageing not as an accelerated intrinsic ageing, but as a distinct physiological process.

\section{References}

1. Brink TC, Demetrius L, Lehrach $\mathrm{H}$, Adjaye J. Age-related transcriptional changes in gene expression in different organs of mice support the metabolic stability theory of aging. Biogerontology. 2009;10(5):549-64.

2. Farage MA, Miller KW, Elsner P, Maibach HI. Intrinsic and extrinsic factors in skin ageing: a review. Int J Cosmet Sci. 2008;30(2):87-95.

3. Loffler $\mathrm{H}$, Happle R. Influence of climatic conditions on the irritant patch test with sodium lauryl sulphate. Acta Dermato-Venereologica. 2003;83(5):338-41.

4. Tsoureli-Nikita E, Watson REB, Griffiths CEM. Photoageing: the darker side of the sun. Photochem Photobiol Sci. 2006;5(2):160-4.

5. Mancebo SE, Wang SQ. Recognizing the impact of ambient air pollution on skin health. J Eur Acad Dermatol Venereol. 2015;29(12):2326-32.

6. Krutmann J, Bouloc A, Sore G, Bernard BA, Passeron T. The skin aging exposome. J Dermatol Sci. 2017;85(3):152-61.

7. Watson R, Griffiths C. Pathogenic aspects of cutaneous photoaging. J Cosmet Dermatol. 2005;4(4):230-6.

8. Naylor EC, Watson REB, Sherratt MJ. Molecular aspects of skin ageing. Maturitas. 2011;69(3):249-56.

9. Lavker RM. Structural alterations in exposed and unexposed aged skin. J Investig Dermatol. 1979;73(1):59-66.

10. Giangreco A, Goldie SJ, Failla V, Saintigny G, Watt FM. Human Skin Aging Is Associated with Reduced Expression of the Stem Cell Markers [beta]1 Integrin and MCSP. J Invest Dermatol. 2009;130(2):604-8.

11. Grove GL, Kligman AM. Age-associated changes in human epidermal-cell renewal. J Gerontol. 1983;38(2):137-42.

12. Dimri GP, Lee XH, Basile G, Acosta M, Scott C, Roskelley C, et al. A biomarker that identifies senescent human-cells in culture and in ageing skin in-vivo. Proc Natl Acad Sci U $S$ A. 1995;92(20):9363-7. 
13. Amano S. Possible Involvement of Basement Membrane Damage in Skin Photoaging. J Investig Dermatol Symp Proc. 2009;14(1):2-7.

14. Lombard-Banek C, Portero EP, Onjiko RM, Nemes P. New-generation mass spectrometry expands the toolbox of cell and developmental biology. genesis. 2017;55(1-2):e23012.

15. Fujii K, Nakamura H, Nishimura T. Recent mass spectrometry-based proteomics for biomarker discovery in lung cancer, COPD, and asthma. Expert Rev Proteomics. 2017;14(4):373-86.

16. Lindemann C, Thomanek N, Hundt F, Lerari T, Meyer Helmut E, Wolters D, et al. Strategies in relative and absolute quantitative mass spectrometry based proteomics. bchm. 2017;398(5-6):687.

17. Naba A, Clauser KR, Ding H, Whittaker CA, Carr SA, Hynes RO. The extracellular matrix: Tools and insights for the "omics" era. Matrix Biol. 2016;49:10-24.

18. Angel TE, Aryal UK, Hengel SM, Baker ES, Kelly RT, Robinson EW, et al. Mass spectrometry based proteomics: existing capabilities and future directions. Chem Soc Rev. 2012;41(10):3912-28.

19. Fitzpatrick TB. The validity and practicality of sun-reactive skin types $i$ through vi. Arch Dermatol. 1988;124(6):869-71.

20. Mikesh LM, Aramadhaka LR, Moskaluk C, Zigrino P, Mauch C, Fox JW. Proteomic anatomy of human skin. J Proteomics. 2013;84:190-200.

21. McMillan JR, Akiyama M, Shimizu H. Epidermal basement membrane zone components: ultrastructural distribution and molecular interactions. J Dermatol Sci. 2003;31(3):169-77.

22. Moon E, Park HM, Lee CH, Do S-G, Park J-M, Han N-Y, et al. Dihydrolipoyl dehydrogenase as a potential UVB target in skin epidermis; using an integrated approach of label-free quantitative proteomics and targeted metabolite analysis. J Proteomics 2015;117:70-85.

23. Parkinson E, Skipp P, Aleksic M, Garrow A, Dadd T, Hughes M, et al. Proteomic Analysis of the Human Skin Proteome after In Vivo Treatment with Sodium Dodecyl Sulphate. PLoS ONE. 2014;9(5):e97772.

24. Hibbert SA, Ozols M, Griffiths CEM, Watson REB, Bell M, Sherratt MJ. Defining tissue proteomes by systematic literature review. Sci Rep 2018;8(1):546.

25. Rajagopalan P, Nanjappa V, Raja R, Jain AP, Mangalaparthi KK, Sathe GJ, et al. How Does Chronic Cigarette Smoke Exposure Affect Human Skin? A Global Proteomics Study in Primary Human Keratinocytes. OMICS. 2016;20(11):615-26.

26. Voegeli R, Monneuse JM, Schoop R, Summers B, Rawlings AV. The effect of photodamage on the female Caucasian facial stratum corneum corneome using mass spectrometry-based proteomics. Int J Cosmet Sci. 2017;39 (6):637-52.

27. Sandby-Møller J, Poulsen T, Wulf HC. Epidermal thickness at different body sites: relationship to age, gender, pigmentation, blood content, skin type and smoking habits. Acta Derm Venereol 2003;83(6):410-3.

28. Gul IS, Hulpiau P, Saeys Y, van Roy F. Evolution and diversity of cadherins and catenins. Exp Cell Res. 2017;358(1):3-9.

29. Kobielak A, Fuchs E. Links between $\alpha$-catenin, NF-KB, and squamous cell carcinoma in skin. Proc Natl Acad Sci U S A. 2006;103(7):2322-7.

30. Tasheva ES, Koester A, Paulsen AQ, Garrett AS, Boyle DL, Davidson HJ, et al. Mimecan/osteoglycin-deficient mice have collagen fibril abnormalities. Mol Vis. 2002;8(42):407-15.

31. Lovell CR, Smolenski KA, Duance VC, Light ND, Young S, Dyson M. Type I and III collagen content and fibre distribution in normal human skin during ageing. $\mathrm{Br} J$ Dermatol 1987;117(4):41928.

32. Tasheva E, Conrad G. The UV responsive elements in the human mimecan promoter: A functional characterization. Mol Vis. 2003;9(1):1-9.

33. Lunt SY, Muralidhar V, Hosios AM, Israelsen WJ, Gui DY, Newhouse L, et al. Pyruvate kinase isoform expression alters nucleotide synthesis to impact cell proliferation. Mol Cell 2015;57(1):95107.

34. Pickart CM, Rose IA. Ubiquitin carboxyl-terminal hydrolase acts on ubiquitin carboxylterminal amides. J Biol Chem. 1985;260(13):7903-10. 
35. Dayal S, Sparks A, Jacob J, Allende-Vega N, Lane DP, Saville MK. Suppression of the Deubiquitinating Enzyme USP5 Causes the Accumulation of Unanchored Polyubiquitin and the Activation of p53. J Biol Chem. 2009;284(8):5030-41.

36. Rodier F, Campisi J, Bhaumik D. Two faces of p53: aging and tumor suppression. Nucleic Acids Res. 2007;35(22):7475-84.

37. Rinn JL, Bondre C, Gladstone HB, Brown PO, Chang HY. Anatomic Demarcation by Positional Variation in Fibroblast Gene Expression Programs. PLoS Genet. 2006;2(7):e119.

38. Chang HY, Chi J-T, Dudoit S, Bondre C, van de Rijn M, Botstein D, et al. Diversity, topographic differentiation, and positional memory in human fibroblasts. Proc Natl Acad Sci U S A. 2002;99(20):12877-82.

39. Lavker RM, Zheng PS, Dong G. Aged skin: a study by light, transmission electron, and scanning electron microscopy. J Invest Dermatol 1987;88(3 Suppl):44s-51s.

40. Dahlback K, Ljungquist A, Lofberg H, Dahlback B, Engvall E, Sakai LY. Fibrillin immunoreactive fibers constitute a unique network in the human dermis: Immunohistochemical comparison of the distributions of fibrillin, vitronectin, amyloid $\mathrm{P}$ component, and orcein stainable structures in normal skin and elastosis. J Invest Dermatol. 1990;94(3):284 - 91.

41. Janig E, Haslbeck $M$, Aigelsreiter $A$, Braun N, Unterthor D, Wolf $P$, et al. Clusterin Associates with Altered Elastic Fibers in Human Photoaged Skin and Prevents Elastin from Ultraviolet-Induced Aggregation in Vitro. Am J Pathol. 2007;171(5):1474-82.

42. Dharmarajan K, Maurer MS. Transthyretin Cardiac Amyloidoses in Older North Americans. J Am Geriatr Soc. 2012;60(4):765-74.

43. Ueno S, Fujimura H, Yorifuji S, Nakamura Y, Takahashi M, Tarui S, et al. Familial amyloid polyneuropathy associated with the transthyretin cys114 gene in a Japanese kindred. Brain. 1992;115(5):1275-89.

44. Peterson C, Vanderklish P, Seubert P, Cotman C, Lynch G. Increased spectrin proteolysis in fibroblasts from aged and Alzheimer donors. Neurosci Lett. 1991;121(1-2):239-43.

45. Scott I, Green MR. The human periorbital wrinkle. In: Baran R, Maibach HI, editors. Textbook of Cosmetic Dermatology: CRC Press Book; 2005. p. 277-82.

46. Oender $K$, Trost A, Lanschuetzer $C$, Laimer $M$, Emberger $M$, Breitenbach $M$, et al. Cytokeratin-related loss of cellular integrity is not a major driving force of human intrinsic skin aging. Mech Ageing Dev. 2008;129(10):563-71.

47. Lener T, Moll PR, Rinnerthaler M, Bauer JW, Aberger F, Richter K. Expression profiling of aging in the human skin. Exp Gerontol. 2006;41(4):387-97.

48. Mezawa M, Pinto VI, Kazembe MP, Lee WS, McCulloch CA. Filamin A regulates the organization and remodeling of the pericellular collagen matrix. Faseb J. 2016;30(10):3613-27.

49. Mohammadi H, Pinto VI, Wang Y, Hinz B, Janmey PA, McCulloch CA. Filamin A Mediates Wound Closure by Promoting Elastic Deformation and Maintenance of Tension in the Collagen Matrix. J Invest Dermatol. 2015;135(11):2852-61.

50. Bhabha FK, Walsh M, Orchard D, Savarirayan R. Terminal osseous dysplasia with pigmentary defects; Case and brief review of filamin A-related disorders. Australas J Dermatol. 2015;57:312-5.

51. Sasaki A, Masuda Y, Ohta Y, Ikeda K, Watanabe K. Filamin Associates with Smads and Regulates Transforming Growth Factor- $\beta$ Signaling. J Biol Chem 2001;276(21):17871-7.

52. Zhu T-N, He H-J, Kole S, D'Souza T, Agarwal R, Morin PJ, et al. Filamin A-mediated Downregulation of the Exchange Factor Ras-GRF1 Correlates with Decreased Matrix Metalloproteinase-9 Expression in Human Melanoma Cells. J Biol Chem. 2007;282(20):14816-26.

53. Kuehne A, Hildebrand J, Soehle J, Wenck H, Terstegen L, Gallinat S, et al. An integrative metabolomics and transcriptomics study to identify metabolic alterations in aged skin of humans in vivo. BMC Genomics. 2017;18(1):169.

54. Jaken S, Yuspa SH. Early signals for keratinocyte differentiation: role of $\mathrm{Ca} 2+$-mediated inositol lipid metabolism in normal and neoplastic epidermal cells. Carcinogenesis. 1988;9. 
55. Grune T, Shringarpure R, Sitte N, Davies K. Age-related changes in protein oxidation and proteolysis in mammalian cells. J Gerontol A Biol Sci Med Sci. 2001;56(11):B459-B67.

56. Vernace VA, Schmidt-Glenewinkel T, Figueiredo-Pereira ME. Aging and regulated protein degradation: who has the UPPer hand? Aging Cell. 2007;6(5):599-606.

57. Adachi K, Yamasawa S. Quantitative Histochemistry of the Primate Skin. J Invest Dermatol. 1967;49(1):22-30.

58. Kondoh H, Lleonart ME, Gil J, Wang J, Degan P, Peters G, et al. Glycolytic Enzymes Can Modulate Cellular Life Span. Cancer Res. 2005;65(1):177-85.

59. Sherratt M. Tissue elasticity and the ageing elastic fibre. Age. 2009;31:305 - 25.

60. Waller J, Maibach $\mathrm{H}$. Age and skin structure and function, a quantitative approach (II): protein, glycosaminoglycan, water, and lipid content and structure. Skin Res Technol. 2006;12:145 54.

61. Harukuni A, Miyao M, Hitoshi S, Hirotoshi F, Hitoshi C. Effect of ageing on plasma lipoprotein(a) levels. Ann Clin Biochem 2002;39(3):237-40.

62. Baralla A, Sotgiu E, Deiana M, Pasella S, Pinna S, Mannu A, et al. Plasma Clusterin and Lipid Profile: A Link with Aging and Cardiovascular Diseases in a Population with a Consistent Number of Centenarians. PLoS One. 2015;10(6):e0128029.

63. Oakley R, Tharakan B. Vascular Hyperpermeability and Aging. Aging Dis. 2014;5(2):114-25.

64. Santos AL, Lindner AB. Protein Posttranslational Modifications: Roles in Aging and AgeRelated Disease. Oxid Med Cell Longev. 2017;2017:5716409.

65. Tavernarakis N. Ageing and the regulation of protein synthesis: a balancing act? Trends Cell Biol. 2008;18(5):228-35.

66. Ismail IA, El-Bakry HA, Soliman SS. Melatonin and tumeric ameliorate aging-induced changes: implication of immunoglobulins, cytokines, DJ-1/NRF2 and apoptosis regulation. Int J Physiol Pathophysiol Pharmacol. 2018;10(2):70-82.

67. Bonifati V, Rizzu P, van Baren MJ, Schaap O, Breedveld GJ, Krieger E, et al. Mutations in the DJ-1 gene associated with autosomal recessive early-onset parkinsonism. Science. 2003;299.

68. Liu C, Chen Y, Kochevar IE, Jurkunas UV. Decreased DJ-1 Leads to Impaired Nrf2-Regulated Antioxidant Defense and Increased UV-A-Induced Apoptosis in Corneal Endothelial CellsDJ-1 Deficiency Increases Oxidative Damage in CECs. Invest Ophthalmol Vis Sci. 2014;55(9):5551-60.

69. Advedissian T, Deshayes F, Poirier F, Viguier M, Richarme G. The Parkinsonism-Associated Protein DJ-1/Park7 Prevents Glycation Damage In Human Keratinocyte. Biochem Biophys Res Commun. 2016;473(1):87-91.

70. Ishiwatari S, Takahashi M, Yasuda C, Nakagawa M, Saito Y, Noguchi N, et al. The protective role of DJ-1 in ultraviolet-induced damage of human skin: DJ-1 levels in the stratum corneum as an indicator of antioxidative defense. Arch Dermatol Res. 2015;307(10):925-35.

71. Nyström T, Yang J, Molin M. Peroxiredoxins, gerontogenes linking aging to genome instability and cancer. Genes Dev. 2012;26(18):2001-8.

72. Deshmukh J, Pofahl R, Haase I. Epidermal Rac1 regulates the DNA damage response and protects from UV-light-induced keratinocyte apoptosis and skin carcinogenesis. Cell Death Dis. 2017;8(3):e2664.

73. Calderwood SK, Murshid A, Prince T. The Shock of Aging: Molecular Chaperones and the Heat Shock Response in Longevity and Aging - A Mini-Review. Gerontology. 2009;55(5):550-8.

74. McMurray MA, Gottschling DE. Genetic Instability in Aging Yeast: A Metastable Hyperrecombinational State. Cold Spring Harb Symp Quant Biol. 2004;69:339-48.

75. Grönniger E, Weber B, Heil O, Peters N, Stäb F, Wenck H, et al. Aging and Chronic Sun Exposure Cause Distinct Epigenetic Changes in Human Skin. PLoS Genet. 2010;6(5):e1000971. 


\section{Tables Legends}

Table I: Solvent gradients applied to the NanoACQUITY UPLC ${ }^{\mathrm{TM}}$ BEH 30 c18 column prior to loading onto the MS.

Table II: List of proteins and their accession numbers that showed a significant change in aged photoprotected buttock skin compared with young. Green shading represents where there is more of a protein in aged skin than young by a factor of 1.5 or more and blue shading represents where there is less of a protein in aged skin compared with young by a factor of 0.7 or less. All protein fold changes exhibited possess $p$ values of 0.05 or less.

Table III: List of proteins and their accession numbers that showed a significant change in aged forearm skin compared with young. Green shading represents where there is more of a protein in aged skin than young by a factor of 1.5 or more and blue shading represents where there is less of a protein in aged skin compared with young by a factor of 0.7 or less. All protein fold changes exhibited possess $p$ values of 0.05 or less.

Table IV: General functional groupings of changed proteins with age in the buttock and forearm skin. Proteins where a difference with age was detected grouped into general functions as listed in UniProt. All proteins displayed exhibit $p$ values of 0.05 or less. Green represents an increase in aged skin and blue a reduction.

Table V: IPA grouping of changed proteins by their molecular and cellular functions. Proteins where a difference with age was detected grouped into molecular and cellular functions by IPA Ingenuity. All proteins displayed exhibit $p$ values of 0.05 or less. Green represents an increase in aged skin and blue a reduction. Fold changes of $0.7 \leq \& \geq 1.5$ were considered in the IPA analysis.

\section{Figure Legends}

Figure 1: Differences in relative protein abundance between young buttock and forearm skin sites. Comparison between data sets where each protein is ranked by its abundance relative to the other proteins present in the same sample. For example, the most abundant protein in the sample is designated 1 , the second most abundant 2 and so forth. Abundance values were averaged across young samples for each skin site. [i] Relative protein abundance between young buttock and young forearm up to the $400^{\text {th }}$ most relatively abundant protein. [ii] Relative protein abundance between young buttock and forearm up to the $75^{\text {th }}$ most relatively abundant protein. $n=4 \& 5$. 
Figure 2: Numbers of proteins increased and decreased with age in buttock and forearm skin. [A] Pie charts displaying the percentage of proteins increased, decreased and unchanged with age in the photoprotected buttock [i] and photoexposed dorsal forearm [ii]. [B] Venn diagram displaying the number of proteins in the buttock and forearm skin where fold change was $\leq 0.7$ or $\geq 1.5$ and $p \leq 0.05 . n=4-6$.

Figure 3: Changes in proteins with age organised by functional group. Fold change with age in proteins as grouped into molecular and cellular functions by IPA Ingenuity. Fold changes are plotted as $\log _{2}$ values. All changes exhibit $p$ values of 0.05 or less. 
Table I.

\begin{tabular}{|c|c|c|}
\hline & \multicolumn{2}{|c|}{ Gradient } \\
\hline Time $[\mathrm{min}]$ & $\% \mathrm{~A}$ & $\% \mathrm{~B}$ \\
\hline 0.0 & 97.0 & 3.0 \\
\hline 5.0 & 97.0 & 3.0 \\
\hline 30.0 & 73.0 & 27.0 \\
\hline 35.0 & 50.0 & 50.0 \\
\hline 36.0 & 0.0 & 100.0 \\
\hline 41.0 & 0.0 & 100.0 \\
\hline 42.0 & 97.0 & 3.0 \\
\hline 55.0 & 97.0 & 3.0 \\
\hline
\end{tabular}


Table II.

\begin{tabular}{|l|l|c|c|}
\hline \multicolumn{1}{|c}{ Identified Proteins } & Accession Number & Fold change & T-Test (P-Value) \\
\hline Keratin, type II cytoskeletal 6A & K2C6A_HUMAN & 648 & $\leq 0.01$ \\
\hline Coagulation factor XIII A & F13A_HUMAN & 5.7 & $\leq 0.01$ \\
\hline Filamin-A & FLNA_HUMAN & 4.0 & $\leq 0.05$ \\
\hline Fibrinogen alpha chain & FIBA_HUMAN & 3.0 & $\leq 0.05$ \\
\hline Serotransferrin OS & TRFE_HUMAN & 2.2 & $\leq 0.05$ \\
\hline Collagen alpha-3(VI) chain & CO6A3_HUMAN & 1.5 & $\leq 0.001$ \\
\hline Histone H1.2 & H12_HUMAN & 1.5 & $\leq 0.01$ \\
\hline Serum albumin & ALBU_HUMAN & 1.4 & $\leq 0.01$ \\
\hline Plakophilin-1 & PKP1_HUMAN & 0.8 & $\leq 0.05$ \\
\hline 40S ribosomal protein S18 & RS18_HUMAN & 0.5 & $\leq 0.05$ \\
\hline Heat shock protein beta-1 & HSPB1_HUMAN & 0.5 & $\leq 0.05$ \\
\hline 40S ribosomal protein S7 & RS7_HUMAN & 0.4 & $\leq 0.05$ \\
\hline Hemoglobin subunit alpha & HBA_HUMAN & 0.4 & $\leq 0.05$ \\
\hline Hemoglobin subunit beta & HBB_HUMAN & 0.4 & $\leq 0.05$ \\
\hline Adenine phosphoribosyltransferase & APT_HUMAN & 0.3 & $\leq 0.05$ \\
\hline Cathepsin D & CATD_HUMAN & 0.3 & $\leq 0.05$ \\
\hline GTP-binding nuclear protein Ran & RAN_HUMAN & 0.3 & $\leq 0.05$ \\
\hline Peroxiredoxin-1 & PRDX1_HUMAN & 0.3 & $\leq 0.01$ \\
\hline Profilin-1 & PROF1_HUMAN & 0.3 & $\leq 0.01$ \\
\hline Protein DJ-1 & PARK7_HUMAN & 0.3 & $\leq 0.05$ \\
\hline Ras-related C3 botulinum toxin substrate 1 & RAC1_HUMAN & 0.3 & $\leq 0.05$ \\
\hline 40S ribosomal protein S3 & RS3_HUMAN & 0.2 & $\leq 0.05$ \\
\hline 60S ribosomal protein L7a & RL7A_HUMAN & 0.2 & $\leq 0.01$ \\
\hline ADP/ATP translocase 2 & ADT2_HUMAN & 0.2 & $\leq 0.05$ \\
\hline NADH-cytochrome b5 reductase 1 & NB5R1_HUMAN & 0.2 & $\leq 0.01$ \\
\hline Phosphoglycerate mutase 1 & PGAM1_HUMAN & 0.2 & $\leq 0.01$ \\
\hline Proteasome subunit alpha type-1 & PSA1_HUMAN & 0.2 & $\leq 0.05$ \\
\hline Inositol monophosphatase 2 & IMPA2_HUMAN & $<0.001$ & $\leq 0.05$ \\
\hline Proteasome subunit alpha type-7-like & PSA7L_HUMAN & $<0.001$ & $\leq 0.05$ \\
\hline & & & \\
\hline
\end{tabular}


Table III.

\begin{tabular}{|c|c|c|c|}
\hline Identified Proteins & Accession Number & Fold change & T-Test (P-Value) \\
\hline Vitronectin & VTNC_HUMAN & 1000 & $\leq 0.001$ \\
\hline EH domain-containing protein 2 & EHD2_HUMAN & 110 & $\leq 0.05$ \\
\hline Hemoglobin subunit delta & HBD_HUMAN & 87 & $\leq 0.05$ \\
\hline Elastin & ELN_HUMAN & 49 & $\leq 0.05$ \\
\hline 2,4-dienoyl-CoA reductase, mitochondrial & DECR_HUMAN & 27 & $\leq 0.05$ \\
\hline Fibrinogen gamma chain & FIBG_HUMAN & 24 & $\leq 0.05$ \\
\hline Serum amyloid P-component & SAMP_HUMAN & 17 & $\leq 0.01$ \\
\hline Alcohol dehydrogenase $1 \mathrm{~A}$ & ADH1A_HUMAN & 15 & $\leq 0.001$ \\
\hline Hemoglobin subunit alpha & HBA_HUMAN & 14 & $\leq 0.05$ \\
\hline Transthyretin & TTHY_HUMAN & 13 & $\leq 0.05$ \\
\hline Clusterin & CLUS_HUMAN & 12 & $\leq 0.01$ \\
\hline Synaptic vesicle membrane protein VAT-1 homolog & VAT1_HUMAN & 9.7 & $\leq 0.01$ \\
\hline Histone H1.2 & H12_HUMAN & 7.1 & $\leq 0.05$ \\
\hline 60 S ribosomal protein $\mathrm{L} 34$ & RL34_HUMAN & 7.1 & $\leq 0.05$ \\
\hline Glycogen phosphorylase, brain form & PYGB_HUMAN & 4.6 & $\leq 0.05$ \\
\hline $40 \mathrm{~S}$ ribosomal protein $\mathrm{S} 20$ & RS20_HUMAN & 4.4 & $\leq 0.05$ \\
\hline Eukaryotic translation initiation factor 3 subunit $A$ & EIF3A_HUMAN & 4.3 & $\leq 0.05$ \\
\hline Small nuclear ribonucleoprotein Sm D3 & SMD3_HUMAN & 4.1 & $\leq 0.05$ \\
\hline Sideroflexin-3 & SFXN3_HUMAN & 4.1 & $\leq 0.05$ \\
\hline Protein S100-A4 & S10A4_HUMAN & 3.9 & $\leq 0.01$ \\
\hline Histone H4 & H4_HUMAN & 3.8 & $\leq 0.05$ \\
\hline Apolipoprotein A-II & APOA2_HUMAN & 3.8 & $\leq 0.05$ \\
\hline Myosin light polypeptide 6 & MYL6_HUMAN & 3.6 & $\leq 0.05$ \\
\hline $60 S$ ribosomal protein $\mathrm{L} 27$ & RL27_HUMAN & 3.6 & $\leq 0.01$ \\
\hline $60 S$ ribosomal protein $\mathrm{L} 22$ & RL22_HUMAN & 3.0 & $\leq 0.05$ \\
\hline Collagen alpha-1(I) chain & CO1A1_HUMAN & 2.8 & $\leq 0.05$ \\
\hline Spectrin alpha chain, non-erythrocytic 1 & SPTN1_HUMAN & 2.8 & $\leq 0.05$ \\
\hline Coagulation factor XIII A chain & F13A_HUMAN & 2.7 & $\leq 0.01$ \\
\hline Collagen alpha-2(VI) chain & CO6A2_HUMAN & 2.6 & $\leq 0.05$ \\
\hline Collagen alpha-2(I) chain & CO1A2_HUMAN & 2.4 & $\leq 0.05$ \\
\hline Heat shock protein HSP 90-alpha & HS90A_HUMAN & 2.4 & $\leq 0.01$ \\
\hline Clathrin heavy chain 1 & CLH1_HUMAN & 2.3 & $\leq 0.05$ \\
\hline Arginase-1 & ARGI1_HUMAN & 2.3 & $\leq 0.01$ \\
\hline Heat shock protein HSP 90-beta & HS90B_HUMAN & 2.2 & $\leq 0.01$ \\
\hline Transitional endoplasmic reticulum ATPase & TERA_HUMAN & 2.1 & $\leq 0.05$ \\
\hline Collagen alpha-1(VI) chain & CO6A1_HUMAN & 1.9 & $\leq 0.05$ \\
\hline Serum albumin & ALBU_HUMAN & 1.4 & $<0.05$ \\
\hline Keratin, type I cytoskeletal 14 & K1C14_HUMAN & 0.8 & $\leq 0.05$ \\
\hline Keratin, type I cytoskeletal 15 & K1C15_HUMAN & 0.8 & $\leq 0.05$ \\
\hline Tubulin beta chain & TBB5_HUMAN & 0.7 & $\leq 0.01$ \\
\hline Tubulin beta-4B chain & TBB4B_HUMAN & 0.7 & $\leq 0.05$ \\
\hline Tubulin beta- $4 A$ chain & TBB4A_HUMAN & 0.7 & $\leq 0.05$ \\
\hline Keratin, type II cytoskeletal 78 & K2C78_HUMAN & 0.4 & $\leq 0.05$ \\
\hline D-3-phosphoglycerate dehydrogenase & SERA_HUMAN & 0.4 & $\leq 0.01$ \\
\hline Heterogeneous nuclear ribonucleoproteins C1/C2 & HNRPC_HUMAN & 0.4 & $\leq 0.05$ \\
\hline Trifunctional enzyme subunit beta, mitochondrial & ECHB_HUMAN & 0.1 & $\leq 0.05$ \\
\hline Leucyl-tRNA synthetase, cytoplasmic & SYLC_HUMAN & $<0.001$ & $\leq 0.05$ \\
\hline Eukaryotic translation initiation factor 3 subunit $B$ & EIF3B_HUMAN & $<0.001$ & $\leq 0.05$ \\
\hline
\end{tabular}




\begin{tabular}{|c|c|c|c|c|c|c|}
\hline \multirow{4}{*}{ Table IV. } & Buttock & & & Forearm & & \\
\hline & & $A / Y$ & p-value & & $A / \gamma$ & p-value \\
\hline & 1 Stress response & & & 1 Stress response & & \\
\hline & Peroxiredoxin-1 & 0.3 & $\$ 0.01$ & Serum amyloid P-component & 17 & $\leq 0.01$ \\
\hline & Protein DJ-1 & 0.3 & $\leq 0.05$ & Clusterin & 12 & $\leq 0.01$ \\
\hline & & & & Synaptic vesicle membrane protein VAT- 1 homolog & 9.7 & s0.01 \\
\hline & & & & Heat shock protein HSP 90-alpha & 2.4 & $\leq 0.01$ \\
\hline & & & & Arginase-1 & 2.3 & $\leq 0.01$ \\
\hline & & & & Heat shock protein HSP 90 -beta & 2.2 & $\leq 0.01$ \\
\hline & & & & Transitional endoplasmic reticulum ATPase & 2.1 & 50.05 \\
\hline & & & & Leucyl-tRNA synthetase, cytoplasmic & 0.001 & $\leq 0.05$ \\
\hline & 2 Signalling & & & 2 Signalling & & \\
\hline & GTP-binding nuclear protein Ran & 0.3 & $\leq 0.05$ & Protein S100-A4 & 3.9 & $\leq 0.01$ \\
\hline & Peroxiredoxin-1 & 0.3 & $\leq 0.01$ & & & \\
\hline & Ras-related $\mathrm{C} 3$ botulinum toxin substrate & 0.3 & $\leq 0.05$ & & & \\
\hline & Proteasome subunit alpha type-1 & 0.2 & $\leq 0.05$ & & & \\
\hline & 3 Energy \& Metabolism & & & 3 Energy \& Metabolism & & \\
\hline & Adenine phosphoribosyltransferase & 0.3 & $\leq 0.05$ & 2,4-dienoyl-CoA reductase, mitochondrial & 27 & $\leq 0.05$ \\
\hline & ADP/ATP translocase 2 & 0.2 & $\leq 0.05$ & Alcohol dehydrogenase $1 \mathrm{~A}$ & 15 & s0.001 \\
\hline & NADH-cytochrome b5 reductase 1 & 0.2 & $\leq 0.01$ & Synaptic vesicle membrane protein VAT-1 homolog & 9.7 & $\leq 0.01$ \\
\hline & Phosphoglycerate mutase 1 & 0.2 & $\$ 0.01$ & Glycogen phosphorylase, brain form & 4.6 & $\leq 0.05$ \\
\hline & Inositol monophosphatase 2 & 0.001 & $\leq 0.05$ & Apolipoprotein A-ll & 3.8 & $\leq 0.05$ \\
\hline & & & & Spectrin alpha chain, non-erythrocytic 1 & 2.8 & $\leq 0.05$ \\
\hline & & & & Transitional endoplasmic reticulum ATPase & 2.1 & $\leq 0.05$ \\
\hline & & & & D-3-phosphoglycerate dehydrogenase & 0.4 & $\leq 0.01$ \\
\hline & & & & Trifunctional enzyme subunit beta, mitochondrial & 0.06 & $\leq 0.05$ \\
\hline & 4 Ubiquitin-proteasome \& associated sys & tems & & 4 Ubiquitin-proteasome \& associated systems & & \\
\hline & Cathepsin D & 0.3 & $\leq 0.01$ & EH domain-containing protein 2 & 110 & $\leq 0.05$ \\
\hline & Proteasome subunit alpha type-1 & 0.2 & $\leq 0.05$ & Clusterin & 12 & $\leq 0.01$ \\
\hline & Proteasome subunit alpha type-7-like & 0.001 & $\leq 0.05$ & Heat shock protein HSP 90-alpha & 2.4 & $\leq 0.01$ \\
\hline & & & & Heat shock protein HSP 90-beta & 2.2 & $\leq 0.01$ \\
\hline & & & & Transitional endoplasmic reticulum ATPase & 2.1 & $\leq 0.05$ \\
\hline & & & & Heterogeneous nuclear nibonucleoproteins C1/C2 & 0.4 & $\leq 0.05$ \\
\hline & 5 Immune-related & & & 5 Immune-related & & \\
\hline & Coagulation factor XIII & 5.7 & $\leq 0.01$ & Vitronectin & 1000 & $\leq 0.001$ \\
\hline & Filamin-A & 4 & 50.05 & EH domain-containing protein 2 & 110 & $\leq 0.05$ \\
\hline & Fibrinogen alpha chain & 3 & $\leq 0.05$ & Fibrinogen gamma chain & 24 & $\leq 0.05$ \\
\hline & Cathepsin D & 0.3 & $\leq 0.01$ & Serum amyloid P-component & 17 & $\leq 0.01$ \\
\hline & Peroxiredoxin-1 & 0.3 & $\leq 0.01$ & Clusterin & 12 & $\leq 0.01$ \\
\hline & Proflin-1 & 0.3 & $\leq 0.01$ & Apolipoprotein A-\|l & 3.8 & $\leq 0.05$ \\
\hline & Ras-related $\mathrm{C} 3$ botulinum toxin substrate & 0.3 & $\leq 0.05$ & Collagen alpha-1() chain & 2.8 & $\leq 0.05$ \\
\hline & Proteasome subunit alpha type-1 & 0.2 & $\leq 0.05$ & Spectrin alpha chain, non-erythrocytic 1 & 2.8 & $\leq 0.05$ \\
\hline & & & & Coagulation factor XVII & 2.7 & 50.01 \\
\hline & & & & Heat shock protein HSP 90-alpha & 2.4 & $\leq 0.01$ \\
\hline & & & & Arginase-1 & 2.3 & $\leq 0.01$ \\
\hline & & & & Heat shock protein HSP 90-beta & 2.2 & $\leq 0.01$ \\
\hline & & & & Collagen alpha-1(VI) chain & 1.9 & 50.05 \\
\hline & & & & Tubulin beta-4B chain & 0.7 & $\leq 0.05$ \\
\hline & 6 Protein Synthesis & & & 6 Protein Synthesis & & \\
\hline & 40 S ribosomal protein $\mathrm{S} 18$ & 0.5 & $\leq 0.05$ & $60 \mathrm{~S}$ ribosomal protein L34 & 7.1 & $\leq 0.05$ \\
\hline & 40 S ribosomal protein $\mathrm{S7}$ & 0.4 & 50.05 & $40 \mathrm{~S}$ ribosomal protein $\mathrm{S} 20$ & 4.4 & $\leq 0.05$ \\
\hline & 40 S ribosomal protein S3 & 0.2 & $\leq 0.05$ & Eukaryotic translation initiation factor 3 subunit A & 4.3 & $\leq 0.05$ \\
\hline & $60 S$ ribosomal protein L7a & 0.2 & $\leq 0.01$ & Small nuclear ribonucleoprotein Sm D3 & 4.1 & $\leq 0.05$ \\
\hline & & & & $60 \mathrm{~S}$ ribosomal protein $\mathrm{L} 27$ & 3.6 & $\leq 0.01$ \\
\hline & & & & $60 S$ ribosomal protein L22 & 3 & $\leq 0.05$ \\
\hline & & & & Heterogeneous nuclear ribonucleoproteins $\mathrm{C} 1 / \mathrm{C} 2$ & 0.4 & $\leq 0.05$ \\
\hline & & & & Eukaryotic translation initiation factor 3 subunit $B$ & 0.001 & $\leq 0.05$ \\
\hline & & & & Leucyl-tRNA synthetase, cytoplasmic & 0.001 & $\leq 0.05$ \\
\hline & 7 Structural & & & 7 Structural & & \\
\hline & Keratin, type II cytoskeletal 6A & 648 & $\leq 0.01$ & Vitronectin & 1000 & 50.001 \\
\hline & Coagulation factor XIII & 5.7 & $\leq 0.01$ & EH domain-containing protein 2 & 110 & $\leq 0.05$ \\
\hline & Filamin-A & 4 & $\leq 0.05$ & Elastin & 49 & $\leq 0.01$ \\
\hline & Fibrinogen alpha chain & 3 & $\leq 0.05$ & Fibrinogen gamma chain & 24 & $\leq 0.05$ \\
\hline & Collagen alpha-3(VI) chain & 1.5 & $\$ 0.0001$ & Myosin light polypeptide 6 & 3.6 & $\leq 0.05$ \\
\hline & Proflin-1 & 0.3 & $\leq 0.01$ & Collagen alpha-1() chain & 2.8 & $\leq 0.05$ \\
\hline & Ras-related $\mathrm{C} 3$ botulinum toxin substrate & 0.3 & $\leq 0.05$ & Spectrin alpha chain, non-erythrocytic 1 & 2.8 & $\leq 0.05$ \\
\hline & & & & Coagulation factor XIII & 2.7 & $\leq 0.01$ \\
\hline & & & & Collagen alpha-2(VI) chain & 2.6 & $\leq 0.05$ \\
\hline & & & & Collagen alpha-2(i) chain & 2.4 & $\leq 0.05$ \\
\hline & & & & Collagen alpha-1(VI) chain & 1.9 & $\leq 0.05$ \\
\hline & & & & Tubulin beta-4A chain & 0.7 & $\leq 0.05$ \\
\hline & & & & Tubulin beta $4 B$ chain & 0.7 & $\leq 0.05$ \\
\hline & & & & Keratin, type II cytoskeletal 78 & 0.4 & $\leq 0.05$ \\
\hline & 8 Transportation \& metal binding & & & 8 Transportation \& metal binding & & \\
\hline & Coagulation factor XII & 5.7 & 50.01 & EH domain-containing protein 2 & 110 & $\leq 0.05$ \\
\hline & Fibrinogen alpha chain & 3 & $\leq 0.05$ & Hemoglobin subunit delta & 87 & $\leq 0.05$ \\
\hline & Hemoglobin subunit alpha & 0.4 & 50.05 & Fibrinogen gamma chain & 24 & $\leq 0.05$ \\
\hline & Hemoglobin subunit beta & 0.4 & $\leq 0.05$ & Serum amyloid P-component & 17 & $\leq 0.01$ \\
\hline & Inositol monophos phatase 2 & 0.001 & 50.05 & Hemoglobin subunit alpha & 14 & $\leq 0.05$ \\
\hline & & & & Transthyretin & 13 & $\leq 0.05$ \\
\hline & & & & Synaptic vesicle membrane protein VAT- 1 homolog & 9.7 & $\leq 0.01$ \\
\hline & & & & Sideroflexin-3 & 4.1 & $\leq 0.05$ \\
\hline & & & & Protein S100-A4 & 3.9 & $\leq 0.01$ \\
\hline & & & & Collagen alpha-1(l) chain & 2.8 & $\leq 0.05$ \\
\hline & & & & Spectrin alpha chain, non-erythrocytic 1 & 2.8 & $\leq 0.05$ \\
\hline & & & & Coagulation factor XIII & 2.7 & $\leq 0.01$ \\
\hline & & & & Clathrin heavy chain 1 & 2.3 & $\leq 0.05$ \\
\hline & 9 Histone & & & 9 Histone & & \\
\hline & Histone $\mathrm{H} 1.2$ & 1.5 & $\leq 0.01$ & Histone H1.2 & 7.1 & $\leq 0.05$ \\
\hline & & & & Histone H4 & 3.8 & $\leq 0.05$ \\
\hline
\end{tabular}




\begin{tabular}{|c|c|c|c|c|c|c|c|c|}
\hline & \multicolumn{4}{|c|}{ Buttock } & & Forearm & & \\
\hline & & & $A / r$ & p-value & & & $A / Y$ & $p$-value \\
\hline lable V. & 1 Cell dea & nd survival: & & & 1 Cell death a & and survival: & & \\
\hline & FLNA & Filamin-A & 4 & $\leq 0.05$ & VTN & Vitronectin & 1000 & $\leq 0.01$ \\
\hline & TF & Serotransferrin & 2.2 & $\leq 0.05$ & CLU & Clusterin & 12 & $\leq 0.01$ \\
\hline & HSPB1 & Heat shock protein beta- 1 & 0.5 & $\leq 0.05$ & EIF3A & Eukaryotic translation initiation factor 3 subunit A & 4.3 & $\$ 0.05$ \\
\hline & HBB & Hemoglobin subunit beta & 0.4 & $\leq 0.05$ & S100A4 & Protein S100-A4 & 3.9 & $\leq 0.01$ \\
\hline & PARK7 & Protein DJ-1 & 0.3 & $\leq 0.05$ & RPL27 & 60 s ribosomal protein L27 & 3.6 & $\leq 0.01$ \\
\hline & RAC1 & Ras-related C 3 botulinum toxin substrate 1 & 0.3 & $\leq 0.05$ & Col1A1 & Collagen alpha-1(l) chain & 2.8 & 50.05 \\
\hline & PSMA1 & Proteasome subunit alpha type-1 & 0.2 & $\leq 0.05$ & HSP9OAB1 & Heat shock protein HSP 90-beta & 2.2 & $\leq 0.01$ \\
\hline & & & & & VCP & Transitional endoplasmic reticulum ATPase & 2.1 & $\leq 0.05$ \\
\hline & & & & & TUBBAA & Tubulin beta- $4 \mathrm{~A}$ chain & 0.7 & $\$ 0.05$ \\
\hline & 2 Lipid me & olism: & & & 2 Lipid metab & bolism: & & \\
\hline & & & & & VTN & Vitronectin & 1000 & $\leq 0.01$ \\
\hline & & & & & CLU & Clusterin & 12 & $\leq 0.01$ \\
\hline & & & & & APOA2 & Apolipoprotein A-II & 3.8 & $\$ 0.05$ \\
\hline & 3 Cellular & embly and organisation: & & & 3 Cellular ass & isembly and organisation: & & \\
\hline & KRTGA & Keratin, type II cytoskeletal 6A & 648 & $\leq 0.01$ & VTN & Vitronectin & 1000 & $\leq 0.01$ \\
\hline & FLNA & Filamin-A & 4 & $\leq 0.05$ & APCS & Serum amyloid $\mathrm{P}$-component & 17 & $\leq 0.01$ \\
\hline & Col6A3 & Collagen alpha-3(VI) chain & 1.5 & $<0.001$ & $\pi R$ & Transthyretin & 13 & 50.05 \\
\hline & HSPB1 & Heat shock protein beta- 1 & 0.5 & $\leq 0.05$ & S100A4 & Protein S100-A4 & 3.9 & $\leq 0.01$ \\
\hline & PFN1 & Profilin-1 & 0.3 & $\leq 0.01$ & SPTAN1 & Spectrin alpha chain, non-erythrocytic 1 & 2.8 & $\$ 0.05$ \\
\hline & RAN & GTP-binding nuclear protein Ran & 0.3 & $\leq 0.05$ & & & & \\
\hline & RAC1 & Ras-related $\mathrm{C} 3$ botulinum toxin substrate 1 & 0.3 & $\leq 0.05$ & & & & \\
\hline & RPS3 & 405 ribosomal protein $\$ 3$ & 0.2 & $\leq 0.05$ & & & & \\
\hline & 4 Cellular & wth and proliferation: & & & 4 Cellular gro & owth and proliferation: & & \\
\hline & Rac1 & Ras-related $C 3$ botulinum toxin substrate 1 & 0.3 & $\leq 0.05$ & $\pi R$ & Transthyretin & 13 & $\leq 0.05$ \\
\hline & & & & & Clu & Clusterin & 12 & $\leq 0.01$ \\
\hline & & & & & HSP9OAA1 & Heat shock protein HSP 90-alpha & 2.4 & $\leq 0.01$ \\
\hline & & & & & HSP90AB1 & Heat shock protein HSP 90-beta & 2.2 & $\leq 0.01$ \\
\hline & 5 Cellular & vement: & & & 5 Cellular mo & ovement: & & \\
\hline & FLNA & Filamin-A & 4 & $\leq 0.05$ & VTN & Vitronectin & 1000 & $\leq 0.01$ \\
\hline & FGA & Fibrinogen alpha chain & 3 & $\leq 0.05$ & S100A4 & Protein S100-A4 & 3.9 & $\leq 0.01$ \\
\hline & HSPB1 & Heat shock protein beta- 1 & 0.5 & $\leq 0.05$ & Col1A1 & Collagen alpha-1(I) chain & 2.8 & $\leq 0.05$ \\
\hline & RAC1 & Ras-related $\mathrm{C} 3$ botulinum toxin substrate 1 & 0.3 & $\leq 0.05$ & & & & \\
\hline & 6 Cell mor & logy: & & & 6 Cell morph & ology: & & \\
\hline & FLNA & Filamin-A & 4 & $\leq 0.05$ & VTN & Vitronectin & 1000 & $\leq 0.01$ \\
\hline & PFN1 & Profilin-1 & 0.3 & $\leq 0.01$ & clu & Clusterin & 12 & $\leq 0.01$ \\
\hline & RAC1 & Ras-related C 3 botulinum toxin substrate 1 & 0.3 & $\leq 0.05$ & hsp90AA1 & Heat shock protein HSP 90-alpha & 2.4 & $\leq 0.01$ \\
\hline & 7 Cell-to- $-c$ & signalling: & & & 7 Cell-to-cell & | signalling: & & \\
\hline & FLNA & Filamin-A & 4 & $\leq 0.05$ & VTN & Vitronectin & 1000 & $\leq 0.01$ \\
\hline & FGA & Fibrinogen alpha chain & 3 & $\leq 0.05$ & APCS & Serum amyloid $\mathrm{P}$-component & 17 & $\leq 0.01$ \\
\hline & HSPB1 & Heat shock protein beta-1 & 0.5 & $\leq 0.05$ & & & & \\
\hline & HBB & Hemoglobin subunit beta & 0.4 & $\leq 0.05$ & & & & \\
\hline & RAC1 & Ras-related C 3 botulinum toxin substrate 1 & 0.3 & $\leq 0.05$ & & & & \\
\hline & CTSD & Cathepsin D & 0.3 & $\leq 0.05$ & & & & \\
\hline & 8 Post-tra & Itional modification & & & 8 Post-transla & lational modification: & & \\
\hline & & & & & APCS & Serum amyloid P-component & 17 & $\$ 0.01$ \\
\hline & & & & & APOA2 & Apolipoprotein A-II & 3.8 & $\leq 0.05$ \\
\hline & & & & & HSP9OAA1 & Heat shock protein HSP 90-alpha & 2.4 & 50.01 \\
\hline & 9 Hair and & n devlopment \& function: & & & 9 Hair and ski & cin devlopment \& function: & & \\
\hline & FLNA & Filamin-A & 4 & $\leq 0.05$ & $\pi R$ & Transthyretin & 13 & $\leq 0.05$ \\
\hline & & & & & CLU & Clusterin & 12 & $\leq 0.01$ \\
\hline & & & & & COL1A1 & Collagen alpha-1(I) chain & 2.8 & $\leq 0.05$ \\
\hline & & & & & COL1A2 & Collagen alpha-2(l) chain & 2.4 & $\leq 0.05$ \\
\hline & & & & & HSP9OAA1 & Heat shock protein HSP 90-alpha & 2.4 & $\$ 0.01$ \\
\hline & & & & & HSP9OAB1 & Heat shock protein HSP 90-beta & 2.2 & $\leq 0.01$ \\
\hline & 10 Gene ex & ssion: & & & 10 Gene expre & ession: & & \\
\hline & FLNA & Filamin-A & 4 & $\leq 0.05$ & & & & \\
\hline & TF & Serotransferrin & 2.2 & 50.05 & & & & \\
\hline & HBB & Hemoglobin subunit beta & 0.4 & $\leq 0.05$ & & & & \\
\hline & PRDX1 & Peroxiredoxin-1 & 0.3 & $\leq 0.01$ & & & & \\
\hline & RAC1 & Ras-related $C 3$ botulinum toxin substrate 1 & 0.3 & $\leq 0.05$ & & & & \\
\hline & PARK7 & Protein DJ-1 & 0.3 & $\leq 0.05$ & & & & \\
\hline & RPS3 & 405 ribosomal protein $\$ 3$ & 0.2 & $\leq 0.05$ & & & & \\
\hline & 11 Free rad & scavenging: & & & 11 Free radical & scavenging & & \\
\hline & HSPB1 & Heat shock protein beta- 1 & 0.5 & 50.05 & & & & \\
\hline & HBB & Hemoglobin subunit beta & 0.4 & $\leq 0.05$ & & & & \\
\hline & PARK7 & Protein DJ-1 & 0.3 & $\leq 0.05$ & & & & \\
\hline & PRDX1 & Peroxiredoxin-1 & 0.3 & 50.01 & & & & \\
\hline & RAC1 & Ras-related $\mathrm{C} 3$ botulinum toxin substrate 1 & 0.3 & $\leq 0.05$ & & & & \\
\hline & 12 Protein & ethsis: & & & 12 Protein syn & nethsis & & \\
\hline & FLNA & Filamin-A & 4 & $\leq 0.05$ & & & & \\
\hline & FGA & Fibrinogen alpha chain & 3 & $\leq 0.05$ & & & & \\
\hline & TF & Serotransferrin & 2.2 & $\leq 0.05$ & & & & \\
\hline & HSPB1 & Heat shock protein beta- 1 & 0.5 & $\leq 0.05$ & & & & \\
\hline & RPS7 & 405 ribosomal protein 57 & 0.4 & $\leq 0.05$ & & & & \\
\hline & CTSD & Cathepsin D & 0.3 & 50.05 & & & & \\
\hline & PFN1 & Profilin-1 & 0.3 & $\leq 0.01$ & & & & \\
\hline & PARK7 & Protein DJ-1 & 0.3 & $\leq 0.05$ & & & & \\
\hline & RAC1 & Ras-related $\mathrm{C} 3$ botulinum toxin substrate 1 & 0.3 & $\leq 0.05$ & & & & \\
\hline & RPS3 & 405 ribosomal protein $\mathrm{S} 3$ & 0.2 & $\leq 0.05$ & & & & \\
\hline & 13 Protein & radation: & & & 13 Protein deg & gradation & & \\
\hline & FLNA & Filamin-A & 4 & $\leq 0.05$ & & & & \\
\hline & TF & Serotransferrin & 2.2 & $\leq 0.05$ & & & & \\
\hline & CTSD & Cathepsin D & 0.3 & $\leq 0.05$ & & & & \\
\hline & PFN1 & Profilin-1 & 0.3 & $\leq 0.01$ & & & & \\
\hline & PARK7 & Protein DJ-1 & 0.3 & $\leq 0.05$ & & & & \\
\hline
\end{tabular}


A (i) Protein abundance in young forearm skin compared with young buttock skin

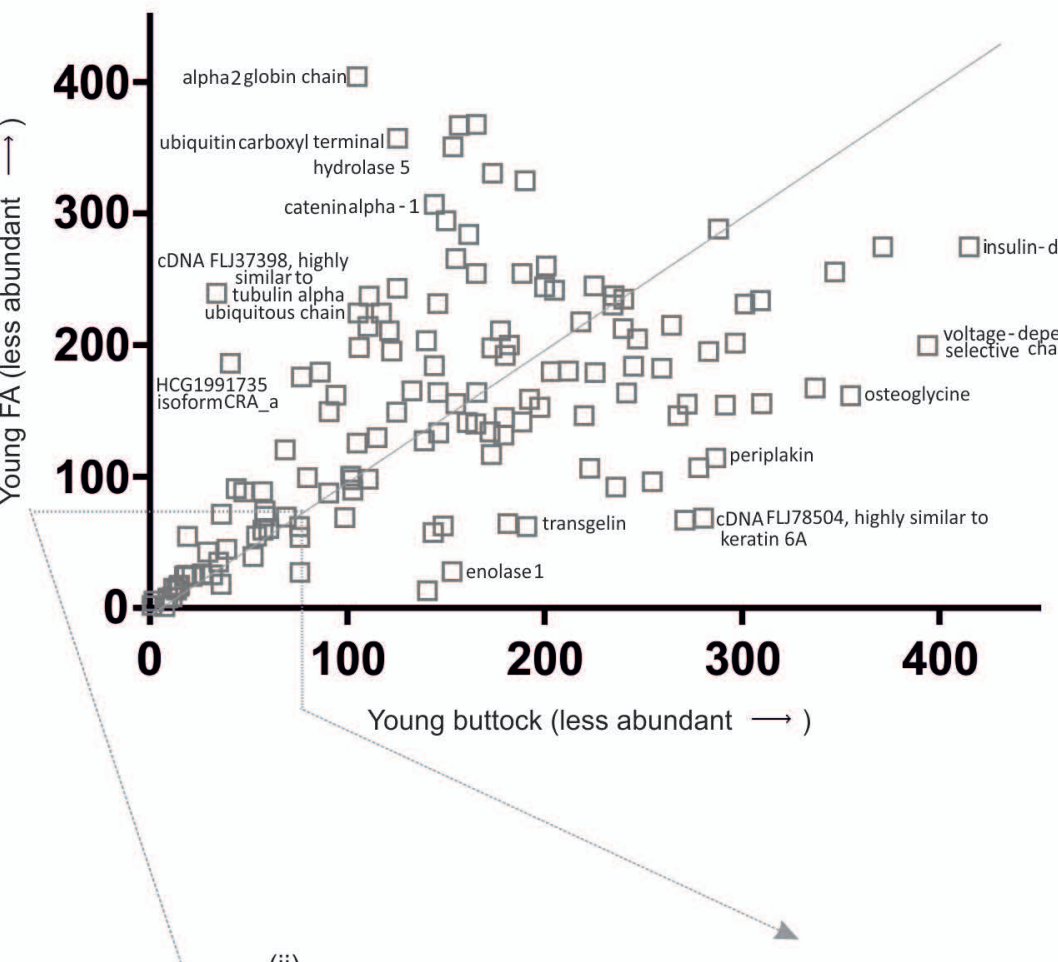

(ii)

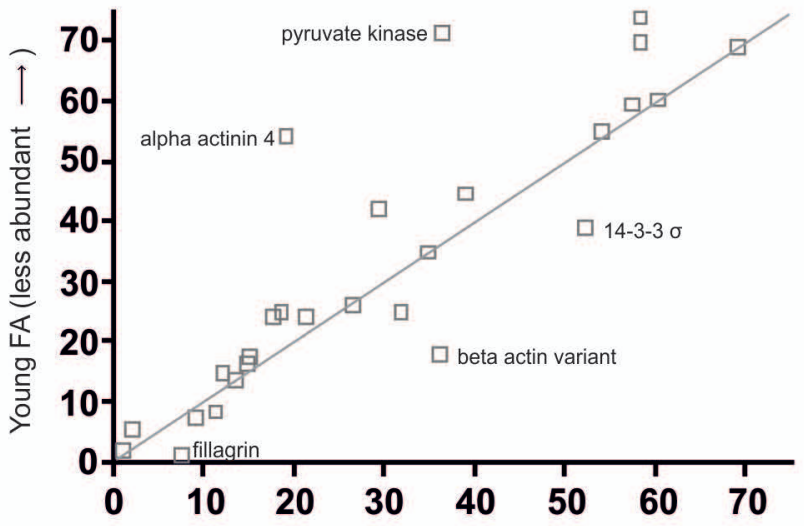

Young buttock (less abundant $\longrightarrow$ ) 
A
(i)

\section{Buttock}

(ii)

\section{Forearm}

Increased in aged Decreased in aged No change

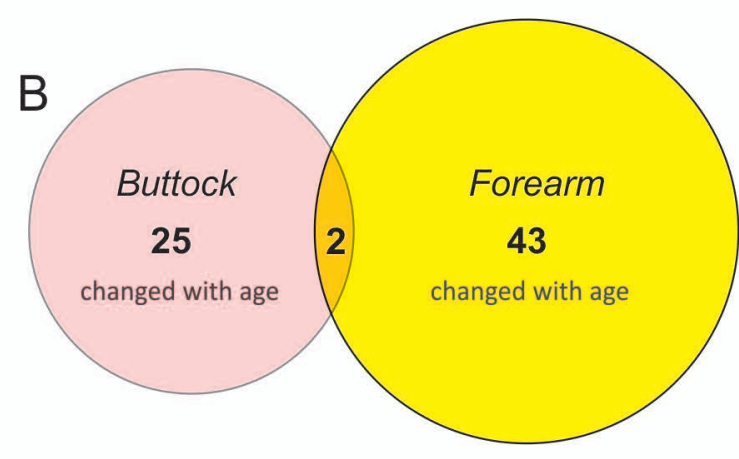


Adenylate kinase 2, mitochondrial

Alcohol dehydrogenase IB (Class I), beta polypeptide, isoform CRA_a Alpha-2 globin chain

Alpha-actinin-4

Amyloid $\mathrm{P}$ component, serum

Annexin (Fragment)

APEX nuclease

Apolipoprotein A-I, is oform CRA_a

Arginase-1

ATP synthase subunit alpha

ATP-dependent RNA helicase DDX3X

Beta 5-tubulin

Beta actin variant (Fragment)

Biglycan preproprotein variant (Fragment)

Brain specific protein, isoform CRA_a

Calmodulin-like skin protein variant

(Fragment)

Calnexin

Carbonyl reductase [NADPH] 1

Caspase 14, a poptosis-related cysteine

peptidase

Catenin alpha-1

Cathepsin D (Lysosomal aspartyl peptidase)

is oform CRA_a

Caveolin

cDNA FU37398 fis, clone BRAMY2027467,

highly similar to Tubulin alpha-ubiquitous

chain

cDNA FL44920 fis, clone BRAMY3011501,

highly similar to Heterogeneous nuclear ribonucleoprotein U

Buttock

259

Forearm

183

\begin{tabular}{l|l}
52 & 39
\end{tabular}

$268 \quad 147$

242

147

165

164

165

140

166

164

235

231

288

288

105

404

19

54

255

96

141

13

189

255

111

98

192

159

57

89

106

198

146

\begin{tabular}{|c|c|}
\hline 36 & 18 \\
\hline 117 & 224 \\
\hline 111 & 214 \\
\hline
\end{tabular}

155

157

266

57

367

60

103

90

144

307

198

153

180

145

cDNA FU75422, highly similar to Homo

sapiens capping protein (actin filament)

muscle Z-line, alpha 1, mRNA

cDNA FU78244, highly similar to Homo

sapiens eukaryotic translation initiation

factor 4A, is oform 1 (EIF4A1), mRNA

cDNA FU78504, highly similar to Homo

sapiens keratin 6A (KRT6A), mRNA

cDNA FU78674, highly similar to Homo

sapiens desmocollin type 4

cDNA, FL94198, highly similar to Homo

sapiens carboxypeptidase $\mathrm{A} 3$ (mast cell)

(CPA3), mRNA

cDNA, FL94268, highly similar to Homo

sapiens histone 1, H1e (HIST1H1E), mRNA

cDNA, FU94551

cDNA, FL95650, highly similar to Homo

sapiens karyopherin (importin) beta 1

(KPNB1), mRNA

Chaperonin containing TCP1, subunit 2 (Beta)

isoform CRA_b

Chloride intracellular channel protein

Chromosome 7 open reading frame 24

Clathrin heavy chain

Cofilin 1 (Non-muscle), is oform CRA_b

Collagen alpha-1(I) chain

Core histone macro-H2A.1

Cytoplasmic dynein 1 heavy chain 1

DCN protein

Desmocollin 1

44

91

275

371
Name

Relative abundance (N; $0 \mathrm{dp})$

(ordered according to buttock most abundant)

Desmoplakin

Keratin 1

Filaggrin

Neuroblast differentiation-associated

protein AHNAK

Collagen alpha-1(I) chain

Serum albumin

Vimentin

Epiplakin

Junction plakoglobin, isoform CRA_a

Buttock

1

2

8

9

11

12

14

15

15

Plectin

Periostin, osteoblast specific factor, is oform

CRA_c

Alpha-actinin-4

Prelamin-A/C

Desmoglein-1

DCN protein

Plakophilin 1 (Ectodermal dysplasia/skin

fragility syndrome), isoform CRA_a

cDNA FL37398 fis, clone BRAMY2027467,

highly similar to Tubulin alpha-ubiquitous

chain

Ezrin

Beta actin variant (Fragment)

Pyruvate kinase

Gelsolin

HCG1991735, isoform CRA_a

cDNA FL78674, highly similar to Homo

sapiens desmocollin type 4

cDNA, FU94268, highly similar to Homo

sapiens histone $1, \mathrm{H} 1 \mathrm{e}$ (HIST1H1E), mRNA

14-3-3 protein sigma

Lumican

ATP synthase subunit alpha

Carbonyl reductase [NADPH] 1

Nucleolin, isoform CRA_b

PRELP protein (Fragment)

Transferrin variant (Fragment)

High-mobility group box 1 , isoform CRA_a

Desmocollin 1

L-lactate dehydrogenase

Elongation factor 1-alpha

Fructose-bisphosphate aldolase

Glyceraldehyde-3-phosphate dehydrogenase

Envoplakin

Peroxiredoxin-1

Suprabasin

Serpin peptidase inhibitor, clade B

(Ovalbumin), member 5, isoform CRA b

Heat shock protein 90kDa alpha (Cytosolic),

class B member 1, isoform CRA_a

Cytoplasmic dynein 1 heavy chain 1

Hemoglobin, beta

Profilin-1

Peroxidoxin 6

Caspase 14, apoptosis-related cysteine

peptidase

58

70

58

74

60

69

69

120

69

76

62

76

76

Alpha-2 globin chain 


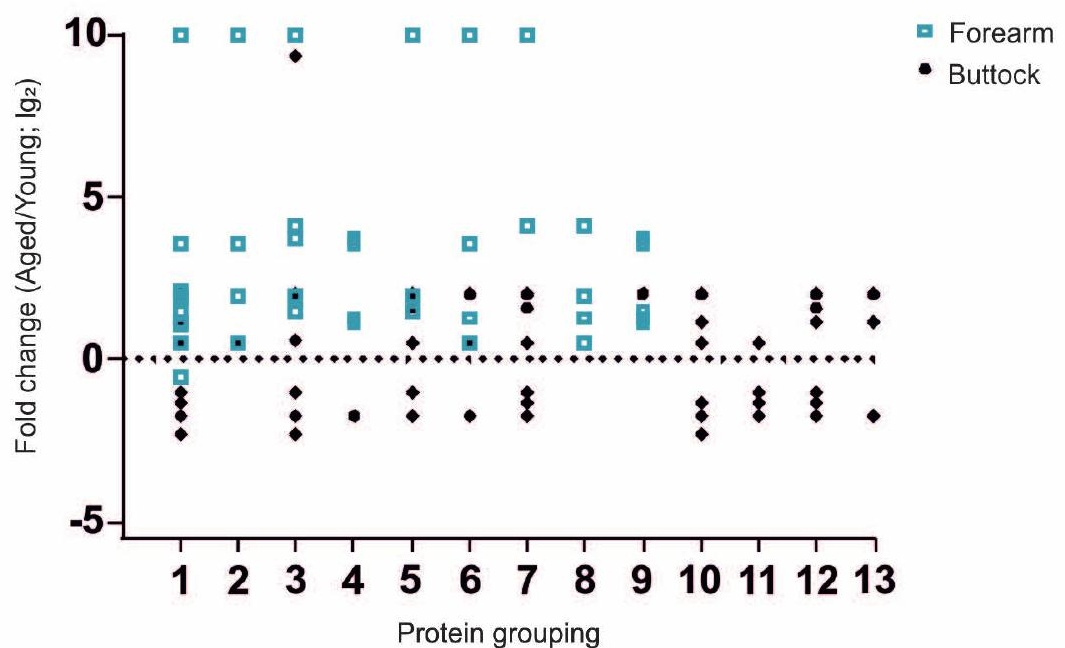

1 Cell death and survival 2 Lipid metabolism

3 Cellular assembly and organisation 4 Cellular growth and proliferation 5 Cellular movement 6 Cell morphology 7 Cell-to-cell signalling 8 Post-translational modification 9 Hair and skin devlopment \& function 10 Gene expression 11 Free radical scavenging 12 Protein synethsis 13 Protein degradation Protein grouping 
Adenylate kinase 2, mitochondrial

Alcohol dehydrogenase IB (Class I), beta polypeptide, isoform CRA_a Alpha-2 globin chain

Alpha-actinin-4

Amyloid $\mathrm{P}$ component, serum

Annexin (Fragment)

APEX nuclease

Apolipoprotein A-I, is oform CRA_a

Arginase-1

ATP synthase subunit alpha

ATP-dependent RNA helicase DDX3X

Beta 5-tubulin

Beta actin variant (Fragment)

Biglycan preproprotein variant (Fragment)

Brain specific protein, isoform CRA_a

Calmodulin-like skin protein variant

(Fragment)

Calnexin

Carbonyl reductase [NADPH] 1

Caspase 14, a poptosis-related cysteine

peptidase

Catenin alpha-1

Cathepsin D (Lysosomal aspartyl peptidase)

is oform CRA_a

Caveolin

cDNA FU37398 fis, clone BRAMY2027467,

highly similar to Tubulin alpha-ubiquitous

chain

cDNA FL44920 fis, clone BRAMY3011501,

highly similar to Heterogeneous nuclear ribonucleoprotein U

Buttock

259

Forearm

183

\begin{tabular}{l|l}
52 & 39
\end{tabular}

$268 \quad 147$

242

147

165

164

165

140

166

164

235

231

288

288

105

404

19

54

255

96

141

13

189

255

111

98

192

159

57

89

106

198

146

\begin{tabular}{|c|c|}
\hline 36 & 18 \\
\hline 117 & 224 \\
\hline 111 & 214 \\
\hline
\end{tabular}

155

157

266

57

367

60

103

90

144

307

198

153

180

145

cDNA FU75422, highly similar to Homo

sapiens capping protein (actin filament)

muscle Z-line, alpha 1, mRNA

cDNA FU78244, highly similar to Homo

sapiens eukaryotic translation initiation

factor 4A, is oform 1 (EIF4A1), mRNA

cDNA FU78504, highly similar to Homo

sapiens keratin 6A (KRT6A), mRNA

cDNA FU78674, highly similar to Homo

sapiens desmocollin type 4

cDNA, FL94198, highly similar to Homo

sapiens carboxypeptidase $\mathrm{A} 3$ (mast cell)

(CPA3), mRNA

cDNA, FL94268, highly similar to Homo

sapiens histone 1, H1e (HIST1H1E), mRNA

cDNA, FU94551

cDNA, FL95650, highly similar to Homo

sapiens karyopherin (importin) beta 1

(KPNB1), mRNA

Chaperonin containing TCP1, subunit 2 (Beta)

isoform CRA_b

Chloride intracellular channel protein

Chromosome 7 open reading frame 24

Clathrin heavy chain

Cofilin 1 (Non-muscle), is oform CRA_b

Collagen alpha-1(I) chain

Core histone macro-H2A.1

Cytoplasmic dynein 1 heavy chain 1

DCN protein

Desmocollin 1

44

91

275

371
Name

Relative abundance (N; $0 \mathrm{dp})$

(ordered according to buttock most abundant)

Desmoplakin

Keratin 1

Filaggrin

Neuroblast differentiation-associated

protein AHNAK

Collagen alpha-1(I) chain

Serum albumin

Vimentin

Epiplakin

Junction plakoglobin, isoform CRA_a

Buttock

1

2

8

9

11

12

14

15

15

Plectin

Periostin, osteoblast specific factor, is oform

CRA_c

Alpha-actinin-4

Prelamin-A/C

Desmoglein-1

DCN protein

Plakophilin 1 (Ectodermal dysplasia/skin

fragility syndrome), isoform CRA_a

cDNA FL37398 fis, clone BRAMY2027467,

highly similar to Tubulin alpha-ubiquitous

chain

Ezrin

Beta actin variant (Fragment)

Pyruvate kinase

Gelsolin

HCG1991735, isoform CRA_a

cDNA FL78674, highly similar to Homo

sapiens desmocollin type 4

cDNA, FU94268, highly similar to Homo

sapiens histone $1, \mathrm{H} 1 \mathrm{e}$ (HIST1H1E), mRNA

14-3-3 protein sigma

Lumican

ATP synthase subunit alpha

Carbonyl reductase [NADPH] 1

Nucleolin, isoform CRA_b

PRELP protein (Fragment)

Transferrin variant (Fragment)

High-mobility group box 1 , isoform CRA_a

Desmocollin 1

L-lactate dehydrogenase

Elongation factor 1-alpha

Fructose-bisphosphate aldolase

Glyceraldehyde-3-phosphate dehydrogenase

Envoplakin

Peroxiredoxin-1

Suprabasin

Serpin peptidase inhibitor, clade B

(Ovalbumin), member 5, isoform CRA b

Heat shock protein 90kDa alpha (Cytosolic),

class B member 1, isoform CRA_a

Cytoplasmic dynein 1 heavy chain 1

Hemoglobin, beta

Profilin-1

Peroxidoxin 6

Caspase 14, apoptosis-related cysteine

peptidase

58

70

58

74

60

69

69

120

69

76

62

76

76

Alpha-2 globin chain 


\begin{tabular}{|c|c|}
\hline 27 & 26 \\
\hline 1 & 2 \\
\hline 272 & 155 \\
\hline 16 & 54 \\
\hline 77 & 28 \\
\hline 15 & 176 \\
\hline 283 & 17 \\
\hline 35 & 195 \\
\hline 8 & 35 \\
\hline 292 & 1 \\
\hline 76 & 154 \\
\hline 155 & 53 \\
\hline 200 & 155 \\
\hline 39 & 244 \\
\hline 247 & 45 \\
\hline 150 & 205 \\
\hline
\end{tabular}

Zinc-alpha-2-glycoprotein

105

Triosephosphate isomerase

106

ATP-dependent RNA helicase DDX3X

Apolipoprotein A-I, is oform CRA_a

Brain specific protein, isoform CRA_a

Phosphoglycerate mutase 1 (Brain)

cDNA, FU95650, highly similar to Homo

sapiens karyopherin (importin) beta 1

(KPNB1), mRNA

Biglycan preproprotein variant (Fragment)

Protein AHNAK2

MHC class I antigen (Fragment)

Myosin light polypeptide 6

Ribosomal protein L11, isoform CRA_b

Ubiquitin-activating enzyme E1 (A1S9T and

106

111

111

111

125

58

BN75 temperature sensitivity

115

117

121

123

125

125

198

98

14

complementing), is oform CRA_a

GTP-binding nuclear protein Ran

Prohibitin-2

HNRPK protein

Annexin (Fragment)

\begin{tabular}{c|c}
76 & 27 \\
\hline 133 & 165 \\
\hline
\end{tabular}

Tripartite motif protein TRIM29 isoform

alpha variant (Fragment)

\begin{tabular}{c|r}
190 & 325 \\
\hline 41 & 186 \\
\hline
\end{tabular}

HCG1991735, is oform CRA_a

Heat shock protein 90kDa alpha (Cytosolic),

class B member 1, isoform CRA_a

150

\begin{tabular}{|c|c|}
\hline 91 & 150 \\
\hline 99 & 69 \\
\hline 165 & 255 \\
\hline 205 & 242 \\
\hline
\end{tabular}

Catenin alpha-1

Spectrin al pha chain, non-erythrocytic 1

NADH-cytochrome b5 reductase 1

Beta 5-tubulin

Heterogeneous nuclear ribonucleoprotein A1

Hemoglobin, beta

Heparin-binding protein $\mathrm{HBp} 15$

Heterochromatin protein 1-binding protein 3

Phosphoglycerate kinase

Glutathione S-transferase mu 1 is oform B

(Fragment)

133

146

Enolase 1, (Alpha), is oform CRA_a

cDNA, FL94551

Calmodulin-like skin protein variant

(Fragment)

\begin{tabular}{|c|c}
\hline 69 & 120 \\
\hline 264 & 215 \\
\hline
\end{tabular}

\begin{tabular}{l|l}
140 & 203 \\
\hline
\end{tabular}

\begin{tabular}{l|l}
1415 & 275 \\
\hline 165 & 368
\end{tabular}

165

368

\begin{tabular}{l|l}
15 & 18 \\
\hline
\end{tabular}

\begin{tabular}{l|l}
2 & 6 \\
\hline
\end{tabular}

\begin{tabular}{l|l}
76 & 62 \\
\hline 54 & 55
\end{tabular}

\begin{tabular}{l|l}
54 & 55 \\
\hline 173 & 117
\end{tabular}

173

55

162

117

\begin{tabular}{l|l}
162 & 284 \\
\hline 123 & 196 \\
\hline
\end{tabular}

MHC class I antigen (Fragment)

Mitochondrial heat shock $60 \mathrm{kD}$ protein 1

variant 1

225

245

\begin{tabular}{l|r}
125 & 149 \\
\hline 146 & 232
\end{tabular}

146

232

NADH-cytochrome b5 reductase 1

Nascent polypeptide-associated complex

subunit al pha, muscle-specific form

Neuroblast differentiation-associated protein

AHNAK

Nucleolin, is oform CRA_b

Nucleoside diphosphate kinase

Osteoglycin OG

Peptidyl-prolyl cis-trans isomerase B

Periostin, osteoblast specific factor, is oform

CRA_C

226

179

Galectin

Calnexin

Protein disulfide-isomerase

Mast cell tryptase beta III

Actin-related protein 2/3 complex subunit 3

Heparin-binding protein $\mathrm{HBp} 15$

Integrin alpha-6

Adenine phosphoribosyltransferase

(Fragment)

Nucleoside diphosphate kinase

Malate dehydrogenase

Transforming growth factor, beta-induced,

$68 \mathrm{kDa}$ variant (Fragment)

126

133

139

140

141

144

144

144

146

146

146

149

150

153

154

155

155

157

161

162

165

165

165

166

172

173

173

Core histone macro-H2A.1

Protein IGKV3-11

Cofilin 1 (Non-muscle), isoform CRA_b

Caveolin

Polypyrimidine tract binding protein 1 ,

is oform CRA_b

Peptidyl-prolyl cis-trans isomerase $B$

cDNA FL75422, highly similar to Homo

sapiens capping protein (actin filament)

muscle Z-line, alpha 1, mRNA

APEX nuclease

Hexokinase

H.sapiens ras-related Hrab6 protein

Transketolase

\begin{tabular}{l|l}
179 & 132
\end{tabular}

\begin{tabular}{l|l}
1700 & 145
\end{tabular}


Peroxidoxin 6

Peroxiredoxin-1

Phosphoglycerate kinase

Phosphoglycerate mutase 1 (Brain)

Plakophilin 1 (Ectodermal dysplasia/skin

fragility syndrome), is oform CRA_a

Plectin

PMVK protein (Fragment)

Polypyrimidine tract binding protein 1 ,

is oform CRA_b

Prelamin-A/C

PRELP protein (Fragment)

Profilin-1

Prohibitin-2

Proteasome subunit alpha type (Fragment)

Protein AHNAK2

Protein disulfide-isomerase

Protein IGKV3-11

PSME1 protein (Fragment)

Pyruvate dehydrogenase E1 component

subunit beta, mitochondrial

Pyruvate kinase

RAB14, member RAS oncogene family, is oform

CRA_a

Ribosomal protein L11, is oform CRA_b

Serpin peptidase inhibitor, clade $B$

(Ovalbumin), member 5 , is oform CRA_b

Serum albumin

SFPQ protein (Fragment)

SLC25A5 protein (Fragment)

Spectrin alpha chain, non-erythrocytic 1

Superoxide dismutase [Cu-Zn]

Suprabasin

Tenascin

Transaldolase

Transferrin variant (Fragment)

Transforming growth factor, beta-induced,

$68 \mathrm{kDa}$ variant (Fragment)

Transketolase

Triosephosphate isomerase

Tripartite motif protein TRIM29 is oform alpha

variant (Fragment)

Tubulin alpha-4A chain

Ubiquitin carboxyl-terminal hydrolase 5

Ubiquitin-activating enzyme E1 (A1S9T and

BN75 temperature sensitivity complementing)

isoform CRA_a

Vimentin

Voltage-dependent anion-selective channel

protein 1

Zinc-alpha-2-glycoprotein
103

80

149

111

32

18

240

180

21

58

102

139

203

121

161

178

347

245

36

240

125

91

12

218

236

144

309

86

310

212

60

173

191

106

58

\begin{tabular}{|l|l|}
\hline 144 & 106 \\
\hline 223 & 202 \\
\hline 297 & 357 \\
\hline
\end{tabular}

\begin{tabular}{|c|c|}
\hline 126 & 68 \\
\hline 14 & 14 \\
\hline 281 & 200 \\
\hline 105 & 125 \\
\hline
\end{tabular}

Arginase-1

Cathepsin D (Lysosomal aspartyl peptidase),

is oform CRA_a

Gasdermin-A

cDNA FU44920 fis, clone BRAMY3011501,

highly similar to Heterogeneous nuclear

ribonucleoprotein $\mathrm{U}$

Proteasome subunit alpha type (Fragment)

Heterochromatin protein 1-binding protein 3

Transaldolase

SFPQ protein (Fragment)

Clathrin heavy chain

Tubulin alpha-4A chain

Mitochondrial heat shock $60 \mathrm{kD}$ protein 1

variant 1

Nascent polypeptide-associated complex

subunit alpha, muscle-specific form

Adenylate kinase 2, mitochondrial

cDNA FU78244, highly similar to Homo

sapiens eukaryotic translation initiation

factor 4A, is oform 1 (EIF4A1), mRNA

SLC25A5 protein (Fragment)

RAB14, member RAS oncogene family,

is oform CRA_a

PMVK protein (Fragment)

$60 S$ ribosomal protein $\mathrm{L} 10 \mathrm{a}$

Pyruvate dehydrogenase E1 component

subunit beta, mitochondrial

Glucose-6-phosphate isomerase (Fragment)

Amyloid $\mathrm{P}$ component, serum

14-3-3 beta/alpha

His tone $\mathrm{H} 1.0$

$40 S$ ribosomal protein S11

cDNA FU78504, highly similar to Homo

sapiens keratin 6A (KRT6A), mRNA

Dopamine receptor interacting protein 4

Chromosome 7 open reading frame 24

Vol tage-dependent anion-selective channel

protein 1

Extracellular superoxide dismutase [Cu-Zn]

Periplakin

Alcohol dehydrogenase IB (Class I), beta

polypeptide, isoform CRA_a

Filamin A

Ubiquitin carboxyl-terminal hydrolase 5

cDNA, FU94198, highly similar to Homo

sapiens carboxypeptidase A3 (mast cell)

(CPA3), mRNA

Superoxide dismutase [Cu-Zn]

Tenascin

Chloride intracellular channel protein

PSME1 protein (Fragment)

Osteoglycin OG

Chaperonin containing TCP1, subunit 2

(Beta), is oform CRA_b

Insulin-degrading enzyme

\begin{tabular}{|c|c|}
\hline 192 & 159 \\
\hline 198 & 153 \\
\hline 200 & 244 \\
\hline 201 & 260 \\
\hline 203 & 180 \\
\hline 205 & 242 \\
\hline 212 & 180 \\
\hline 218 & 218 \\
\hline 220 & 147 \\
\hline 223 & 202 \\
\hline 225 & 245 \\
\hline 226 & 179 \\
\hline 235 & 231 \\
\hline 235 & 238 \\
\hline 236 & 92 \\
\hline 240 & 213 \\
\hline 240 & 235 \\
\hline 242 & 164 \\
\hline 245 & 184 \\
\hline 247 & 205 \\
\hline 255 & 96 \\
\hline 259 & 183 \\
\hline 264 & 215 \\
\hline 268 & 147 \\
\hline 271 & 67 \\
\hline 272 & 155 \\
\hline 278 & 107 \\
\hline 281 & 200 \\
\hline 283 & 195 \\
\hline 287 & 114 \\
\hline 288 & 288 \\
\hline 292 & 154 \\
\hline 297 & 357 \\
\hline 302 & 231 \\
\hline 309 & 234 \\
\hline 310 & 155 \\
\hline 337 & 167 \\
\hline 347 & 256 \\
\hline 355 & 162 \\
\hline 371 & 275 \\
\hline 415 & 275 \\
\hline
\end{tabular}


40 S ribosomal protein $\mathrm{S} 11 \mathrm{OS}=$ Homo sapiens $\mathrm{GN}=\mathrm{RPS} 11 \mathrm{PE}=1 \mathrm{SV}=3$

40 S ribosomal protein $\mathrm{S} 12 \mathrm{OS}=$ Homo sapiens $\mathrm{GN}=\mathrm{RPS} 12 \mathrm{PE}=1 \mathrm{SV}=3$ $40 \mathrm{~S}$ ribosomal protein $\mathrm{S} 14 \mathrm{OS}=$ Homo sapiens $\mathrm{GN}=\mathrm{RPS} 14 \mathrm{PE}=1 \mathrm{SV}=3$ 40 S ribosomal protein $\mathrm{S} 16 \mathrm{OS}=$ Homo sapiens $\mathrm{GN}=\mathrm{RPS} 16 \mathrm{PE}=1 \mathrm{SV}=2$ 40 S ribosomal protein $\mathrm{S} 18 \mathrm{OS}=$ Homo sapiens $\mathrm{GN}=\mathrm{RPS} 18 \mathrm{PE}=1 \mathrm{SV}=3$ $40 S$ ribosomal protein $\mathrm{S} 19 \mathrm{OS}=\mathrm{Homo}$ sapiens $\mathrm{GN}=\mathrm{RPS} 19 \mathrm{PE}=1 \mathrm{SV}=2$ $40 \mathrm{~S}$ ribosomal protein $\mathrm{S} 2 \mathrm{OS}=\mathrm{Homo}$ sapiens $\mathrm{GN}=\mathrm{RPS} 2 \mathrm{PE}=1 \mathrm{SV}=2$ $40 S$ ribosomal protein $S 20$ OS=Homo sapiens $G N=R P S 20 P E=1 S V=1$ $40 \mathrm{~S}$ ribosomal protein $\mathrm{S} 23 \mathrm{OS}=$ Homo sapiens $\mathrm{GN}=\mathrm{RPS} 23 \mathrm{PE}=1 \mathrm{SV}=3$ 40 S ribosomal protein $\mathrm{S} 25 \mathrm{OS}=$ Homo sapiens $\mathrm{GN}=\mathrm{RPS} 25 \mathrm{PE}=1 \mathrm{SV}=1$ 40 S ribosomal protein $\mathrm{S} 28 \mathrm{OS}=$ Homo sapiens $\mathrm{GN}=\mathrm{RPS} 28 \mathrm{PE}=1 \mathrm{SV}=1$ $40 \mathrm{~S}$ ribosomal protein $\mathrm{S} 3 \mathrm{OS}=$ Homo sapiens $\mathrm{GN}=\mathrm{RPS} 3 \mathrm{PE}=1 \mathrm{SV}=2$

40 S ribosomal protein $S 3 a$ OS=Homo sapiens $G N=R P S 3 A$ PE $=1 S V=2$ $40 S$ ribosomal protein $S 4, X$ is oform $O S=$ Homo sapiens $G N=R P S 4 X P E=1 S V=2$ $40 S$ ribosomal protein $\mathrm{S} 5 \mathrm{OS}=$ Homo sapiens $\mathrm{GN}=\mathrm{RPS} 5 \mathrm{PE}=1 \mathrm{SV}=4$ $40 S$ ribosomal protein $\mathrm{S} 6 \mathrm{OS}=\mathrm{Homo}$ sapiens $\mathrm{GN}=\mathrm{RPS} 6 \mathrm{PE}=1 \mathrm{SV}=1$ 40 S ribosomal protein $\mathrm{S7} \mathrm{OS}=\mathrm{Homo}$ sapiens $\mathrm{GN}=\mathrm{RPS7} \mathrm{PE}=1 \mathrm{SV}=1$ $40 \mathrm{~S}$ ribosomal protein $\mathrm{S} 8 \mathrm{OS}=$ Homo sapiens $\mathrm{GN}=\mathrm{RPS} 8 \mathrm{PE}=1 \mathrm{SV}=2$ $40 S$ ribosomal protein $S 9 \mathrm{OS}=$ Homo sapiens $\mathrm{GN}=\mathrm{RPS9} \mathrm{PE}=1 \mathrm{SV}=3$ $40 \mathrm{~S}$ ribosomal protein $\mathrm{SA}$ OS=Homo sapiens $\mathrm{GN}=\mathrm{RPSA} P \mathrm{PE}=1 \mathrm{SV}=4$ $60 \mathrm{kDa}$ heat shock protein, mitochondrial OS=Homo sapiens $\mathrm{GN}=\mathrm{HSPD} 1 \mathrm{PE}=1 \mathrm{SV}=2$ $60 S$ acidic ribosomal protein $P 0$-like $O S=$ Homo sapiens $G N=R P L P 0 P 6 P E=5 S V=1$ $60 \mathrm{~S}$ ribosomal protein $\mathrm{L10a} \mathrm{OS}=\mathrm{H}$ mo sapiens $\mathrm{GN}=\mathrm{RPL10A} P E=1 \mathrm{SV}=2$ $60 S$ ribosomal protein $\mathrm{L} 11 \mathrm{OS}=$ Homo sapiens $\mathrm{GN}=\mathrm{RPL} 11 \mathrm{PE}=1 \mathrm{SV}=2$ $60 S$ ribosomal protein $\mathrm{L} 13$ OS=Homo sapiens $\mathrm{GN}=\mathrm{RPL} 13 \mathrm{PE}=1 \mathrm{SV}=4$ $60 S$ ribosomal protein $L 17$ OS=Homo sapiens $G N=R P L 17 P E=1 S V=3$ $60 S$ ribosomal protein $\mathrm{L} 18 \mathrm{OS}=\mathrm{Homo}$ sapiens $\mathrm{GN}=\mathrm{RPL18} \mathrm{PE}=1 \mathrm{SV}=2$ $60 S$ ribosomal protein $\mathrm{L} 19 \mathrm{OS}=\mathrm{Homo}$ sapiens $\mathrm{GN}=\mathrm{RPL19} P E=1 \mathrm{SV}=1$ $60 S$ ribosomal protein $L 21$ OS=Homo sapiens $G N=R P L 21 P E=1 S V=2$ $60 S$ ribosomal protein $L 22$ OS=Homo sapiens $G N=R P L 22 P E=1 S V=2$ $60 S$ ribosomal protein $L 23$ OS=Homo sapiens $G N=R P L 23 P E=1 S V=1$ $60 \mathrm{~S}$ ribosomal protein $\mathrm{L} 23 \mathrm{a} \mathrm{OS}=\mathrm{Homo}$ sapiens $\mathrm{GN}=\mathrm{RPL23A} P E=1 \mathrm{SV}=1$ $60 S$ ribosomal protein $L 24$ OS=Homo sapiens $G N=R P L 24 P E=1 S V=1$ $60 S$ ribosomal protein $L 26$-like $1 \mathrm{OS}=$ Homo sapiens $\mathrm{GN}=\mathrm{RPL26L1} P E=1 \mathrm{SV}=1$ $60 S$ ribosomal protein $L 27$ OS=Homo sapiens $G N=R P L 27 P E=1 S V=2$ $60 S$ ribosomal protein $L 27 a$ OS=Homo sapiens GN=RPL27A PE $=1 \mathrm{SV}=2$ $60 S$ ribosomal protein $L 29$ OS=Homo sapiens $G N=R P L 29 P E=1 S V=2$ $60 S$ ribosomal protein $L 3$ OS=Homo sapiens $G N=R P L 3 P E=1 S V=2$ $60 S$ ribosomal protein $L 31$ OS=Homo sapiens $G N=R P L 31 P E=1 S V=1$ $60 S$ ribosomal protein $L 34$ OS=Homo sapiens $G N=R P L 34 P E=1 S V=3$ $60 S$ ribosomal protein $\mathrm{L} 36 \mathrm{OS}=\mathrm{Homo}$ sapiens $\mathrm{GN}=\mathrm{RPL} 36 \mathrm{PE}=1 \mathrm{SV}=3$ 60 S ribosomal protein $L 5 O S=$ Homo sapiens $G N=R P L 5 P E=1 S V=3$ 60 S ribosomal protein $L 6$ OS=Homo sapiens $G N=R P L 6 P E=1 S V=3$ $60 S$ ribosomal protein $L 7 \mathrm{OS}=$ Homo sapiens $\mathrm{GN}=\mathrm{RPL7} P E=1 \mathrm{SV}=1$ $60 \mathrm{~S}$ ribosomal protein $\mathrm{L7a} O \mathrm{OS}=\mathrm{Homo}$ sapiens $\mathrm{GN}=\mathrm{RPL7A} P E=1 \mathrm{SV}=2$ $60 S$ ribosomal protein $L 8 O S=$ Homo sapiens $G N=R P L 8 P E=1 S V=2$ 60 S ribosomal protein $L 9 O S=$ Homo sapiens $G N=R P L 9 P E=1 S V=1$ 6-phosphogluconolactonase $\mathrm{OS}=$ Homo sapiens $\mathrm{GN}=\mathrm{PGLS} P \mathrm{PE}=1 \mathrm{SV}=2$ $78 \mathrm{kDa}$ glucose-regulated protein OS=Homo sapiens $\mathrm{GN}=\mathrm{HSPA} 5 \mathrm{PE}=1 \mathrm{SV}=2$ Aconitate hydratase, mitochondrial $\mathrm{OS}=$ Homo sapiens $\mathrm{GN}=\mathrm{ACO} 2 \mathrm{PE}=1 \mathrm{SV}=2$ Actin, cytoplasmic $1 \mathrm{OS}=$ Homo sapiens $\mathrm{GN}=\mathrm{ACTB} P \mathrm{PE}=1 \mathrm{SV}=1$ Actin-related protein $2 \mathrm{OS}=$ Homo sapiens $\mathrm{GN}=\mathrm{ACTR} 2 \mathrm{PE}=1 \mathrm{SV}=1$ Actin-related protein $2 / 3$ complex subunit $1 \mathrm{~A} O \mathrm{OS}=$ Homo sapiens $\mathrm{GN}=\mathrm{ARPC} 1 \mathrm{~A} P E=1 \mathrm{SV}=2$ Actin-related protein $2 / 3$ complex subunit $3 \mathrm{OS}=$ Homo sapiens $\mathrm{GN}=\mathrm{ARPC} 3 \mathrm{PE}=1 \mathrm{SV}=3$ Actin-related protein $2 / 3$ complex subunit $4 \mathrm{OS}=$ Homo sapiens $\mathrm{GN}=\mathrm{ARPC} 4 \mathrm{PE}=1 \mathrm{SV}=3$ Adenine phosphoribosyltransferase OS=Homo sapiens GN=APRT PE=1 SV=2 Adenylate kinase 2, mitochondrial $\mathrm{OS}=$ Homo sapiens $\mathrm{GN}=\mathrm{AK} 2 \mathrm{PE}=1 \mathrm{SV}=2$

Accession Number

CH10_HUMAN

1433B_HUMAN

1433E_HUMAN

1433S_HUMAN

1433Z_HUMAN

PSMD2_HUMAN

RS11_HUMAN

RS12_HUMAN

RS14_HUMAN

RS16_HUMAN

RS18_HUMAN

RS19_HUMAN

RS2_HUMAN

RS20_HUMAN

RS23_HUMAN

RS25_HUMAN

RS28_HUMAN

RS3_HUMAN

RS3A_HUMAN

RS4X_HUMAN

RS5_HUMAN

RS6_HUMAN

RS7_HUMAN

RS8_HUMAN

RS9_HUMAN

RSSA_HUMAN

CH60_HUMAN

RLAOL_HUMAN

RL10A_HUMAN

RL11_HUMAN

RL13_HUMAN

RL17_HUMAN

RL18_HUMAN

RL19_HUMAN

RL21_HUMAN

RL22_HUMAN

RL23_HUMAN

RL23A_HUMAN

RL24_HUMAN

RL26L_HUMAN

RL27_HUMAN

RL27A_HUMAN

RL29_HUMAN

RL3_HUMAN

RL31_HUMAN

RL34_HUMAN

RL36_HUMAN

RL5_HUMAN

RL6_HUMAN

RL7_HUMAN

RL7A_HUMAN

RL8_HUMAN

RL9_HUMAN

6PGL_HUMAN

GRP78 HUMAN

ACON_HUMAN

ACTB_HUMAN

ARP2_HUMAN

ARC1A_HUMAN

ARPC3_HUMAN

ARPC4_HUMAN APT HUMAN

KAD2_HUMAN 
Cytoplasmic dynein 1 heavy chain $1 \mathrm{OS}=$ Homo sapiens GN=DYNC1H1 PE=1 SV=5 $D$-3-phosphoglycerate dehydrogenase $\mathrm{OS}=$ Homo sapiens $\mathrm{GN}=\mathrm{PHGDH} P E=1 \mathrm{SV}=4$ Decorin OS=Homo sapiens GN=DCN PE=1 SV=1 Desmin OS=Homo sapiens $G N=D E S P E=1 S V=3$

Desmocollin-1 OS=Homo sapiens GN=DSC1 PE=1 SV=2

Desmocollin-3 OS=Homo sapiens GN=DSC3 PE=1 SV=3

Desmoglein $-1 \mathrm{OS}=$ Homo sapiens $\mathrm{GN}=\mathrm{DSG1} P \mathrm{PE}=1 \mathrm{SV}=2$

Desmoplakin OS=Homo sapiens GN=DSP PE=1 SV=3

DNA-(apurinic or apyrimidinic site) lyase OS=Homo sapiens $G N=A P E X 1 P E=1 S V=2$

ELAV-like protein $1 \mathrm{OS}=$ Homo sapiens $\mathrm{GN}=\mathrm{ELAVL1} P E=1 \mathrm{SV}=2$

Elongation factor 1-alpha $1 \mathrm{OS}=$ Homo sapiens $\mathrm{GN}=\mathrm{EEF} 1 \mathrm{~A} 1 \mathrm{PE}=1 \mathrm{SV}=1$

Elongation factor 1-delta OS=Homo sapiens $\mathrm{GN}=\mathrm{EEF} 1 \mathrm{D} P E=1 \mathrm{SV}=5$

Elongation factor 1-gamma OS=Homo sapiens $\mathrm{GN}=\mathrm{EEF} 1 \mathrm{G} P E=1 \mathrm{SV}=3$

Elongation factor $2 \mathrm{OS}=$ Homo sapiens $\mathrm{GN}=\mathrm{EEF} 2 \mathrm{PE}=1 \mathrm{SV}=4$

Endoplasmin OS=Homo sapiens GN=HSP90B1 PE=1 SV=1

Envoplakin OS=Homo sapiens GN=EVPL $P E=1 S V=3$

Epiplakin OS=Homo sapiens GN=EPPK1 PE=1 SV=2

Erythrocyte band 7 integral membrane protein $O S=H o m o$ sapiens $G N=S T O M P E=1 S V=3$

Eukaryotic initiation factor $4 A-I$ OS=Homo sapiens $G N=E I F 4 A 1 P E=1 S V=1$

Eukaryotic translation initiation factor 3 subunit $B$ OS=Homo sapiens $G N=E I F 3 B P E=1 S V=3$

Eukaryotic translation initiation factor 3 subunit $L O S=$ Homo sapiens $G N=E I F 3 L P E=1 S V=1$

Eukaryotic translation initiation factor $4 \mathrm{~B}$ OS=Homo sapiens $\mathrm{GN}=\mathrm{EIF} 4 \mathrm{~B} P \mathrm{PE}=1 \mathrm{SV}=2$

Eukaryotic translation initiation factor $5 \mathrm{~A}-1 \mathrm{OS}=$ Homo sapiens $\mathrm{GN}=\mathrm{EIF5A} P \mathrm{PE}=1 \mathrm{SV}=2$

Extracellular superoxide dismutase [Cu-Zn] OS=Homo sapiens $\mathrm{GN}=\mathrm{SOD} 3 \mathrm{PE}=1 \mathrm{SV}=2$

Ezrin OS=Homo sapiens GN=EZR PE=1 SV=4

F-actin-capping protein subunit alpha- $1 \mathrm{OS}=$ Homo sapiens $\mathrm{GN}=\mathrm{CAPZA1} \mathrm{PE}=1 \mathrm{SV}=3$

Far upstream element-binding protein $2 \mathrm{OS}=$ Homo sapiens $\mathrm{GN}=\mathrm{KHSRP} P E=1 \mathrm{SV}=4$

Fibrinogen alpha chain $\mathrm{OS}=$ Homo sapiens $\mathrm{GN}=\mathrm{FGA} P E=1 \mathrm{SV}=2$

Filaggrin OS=Homo sapiens $G N=F L G ~ P E=1 S V=3$

Filaggrin-2 OS=Homo sapiens $\mathrm{GN}=\mathrm{FLG} 2 \mathrm{PE}=1 \mathrm{SV}=1$

Filamin- $A$ OS=Homo sapiens $\mathrm{GN}=\mathrm{FLNA} P E=1 \mathrm{SV}=4$

Filamin-B OS=Homo sapiens $\mathrm{GN}=\mathrm{FLNB} P E=1 \mathrm{SV}=2$

Fructose-bisphosphate aldolase $A$ OS=Homo sapiens $G N=A L D O A ~ P E=1 S V=2$

Fructose-bisphosphate aldolase $C$ OS=Homo sapiens $G N=A L D O C P E=1 S V=2$

Galectin-1 OS=Homo sapiens GN=LGALS1 PE=1 SV=2

Galectin- 3 OS=Homo sapiens $G N=L G A L S 3 P E=1 S V=5$

Galectin-7 OS=Homo sapiens GN=LGALS7 PE=1 SV=2

Gamma-glutamylcyclotransferase OS=Homo sapiens $\mathrm{GN}=\mathrm{GGCT} P E=1 \mathrm{SV}=1$

Gasdermin-A OS=Homo sapiens $G N=G S D M A ~ P E=2 ~ S V=4$

GDP-L-fucose synthase OS=Homo sapiens $G N=T S T A 3 P E=1 S V=1$

Gelsolin OS=Homo sapiens $\mathrm{GN}=\mathrm{GSN} P \mathrm{PE}=1 \mathrm{SV}=1$

Glucose-6-phosphate isomerase OS=Homo sapiens GN=GPI PE=1 SV=4

Glutathione S-transferase omega-1 OS=Homo sapiens GN=GSTO1 PE=1 SV=2

Glyceraldehyde-3-phosphate dehydrogenase OS=Homo sapiens $G N=G A P D H P E=1 S V=3$

Glyoxalase domain-containing protein $4 \mathrm{OS}=$ Homo sapiens $\mathrm{GN}=\mathrm{GLOD} 4 \mathrm{PE}=1 \mathrm{SV}=1$

GTP-binding nuclear protein Ran OS=Homo sapiens $G N=R A N ~ P E=1 S V=3$

Guanine nucleotide-binding protein $G(i)$ subunit alpha- $1 \mathrm{OS}=$ Homo sapiens $\mathrm{GN}=\mathrm{GNAI} 1 \mathrm{PE}=1 \mathrm{SV}=2$

Guanine nucleotide-binding protein $G(i)$ subunit alpha- 2 OS=Homo sapiens $G N=G N A \mid 2 P E=1 S V=3$

Guanine nucleotide-binding protein subunit al pha-13 OS=Homo sapiens GN=GNA13 PE=1 SV=2

Guanine nucleotide-binding protein subunit beta-2-like $1 \mathrm{OS}=$ Homo sapiens $\mathrm{GN}=\mathrm{GNB} 2 \mathrm{~L} 1 \mathrm{PE}=1 \mathrm{SV}=3$

Haptoglobin-related protein OS=Homo sapiens GN=HPR PE=2 SV=2

Heat shock $70 \mathrm{kDa}$ protein $1 \mathrm{~A} / 1 \mathrm{~B}$ OS=Homo sapiens $\mathrm{GN}=\mathrm{HSPA} 1 \mathrm{~A} P E=1 \mathrm{SV}=5$

Heat shock cognate $71 \mathrm{kDa}$ protein $\mathrm{OS}=$ Homo sapiens $\mathrm{GN}=\mathrm{HSPA} 8 \mathrm{PE}=1 \mathrm{SV}=1$

Heat shock protein beta-1 OS=Homo sapiens GN=HSPB1 PE=1 SV=2

Heat shock protein HSP 90-alpha OS=Homo sapiens GN=HSP90AA1 $P E=1 \mathrm{SV}=5$

Heat shock protein HSP 90-beta OS=Homo sapiens GN=HSP90AB1 $P E=1 \mathrm{SV}=4$

Hemoglobin subunit al pha OS=Homo sapiens $G N=H B A 1 P E=1 S V=2$

Hemoglobin subunit beta OS=Homo sapiens $\mathrm{GN}=\mathrm{HBB} P E=1 \mathrm{SV}=2$

Hemopexin OS=Homo sapiens GN=HPX PE=1 SV=2

Hepatoma-derived growth factor OS=Homo sapiens GN=HDGF $P E=1 \mathrm{SV}=1$

Heterochromatin protein 1-binding protein $3 \mathrm{OS}=$ Homo sapiens $\mathrm{GN}=\mathrm{HP} 1 \mathrm{BP} 3 \mathrm{PE}=1 \mathrm{SV}=1$

Heterogeneous nuclear ribonucleoprotein $\mathrm{A} 1 \mathrm{OS}=$ Homo sapiens $\mathrm{GN}=\mathrm{HNRNPA1} \mathrm{PE}=1 \mathrm{SV}=5$

Heterogeneous nuclear ribonucleoprotein $\mathrm{A} 3 \mathrm{OS}=$ Homo sapiens $\mathrm{GN}=\mathrm{HNRNPA3} P E=1 \mathrm{SV}=2$

Heterogeneous nuclear ribonucleoprotein $\mathrm{K} O S=$ Homo sapiens $G N=H N R N P K P E=1 \mathrm{SV}=1$

Heterogeneous nuclear ribonucleoprotein Q OS=Homo sapiens GN=SYNCRIP PE=1 SV=2

DYHC1 HUMAN

SERA HUMAN

PGS2_HUMAN

DESM HUMAN

DSC1 HUMAN

DSC3 HUMAN

DSG1 HUMAN

DESP_HUMAN

APEX1_HUMAN

ELAV1_HUMAN

EF1A1_HUMAN

EF1D_HUMAN

EF1G_HUMAN

EF2_HUMAN

ENPL_HUMAN

EVPL_HUMAN

EPIPL_HUMAN

STOM HUMAN

IF4A1_HUMAN

EIF3B_HUMAN

EIF3L HUMAN

IF4B HUMAN

IF5A1_HUMAN

SODE HUMAN

EZRI HUMAN

CAZA1_HUMAN

FUBP2_HUMAN

FIBA_HUMAN

FILA_HUMAN

FILA2_HUMAN

FLNA_HUMAN

FLNB HUMAN

ALDOA_HUMAN

ALDOC HUMAN

LEG1_HUMAN

LEG3_HUMAN

LEG7_HUMAN

GGCT HUMAN

GSDMA HUMAN

FCL HUMAN

GELS_HUMAN

G6PI_HUMAN

GSTO1_HUMAN

G3P_HUMAN

GLOD4_HUMAN

RAN_HUMAN

GNAI1_HUMAN

GNAI2_HUMAN

GNA13 HUMAN

GBLP HUMAN

HPTR HUMAN

HSP71 HUMAN

HSP7C HUMAN

HSPB1 HUMAN

HS9OA_HUMAN

HS90B HUMAN

HBA_HUMAN

HBB_HUMAN

HEMO_HUMAN

HDGF HUMAN

HP1B3 HUMAN

ROA1_HUMAN

ROA3 HUMAN

HNRPK_HUMAN

HNRPQ_HUMAN
0.74

0.56

0.42

0.11

0.96

0.78

0.36

0.72

0.79

0.35

0.34

0.5

0.9

$<0.001$

0.85

1.3

1.1

0.7

1.3

8

$<0.001$

1.2

0.29

0.42

0.74

0.11

0.45

0.41

0.12

0.8

0.41

0.56

0.4

0.8

0.8

0.64

0.74

1.1

0.63

0.7

0.4

0.53

0.43

0.03

0.9

0.32

0.99

0.016

0.075

2.1

0.9

0.85

0.4

0.8

0.24

0.74

0.4

0.9

0.17

0.86

0.3

0.12

0.7

0.52

0.3

1.4

0.3

0.2

0.96

0.6

0.5

1

0.3

$<0.001$

4.1

$<0.001$

0.4

1.4

0.47

0.19

0.98

0.045

0.29

0.21

0.09

0.22

0.75

0.91

1.5

0.31

0.5

0.041

0.39

1.4

1.2

0.4

0.4

1.7

12

0.8

0.7

0.9

0.61

0.016

0.05

0.2

0.24

0.36

0.39

0.92

1.3 
Heterogeneous nuclear ribonucleoprotein U OS=Homo sapiens GN=HNRNPU PE=1 SV=6 Heterogeneous nuclear ribonucleoproteins A2/B1 OS=Homo sapiens $G N=H N R N P A 2 B 1 P E=1 S V=2$ Heterogeneous nuclear ribonucleoproteins $\mathrm{C} 1 / \mathrm{C} 2 \mathrm{OS}=\mathrm{H}$ omo sapiens $\mathrm{GN}=\mathrm{HNRNPC} P E=1 \mathrm{SV}=4$ Hexokinase-1 OS=Homo sapiens GN=HK1 PE=1 SV=3

High mobility group protein $\mathrm{B} 1 \mathrm{OS}=$ Homo sapiens $\mathrm{GN}=\mathrm{HMGB} 1 \mathrm{PE}=1 \mathrm{SV}=3$

Histone $\mathrm{H} 1.0 \mathrm{OS}=$ Homo sapiens $\mathrm{GN}=\mathrm{H} 1 \mathrm{FO} \mathrm{PE}=1 \mathrm{SV}=3$

Histone H1.2 OS=Homo sapiens GN=HIST1H1C PE=1 SV=2

Histone $\mathrm{H} 1.5 \mathrm{OS}=\mathrm{Homo}$ sapiens $\mathrm{GN}=\mathrm{HIST} 1 \mathrm{H} 1 \mathrm{~B} P \mathrm{PE}=1 \mathrm{SV}=3$

Histone $\mathrm{H} 2 \mathrm{~A}$ type $1-\mathrm{B} / \mathrm{E}$ OS=Homo sapiens $\mathrm{GN}=\mathrm{HIST} 1 \mathrm{H} 2 \mathrm{AB} \mathrm{PE}=1 \mathrm{SV}=2$

Histone H2A.V OS=Homo sapiens GN=H2AFV PE=1 SV=3

Histone $\mathrm{H} 2 \mathrm{~B}$ type 1-B OS=Homo sapiens $\mathrm{GN}=\mathrm{HIST} 1 \mathrm{H} 2 \mathrm{BB} P E=1 \mathrm{SV}=2$

Histone $\mathrm{H} 2 \mathrm{~B}$ type $1-\mathrm{C} / \mathrm{E} / \mathrm{F} / \mathrm{G} / \mathrm{I} \mathrm{OS}=$ Homo sapiens $\mathrm{GN}=\mathrm{HIST} 1 \mathrm{H} 2 \mathrm{BC} P \mathrm{PE}=1 \mathrm{SV}=4$

Histone H3.1t OS=Homo sapiens GN=HIST3H3 PE=1 SV=3

Histone H4 OS=Homo sapiens GN=HIST1H4A PE=1 SV=2

HLA class I histocompatibility antigen, $A-2$ al pha chain OS=Homo sapiens $G N=H L A-A \quad P E=1 S V=1$

HLA class I histocompatibility antigen, B-7 alpha chain OS=Homo sapiens $G N=H L A-B \quad P E=1 \mathrm{SV}=3$

Ig alpha-1 chain $C$ region OS=Homo sapiens $G N=I G H A 1 P E=1 S V=2$

Ig gamma- 1 chain $\mathrm{C}$ region OS=Homo sapiens $\mathrm{GN}=I \mathrm{GHG} 1 \mathrm{PE}=1 \mathrm{SV}=1$

Ig mu chain $\mathrm{C}$ region $\mathrm{OS}=$ Homo sapiens $\mathrm{GN}=I \mathrm{GHM} P E=1 \mathrm{SV}=3$

Importin subunit beta-1 OS=Homo sapiens GN=KPNB1 PE=1 SV=2

Inorganic pyrophosphatase OS=Homo sapiens GN=PPA1 PE=1 SV=2

Inositol monophosphatase $2 \mathrm{OS}=$ Homo sapiens $\mathrm{GN}=\mathrm{IMPA} 2 \mathrm{PE}=1 \mathrm{SV}=1$

Insulin-degrading enzyme OS=Homo sapiens $G N=I D E P E=1 S V=4$

Integrin beta- $4 \mathrm{OS}=$ Homo sapiens $\mathrm{GN}=\mathrm{ITGB} 4 \mathrm{PE}=1 \mathrm{SV}=5$

Interleukin enhancer-binding factor $3 \mathrm{OS}=$ Homo sapiens $\mathrm{GN}=\mathrm{ILF} 3 \mathrm{PE}=1 \mathrm{SV}=3$

Interleukin-18 OS=Homo sapiens GN=IL18 PE=1 SV=1

Involucrin OS=Homo sapiens GN=IVL PE=1 SV=2

Junction plakoglobin OS=Homo sapiens GN=JUP PE=1 SV=3

Keratin, type I cuticular Ha1 OS=Homo sapiens GN=KRT31 PE=1 SV=3

Keratin, type I cytoskeletal 10 OS=Homo sapiens $G N=K R T 10 P E=1 S V=6$ Keratin, type I cytoskeletal $14 \mathrm{OS}=$ Homo sapiens $\mathrm{GN}=\mathrm{KRT} 14 \mathrm{PE}=1 \mathrm{SV}=4$ Keratin, type I cytoskeletal $15 \mathrm{OS}=$ Homo sapiens $\mathrm{GN}=\mathrm{KRT} 15 \mathrm{PE}=1 \mathrm{SV}=3$ Keratin, type I cytoskeletal $9 \mathrm{OS}=$ Homo sapiens $\mathrm{GN}=\mathrm{KRT} 9 \mathrm{PE}=1 \mathrm{SV}=3$ Keratin, type II cuticular Hb1 OS=Homo sapiens GN=KRT81 PE=1 SV=3 Keratin, type II cytoskeletal $1 \mathrm{OS}=$ Homo sapiens $\mathrm{GN}=\mathrm{KRT} 1 \mathrm{PE}=1 \mathrm{SV}=6$

Keratin, type II cytoskeletal $1 \mathrm{~b}$ OS=Homo sapiens $\mathrm{GN}=\mathrm{KRT77} P \mathrm{PE}=1 \mathrm{SV}=3$

Keratin, type II cytoskeletal 2 epidermal OS=Homo sapiens GN=KRT2 PE=1 SV=2

Keratin, type II cytoskeletal $5 \mathrm{OS}=$ Homo sapiens $\mathrm{GN}=\mathrm{KRT5} P \mathrm{PE}=1 \mathrm{SV}=3$

Keratin, type II cytoskeletal $6 \mathrm{~A}$ OS=Homo sapiens $\mathrm{GN}=\mathrm{KRT6A} P E=1 \mathrm{SV}=3$

Keratin, type II cytoskeletal 78 OS=Homo sapiens $\mathrm{GN}=\mathrm{KRT78} P \mathrm{PE}=1 \mathrm{SV}=2$

Lactoylglutathione lyase OS=Homo sapiens $\mathrm{GN}=\mathrm{GLO} 1 \mathrm{PE}=1 \mathrm{SV}=4$

LanC-like protein $1 \mathrm{OS}=$ Homo sapiens GN=LANCL1 PE=1 SV=1

L-lactate dehydrogenase $A$ chain $O S=H o m o$ sapiens $G N=L D H A ~ P E=1 S V=2$

L-lactate dehydrogenase $B$ chain $O S=H o m o$ sapiens $G N=L D H B P E=1 S V=2$

Lumican OS=Homo sapiens GN=LUM PE=1 SV=2

Macrophage-capping protein OS=Homo sapiens GN=CAPG PE=1 SV=2

Malate dehydrogenase, mitochondrial $\mathrm{OS}=$ Homo sapiens $\mathrm{GN}=\mathrm{MDH} 2 \mathrm{PE}=1 \mathrm{SV}=3$

Mast cell carboxypeptidase $A$ OS=Homo sapiens $\mathrm{GN}=\mathrm{CPA} 3 \mathrm{PE}=1 \mathrm{SV}=2$

Membrane-associated progesterone receptor component 2 OS=Homo sapiens GN=PGRMC2 PE=1 SV=1 Mimecan OS=Homo sapiens $\mathrm{GN}=\mathrm{OGN} P \mathrm{PE}=1 \mathrm{SV}=1$

Moesin OS=Homo sapiens GN=MSN PE=1 SV=3

Myosin light polypeptide $6 \mathrm{OS}=$ Homo sapiens $\mathrm{GN}=\mathrm{MYL6} \mathrm{PE}=1 \mathrm{SV}=2$

Myosin regulatory light chain $12 \mathrm{~A}$ OS=Homo sapiens $\mathrm{GN}=\mathrm{MYL12A} P \mathrm{PE}=1 \mathrm{SV}=2$

Myosin-11 OS=Homo sapiens GN=MYH11 PE=1 SV=3

Myosin- 9 OS=Homo sapiens GN=MYH9 PE=1 SV=4

Myosin-Ic OS=Homo sapiens GN=MYO1C $P E=1 \mathrm{SV}=4$

NADH-cytochrome b5 reductase $1 \mathrm{OS}=$ Homo sapiens $\mathrm{GN}=\mathrm{CYB} 5 \mathrm{R} 1 \mathrm{PE}=1 \mathrm{SV}=1$

NADH-cytochrome b5 reductase 3 OS=Homo sapiens GN=CYB5R3 PE=1 SV=3

Nascent polypeptide-associated complex subunit alpha, muscle-specific form OS=Homo sapiens

GN=NACA PE=1 SV=1

Neuroblast differentiation-associated protein AHNAK OS=Homo sapiens GN=AHNAK PE=1 SV=2 Nucleolin OS=Homo sapiens GN=NCL PE=1 SV=3

Nucleophosmin OS=Homo sapiens GN=NPM1 PE=1 SV=2

Nucleoside diphosphate kinase B OS=Homo sapiens GN=NME2 PE=1 SV=1

Parathymosin OS=Homo sapiens GN=PTMS PE=1 SV=2

PDZ and LIM domain protein 1 OS=Homo sapiens GN=PDLIM1 PE=1 SV=4

HNRPU HUMAN

ROA2_HUMAN

HNRPC HUMAN

HXK1 HUMAN

HMGB1 HUMAN

H10 HUMAN

H12_HUMAN (+2)

H15_HUMAN

H2A1B_HUMAN

H2AV HUMAN

H2B1B HUMAN

H2B1C_HUMAN

H31T HUMAN

H4_HUMAN

$1 \mathrm{A02}$ HUMAN

1B07_HUMAN

IGHA1_HUMAN

IGHG1_HUMAN

IGHM_HUMAN

IMB1_HUMAN

IPYR HUMAN

IMPA2 HUMAN

IDE HUMAN

ITB4_HUMAN

ILF3_HUMAN

IL18 HUMAN

INVO_HUMAN

PLAK_HUMAN

K1H1 HUMAN

K1C10 HUMAN

K1C14 HUMAN

K1C15 HUMAN

K1C9 HUMAN

KRT81 HUMAN

K2C1_HUMAN

K2C1B_HUMAN

K22E HUMAN

K2C5 HUMAN

K2C6A_HUMAN

K2C78_HUMAN

LGUL_HUMAN

LANC1_HUMAN

LDHA HUMAN

LDHB_HUMAN

LUM_HUMAN

CAPG HUMAN

MDHM_HUMAN

CBPA3_HUMAN

PGRC2 HUMAN

MIME_HUMAN

MOES_HUMAN

MYL6 HUMAN

ML12A HUMAN

MYH11_HUMAN

MYH9 HUMAN

MYO1C HUMAN

NB5R1 HUMAN

NB5R3_HUMAN

NACAM_HUMAN

AHNK_HUMAN

NUCL_HUMAN

NPM HUMAN

NDKB HUMAN

PTMS HUMAN

PDLI1_HUMAN
0.43

0.49

0.4

0.8

0.056

0.74

0.0072

0.8

0.67

0.46

0.39

0.46

0.28

0.33

0.53

0.47

0.84

0.3

0.63

0.17

0.11

0.022

0.8

0.76

0.7

0.61

0.41

0.38

0.29

0.33

0.18

0.11

0.57

0.29

0.57

0.59

0.35

0.55

0.01

0.42

0.55

0.31

0.3

0.22

0.17

0.88

0.11

2.4

0.09

0.98

0.59

0.29

0.3

0.41

0.34

0.34

0.0096

0.62

0.09

0.4

0.36

0.63

0.14

0.94 
Peptidyl-prolyl cis-trans isomerase A OS=Homo sapiens GN=PPIA PE=1 SV=2 Peptidyl-prolyl cis-trans isomerase $B$ OS=Homo sapiens GN=PPIB PE=1 SV $=2$ Peptidyl-prolyl cis-trans isomerase FKBP1A OS=Homo sapiens GN=FKBP1A PE=1 SV=2 Periostin OS=Homo sapiens $G N=P O S T N ~ P E=1 S V=2$ Periplakin OS=Homo sapiens $G N=P P L P E=1 S V=4$ Peroxiredoxin-1 OS=Homo sapiens GN=PRDX1 PE=1 SV=1 Peroxiredoxin-2 OS=Homo sapiens GN=PRDX2 PE $=1 \mathrm{SV}=5$ Peroxiredoxin-5, mitochondrial OS=Homo sapiens GN=PRDX5 PE=1 SV=4 Peroxiredoxin -6 OS=Homo sapiens GN=PRDX6 PE=1 SV=3 Phosphatidylethanolamine-binding protein $1 \mathrm{OS}=$ Homo sapiens $\mathrm{GN}=\mathrm{PEBP} 1 \mathrm{PE}=1 \mathrm{SV}=3$ Phosphoglucomutase-1 OS=Homo sapiens GN=PGM1 PE=1 SV=3

Phosphoglycerate kinase $1 \mathrm{OS}=$ Homo sapiens $\mathrm{GN}=\mathrm{PGK} 1 \mathrm{PE}=1 \mathrm{SV}=3$

Phosphoglycerate mutase $1 \mathrm{OS}=\mathrm{Homo}$ sapiens $\mathrm{GN}=\mathrm{PGAM} 1 \mathrm{PE}=1 \mathrm{SV}=2$

Plakophilin-1 OS=Homo sapiens GN=PKP1 PE=1 SV=2

Plakophilin-3 OS=Homo sapiens GN=PKP3 PE=1 SV=1

Plasminogen activator inhibitor $1 \mathrm{RNA}$-binding protein $\mathrm{OS}=$ Homo sapiens $\mathrm{GN}=\mathrm{SERBP} 1 \mathrm{PE}=1 \mathrm{SV}=2$ Plastin-1 OS=Homo sapiens GN=PLS1 PE=1 SV =2

Plastin-2 OS=Homo sapiens $G N=L C P 1 P E=1 S V=6$ Plectin OS=Homo sapiens GN=PLEC PE=1 SV=3

Poly $(r C)$-binding protein $1 \mathrm{OS}=$ Homo sapiens $\mathrm{GN}=\mathrm{PCBP} 1 \mathrm{PE}=1 \mathrm{SV}=2$

Polypyrimidine tract-binding protein $1 \mathrm{OS}=$ Homo sapiens $\mathrm{GN}=\mathrm{PTBP} 1 \mathrm{PE}=1 \mathrm{SV}=1$ Polyubiquitin-B OS=Homo sapiens $G N=U B B P E=1 S V=1$

Prelamin-A/C OS=Homo sapiens GN=LMNA PE $=1 \mathrm{SV}=1$

Profilin-1 OS=Homo sapiens GN=PFN1 PE=1 SV=2

Programmed cell death 6-interacting protein OS=Homo sapiens GN=PDCD6IP PE=1 SV=1

Prohibitin OS=Homo sapiens GN=PHB PE $=1 \mathrm{SV}=1$

Prohibitin -2 OS=Homo sapiens GN=PHB2 PE $=1 \mathrm{SV}=2$

Prolargin OS=Homo sapiens GN=PRELP PE=1 SV=1

Proteasome subunit alpha type-1 OS=Homo sapiens GN=PSMA1 PE=1 SV=1

Proteasome subunit alpha type- $4 \mathrm{OS}=$ Homo sapiens $\mathrm{GN}=\mathrm{PSMA} 4 \mathrm{PE}=1 \mathrm{SV}=1$

Proteasome subunit alpha type $-5 \mathrm{OS}=$ Homo sapiens $\mathrm{GN}=\mathrm{PSMA5} \mathrm{PE}=1 \mathrm{SV}=3$

Proteasome subunit alpha type- 6 OS=Homo sapiens GN=PSMA6 PE=1 SV $=1$

Proteasome subunit alpha type-7-like OS=Homo sapiens GN=PSMA8 PE=1 SV=3

Proteasome subunit beta type $-5 \mathrm{OS}=\mathrm{Homo}$ sapiens $\mathrm{GN}=\mathrm{PSMB} 5 \mathrm{PE}=1 \mathrm{SV}=3$

Proteasome subunit beta type- 6 OS=Homo sapiens GN=PSMB6 PE=1 SV=4

Protein AHNAK2 OS=Homo sapiens $\mathrm{GN}=\mathrm{AHNAK} 2 \mathrm{PE}=1 \mathrm{SV}=2$

Protein disulfide-isomerase $A 3 \mathrm{OS}=$ Homo sapiens $\mathrm{GN}=\mathrm{PDIA} 3 \mathrm{PE}=1 \mathrm{SV}=4$

Protein disulfide-isomerase $O S=$ Homo sapiens $G N=P 4 H B P E=1 S V=3$

Protein DJ-1 OS=Homo sapiens GN=PARK7 PE $=1 \mathrm{SV}=2$

Protein POF1B OS=Homo sapiens GN=POF1B PE $=1 \mathrm{SV}=2$

Protein $\mathrm{S} 100-\mathrm{A} 16 \mathrm{OS}=$ Homo sapiens $\mathrm{GN}=\mathrm{S} 100 \mathrm{~A} 16 \mathrm{PE}=1 \mathrm{SV}=1$

Protein S100-A4 OS=Homo sapiens GN=S100A4 PE=1 SV=1

Protein transport protein Sec61 subunit beta OS=Homo sapiens GN=SEC61B PE=1 SV=2

Protein-glutamine gamma-glutamyltransferase $E$ OS=Homo sapiens $G N=T G M 3 P E=1 S V=4$

Puromycin-sensitive aminopeptidase OS=Homo sapiens GN=NPEPPS PE $=1 \mathrm{SV}=2$

Putative 40 S ribosomal protein S10-like OS=Homo sapiens GN=RPS10P5 PE=5 SV $=1$

Putative 40S ribosomal protein S26-like 1 OS=Homo sapiens GN=RPS26P11 PE=5 SV=1

Putative 60 s ribosomal protein L13a protein RPL13AP3 OS=Homo sapiens GN=RPL13AP3 PE=5 SV=1

Pyruvate dehydrogenase E1 component subunit beta, mitochondrial OS=Homo sapiens GN=PDHB PE=1

$S V=3$

Pyruvate kinase isozymes M1/M2 OS=Homo sapiens GN=PKM2 PE=1 SV=4

Quinone oxidoreductase $\mathrm{OS}=$ Homo sapiens $\mathrm{GN}=\mathrm{CRYZ} P E=1 \mathrm{SV}=1$

Rab GDP dissociation inhibitor alpha OS=Homo sapiens $\mathrm{GN}=\mathrm{GDI} 1 \mathrm{PE}=1 \mathrm{SV}=2$

Ras GTPase-activating-like protein IQGAP1 OS=Homo sapiens GN=IQGAP1 PE=1 SV=1

Ras-related C3 botulinum toxin substrate $1 \mathrm{OS}=$ Homo sapiens $\mathrm{GN}=\mathrm{RAC1} P \mathrm{PE}=1 \mathrm{SV}=1$

Ras-related protein Rab-10 OS=Homo sapiens GN=RAB10 PE=1 SV=1

Ras-related protein Rab-11A OS=Homo sapiens GN=RAB11A PE $=1 \mathrm{SV}=3$

Ras-related protein Rab-14 OS=Homo sapiens GN=RAB14 PE=1 SV=4

Ras-related protein Rab-1A OS=Homo sapiens GN=RAB1A PE=1 SV=3

Ras-related protein Rab-1B OS=Homo sapiens $G N=R A B 1 B P E=1 S V=1$

Ras-related protein Rab-25 OS=Homo sapiens GN=RAB25 PE=1 SV $=2$

Ras-related protein Rab-5C OS=Homo sapiens $\mathrm{GN}=\mathrm{RAB} 5 \mathrm{C} P \mathrm{E}=1 \mathrm{SV}=2$

Ras-related protein Rab-6A OS=Homo sapiens $\mathrm{GN}=\mathrm{RAB6A} P E=1 \mathrm{SV}=3$

Ras-related protein Rab-7a OS=Homo sapiens GN=RAB7A PE=1 SV $=1$

PPIA HUMAN PPIB HUMAN

FKB1A_HUMAN

POSTN_HUMAN

PEPL_HUMAN

PRDX1_HUMAN

PRDX2_HUMAN

PRDX5_HUMAN

PRDX6_HUMAN

PEBP1 HUMAN

PGM1_HUMAN

PGK1_HUMAN

PGAM1 HUMAN

PKP1_HUMAN

PKP3_HUMAN

PAIRB_HUMAN

PLSI_HUMAN

PLSL_HUMAN

PLEC_HUMAN

PCBP1_HUMAN

PTBP1_HUMAN

UBB_HUMAN

LMNA HUMAN

PROF1_HUMAN

PDC6I HUMAN

PHB HUMAN

PHB2_HUMAN

PRELP_HUMAN

PSA1_HUMAN

PSA4_HUMAN

PSA5_HUMAN

PSA6_HUMAN

PSA7L HUMAN

PSB5 HUMAN

PSB6 HUMAN

AHNK2 HUMAN

PDIA3 HUMAN

PDIA1_HUMAN

PARK7_HUMAN

POF1B_HUMAN

S10AG_HUMAN

S10A4 HUMAN

SC61B HUMAN

TGM3_HUMAN

PSA_HUMAN

RS10L HUMAN

RS26L HUMAN

R13P3_HUMAN

ODPB_HUMAN

KPYM_HUMAN

QOR_HUMAN

GDIA_HUMAN

IQGA1 HUMAN

RAC1 HUMAN

RAB10_HUMAN

RB11A HUMAN

RAB14 HUMAN

RAB1A_HUMAN

RAB1B_HUMAN

RAB25_HUMAN

RAB5C_HUMAN

RAB6A HUMAN

RAB7A_HUMAN

IASPP HUMAN 
FBRL_HUMAN

SCEL_HUMAN

SEPT2_HUMAN

SRSF1_HUMAN

TRFE HUMAN

SPB12_HUMAN

SPB5_HUMAN

ALBU_HUMAN

SAMP_HUMAN

STAT1_HUMAN SMD3_HUMAN SPTN1 HUMAN SBSN HUMAN VAT1_HUMAN TLN1_HUMAN TENA_HUMAN TENX_HUMAN TYPH_HUMAN

TALDO_HUMAN BGH3_HUMAN RHOA_HUMAN TAGL_HUMAN

TAGL2_HUMAN TERA_HUMAN TKT_HUMAN

TM109_HUMAN TMM43_HUMAN ECHA_HUMAN TPIS_HUMAN TRI29_HUMAN TPM1_HUMAN TPM3_HUMAN TPM4_HUMAN TPM2_HUMAN TRYB1_HUMAN TBA1A_HUMAN TBA4A_HUMAN TBB5 HUMAN

TBB2B_HUMAN TBB4A_HUMAN TBB4B HUMAN TPPP3_HUMAN RS27A_HUMAN UBE2N_HUMAN UBA1_HUMAN VIME_HUMAN VINC_HUMAN VDAC2_HUMAN VATA_HUMAN XRCC5_HUMAN XRCC6_HUMAN ZN185_HUMAN ZA2G_HUMAN

\begin{tabular}{|c|c|}
\hline 2 & 0.39 \\
\hline$<0.001$ & 0.29 \\
\hline$<0.001$ & 0.29 \\
\hline 1.5 & 0.79 \\
\hline 2.2 & 0.05 \\
\hline 0.5 & 0.52 \\
\hline 0.4 & 0.14 \\
\hline 1.4 & 0.0054 \\
\hline 2.4 & 0.27 \\
\hline 20 & 0.41 \\
\hline 0.7 & 0.23 \\
\hline 1.3 & 0.26 \\
\hline 0.8 & 0.61 \\
\hline$<0.001$ & 0.29 \\
\hline 16 & 0.11 \\
\hline 6.1 & 0.2 \\
\hline 1.4 & 0.44 \\
\hline 12 & 0.27 \\
\hline 1 & 0.9 \\
\hline 1.7 & 0.078 \\
\hline 1.2 & 0.64 \\
\hline 8 & 0.41 \\
\hline 0.6 & 0.2 \\
\hline 1.3 & 0.35 \\
\hline 0.9 & 0.81 \\
\hline 1 & 0.95 \\
\hline 0.8 & 0.86 \\
\hline 1.5 & 0.55 \\
\hline 0.5 & 0.23 \\
\hline 1.1 & 0.71 \\
\hline 32 & 0.21 \\
\hline$<0.001$ & 0.09 \\
\hline 1.1 & 0.86 \\
\hline 6.9 & 0.48 \\
\hline 2.8 & 0.14 \\
\hline 1.1 & 0.66 \\
\hline 0.8 & 0.68 \\
\hline 0.8 & 0.44 \\
\hline 0.9 & 0.88 \\
\hline 0.8 & 0.53 \\
\hline 1 & 0.83 \\
\hline 0.5 & 0.092 \\
\hline 0.4 & 0.18 \\
\hline 0.5 & 0.24 \\
\hline 1.4 & 0.37 \\
\hline 1.4 & 0.065 \\
\hline 0.9 & 0.88 \\
\hline 0.4 & 0.17 \\
\hline 0.9 & 0.89 \\
\hline 1.7 & 0.13 \\
\hline 2.3 & 0.17 \\
\hline 0.1 & 0.3 \\
\hline 0.7 & 0.53 \\
\hline
\end{tabular}


1433F_HUMAN

1433G_HUMAN

1433S_HUMAN

1433T_HUMAN

1433Z_HUMAN

DECR HUMAN

PRS6A HUMAN

PRS7_HUMAN

PRS8_HUMAN

PSMD2_HUMAN

SSMD3_HUMAN

HCD2_HUMAN

RS11 HUMAN

RS12 HUMAN

RS13_HUMAN

RS14_HUMAN

RS15A_HUMAN

RS16_HUMAN

RS17L_HUMAN

RS18_HUMAN

RS19_HUMAN

RS2_HUMAN

RS20_HUMAN

RS23_HUMAN

RS24_HUMAN

RS25_HUMAN

RS28_HUMAN

RS3_HUMAN

RS3A_HUMAN

RS4X_HUMAN

RS5_HUMAN

RS6_HUMAN

RS7_HUMAN

RS8 HUMAN

RS9_HUMAN

RSSA_HUMAN

AL9A1_HUMAN

CH60_HUMAN

RLAOL_HUMAN

RLA2_HUMAN

RL10_HUMAN

RL10A HUMAN

RL11_HUMAN

RL13_HUMAN

RL13A_HUMAN

RL14_HUMAN

RL17_HUMAN

RL18_HUMAN

RL18A_HUMAN

RL19_HUMAN

RL21_HUMAN

RL22_HUMAN

RL23_HUMAN

RL23A_HUMAN

RL24_HUMAN

RL26L_HUMAN

RL27_HUMAN

RL28_HUMAN

RL29_HUMAN

RL3_HUMAN

1.1

1.3

1.1

1.1 
ANXA2_HUMAN

ANXA4_HUMAN

ANXA5_HUMAN

ANXA6_HUMAN

ANXA8_HUMAN

AXA82_HUMAN

AP1S1_HUMAN

APOA1_HUMAN APOA2_HUMAN APOE HUMAN ASC_HUMAN ARGI1_HUMAN

ASSY_HUMAN

AATM_HUMAN

ATPA_HUMAN

AT5F1_HUMAN ATPB_HUMAN ATP5H_HUMAN ATP5I_HUMAN 
ATPG_HUMAN ATPO_HUMAN DHX9_HUMAN DDX3X_HUMAN

PGBM_HUMAN BAP31_HUMAN PGS1_HUMAN BLMH_HUMAN C1TC_HUMAN CALL3_HUMAN CALL5_HUMAN CALX_HUMAN CAN1_HUMAN ICAL_HUMAN CAH1_HUMAN CAH2 HUMAN CBR1_HUMAN CBPA4_HUMAN CASPE_HUMAN CATA_HUMAN CTNA1_HUMAN CTNB1_HUMAN CTND1_HUMAN CATD_HUMAN CATG_HUMAN CATL2_HUMAN CAV1_HUMAN CD44_HUMAN CDC42_HUMAN CERU_HUMAN CLIC1_HUMAN CMA1_HUMAN CLH1_HUMAN CLUS_HUMAN F13A_HUMAN COF1_HUMAN CO1A1_HUMAN CO2A1_HUMAN CO3A1_HUMAN CO6A1_HUMAN CO7A1_HUMAN COEA1_HUMAN COHA1_HUMAN CO1A2_HUMAN CO6A2_HUMAN CO6A3_HUMAN CO3_HUMAN CO9_HUMAN H2AY_HUMAN KCRB_HUMAN KCRU_HUMAN CAND1_HUMAN CYTM_HUMAN CRIP2_HUMAN CYC_HUMAN COX2_HUMAN ACOC_HUMAN DYHC1_HUMAN DC1/2_HUMAN CYFP1_HUMAN SERA_HUMAN DOPD_HUMAN PGS2_HUMAN HEM2_HUMAN DSC1_HUMAN

0.078 
Desmocollin-3 OS=Homo sapiens GN=DSC3 PE=1 SV=3 Desmoglein $-10 S=H o m o$ sapiens $G N=D S G 1 P E=1 S V=2$

DSC3_HUMAN

DSG1 HUMAN

DESP_HUMAN

DEST_HUMAN

Destrin OS=Homo sapiens GN=DSTN PE=1 SV=3

Dihydrolipoyllysine-residue succinyltransferase component of 2-oxoglutarate dehydrogenase complex

mitochondrial OS=Homo sapiens GN=DLST PE=1 SV=4

DNA damage-binding protein $1 \mathrm{OS}=$ Homo sapiens $\mathrm{GN}=\mathrm{DDB} 1 \mathrm{PE}=1 \mathrm{SV}=1$

DNA-(apurinic or apyrimidinic site) lyase OS=Homo sapiens GN=APEX1 PE=1 SV=2

Dolichyl-diphosphooligosaccharide--protein glycosyltransferase subunit DAD1 OS=Homo sapiens

GN=DAD1 PE=1 SV=3

EH domain-containing protein $2 \mathrm{OS}=$ Homo sapiens $\mathrm{GN}=\mathrm{EHD} 2 \mathrm{PE}=1 \mathrm{SV}=2$

Elastin OS=Homo sapiens $\mathrm{GN}=\mathrm{ELN} \mathrm{PE}=1 \mathrm{SV}=3$

ELAV-like protein $1 \mathrm{OS}=$ Homo sapiens $\mathrm{GN}=\mathrm{ELAVL1} \mathrm{PE}=1 \mathrm{SV}=2$

Elongation factor 1 -alpha $1 \mathrm{OS}=$ Homo sapiens $\mathrm{GN}=\mathrm{EEF} 1 \mathrm{~A} 1 \mathrm{PE}=1 \mathrm{SV}=1$

Elongation factor 1-beta OS=Homo sapiens $\mathrm{GN}=\mathrm{EEF} 1 \mathrm{~B} 2 \mathrm{PE}=1 \mathrm{SV}=3$

Elongation factor 1-delta OS=Homo sapiens $\mathrm{GN}=\mathrm{EEF} 1 \mathrm{D} P E=1 \mathrm{SV}=5$

Elongation factor 1-gamma OS=Homo sapiens $\mathrm{GN}=\mathrm{EEF} 1 \mathrm{G} P E=1 \mathrm{SV}=3$

Elongation factor $2 \mathrm{OS}=\mathrm{Homo}$ sapiens $\mathrm{GN}=\mathrm{EEF} 2 \mathrm{PE}=1 \mathrm{SV}=4$

Elongation factor $\mathrm{Tu}$, mitochondrial $\mathrm{OS}=$ Homo sapiens $\mathrm{GN}=\mathrm{TUFM} P E=1 \mathrm{SV}=2$

Emerin OS=Homo sapiens GN=EMD PE=1 SV=1

Endoplasmin OS=Homo sapiens GN=HSP90B1 PE=1 SV=1

Envoplakin OS=Homo sapiens GN=EVPL PE=1 SV=3

Epiplakin OS=Homo sapiens GN=EPPK1 PE=1SV=2

Eukaryotic initiation factor $4 A-I O S=H o m o$ sapiens $G N=E I F 4 A 1 P E=1 S V=1$

Eukaryotic translation initiation factor 2 subunit $1 \mathrm{OS}=$ Homo sapiens $\mathrm{GN}=\mathrm{EIF} 2 \mathrm{~S} 1 \mathrm{PE}=1 \mathrm{SV}=3$

Eukaryotic translation initiation factor 3 subunit $A$ OS $=$ Homo sapiens $G N=E I F 3 A P E=1 S V=1$

Eukaryotic translation initiation factor 3 subunit $B$ OS=Homo sapiens $G N=E I F 3 B \quad P E=1 S V=3$

Eukaryotic translation initiation factor 3 subunit $\mathrm{COS}=$ Homo sapiens $\mathrm{GN}=\mathrm{EIF} 3 \mathrm{C} P \mathrm{PE}=1 \mathrm{SV}=1$

Extracellular superoxide dismutase [Cu-Zn] OS=Homo sapiens GN=SOD3 PE=1 SV=2

Ezrin OS=Homo sapiens GN=EZR PE=1 SV=4

F-actin-capping protein subunit al pha- $1 \mathrm{OS}=$ Homo sapiens $\mathrm{GN}=\mathrm{CAPZA1} \mathrm{PE}=1 \mathrm{SV}=3$

F-actin-capping protein subunit al pha- $2 \mathrm{OS}=$ Homo sapiens $\mathrm{GN}=\mathrm{CAPZA} 2 \mathrm{PE}=1 \mathrm{SV}=3$

$F$-actin-capping protein subunit beta OS=Homo sapiens $G N=C A P Z B P E=1 S V=4$

Far upstream element-binding protein $2 \mathrm{OS}=$ Homo sapiens $\mathrm{GN}=\mathrm{KHSRP} P E=1 \mathrm{SV}=4$

Fatty acid synthase $O S=$ Homo sapiens $G N=F A S N ~ P E=1 S V=3$

Fatty acid-binding protein, brain OS=Homo sapiens $G N=F A B P 7 P E=1 S V=3$

Fatty acid-binding protein, epidermal OS=Homo sapiens $G N=F A B P 5 P E=1 \mathrm{SV}=3$

F-box only protein $50 \mathrm{OS}=$ Homo sapiens $\mathrm{GN}=\mathrm{NCCRP} 1 \mathrm{PE}=1 \mathrm{SV}=1$

Fibrinogen gamma chain $\mathrm{OS}=$ Homo sapiens $\mathrm{GN}=\mathrm{FGG} P E=1 \mathrm{SV}=3$

Fibronectin $\mathrm{OS}=$ Homo sapiens $\mathrm{GN}=\mathrm{FN} 1 \mathrm{PE}=1 \mathrm{SV}=4$

Fibulin-1 OS=Homo sapiens GN=FBLN1 PE=1 SV=4

Filaggrin $\mathrm{OS}=$ Homo sapiens $\mathrm{GN}=\mathrm{FLG} P E=1 \mathrm{SV}=3$

Filaggrin-2 OS=Homo sapiens $\mathrm{GN}=\mathrm{FLG} 2 \mathrm{PE}=1 \mathrm{SV}=1$

Filamin-A OS=Homo sapiens $G N=F L N A \quad P E=1 S V=4$

Filamin-B OS=Homo sapiens GN=FLNB PE $=1 \mathrm{SV}=2$

Flavin reductase $O S=$ Homo sapiens $G N=B L V R B P E=1 S V=3$

Fructose-bisphosphate aldolase $A$ OS=Homo sapiens $G N=A L D O A ~ P E=1 S V=2$

Fructose-bisphosphate aldolase $\mathrm{C}$ OS=Homo sapiens $\mathrm{GN}=\mathrm{ALDOC} \mathrm{PE}=1 \mathrm{SV}=2$

Galectin-1 OS=Homo sapiens GN=LGALS1 PE $=1 \mathrm{SV}=2$

Galectin-3 OS=Homo sapiens GN=LGALS3 PE $=1 \mathrm{SV}=5$

Galectin-7 OS=Homo sapiens GN=LGALS7 PE=1 SV=2

Galectin-related protein $\mathrm{OS}=$ Homo sapiens $\mathrm{GN}=\mathrm{GRP} P E=1 \mathrm{SV}=2$

Gamma-glutamylcyclotransferase OS=Homo sapiens $\mathrm{GN}=\mathrm{GGCT} P E=1 \mathrm{SV}=1$

Ganglioside $G M 2$ activator $O S=$ Homo sapiens $G N=G M 2 A \quad P E=1 S V=4$

Gasdermin- $A$ OS=Homo sapiens $G N=G S D M A ~ P E=2 S V=4$

Gelsolin OS=Homo sapiens $G N=G S N P E=1 S V=1$

Glucose-6-phosphate isomerase OS=Homo sapiens GN=GPI PE=1 SV=4

Glutamate dehydrogenase 1 , mitochondrial OS=Homo sapiens $G N=G L U D 1 P E=1 \mathrm{SV}=2$

Glutaredoxin-1 OS=Homo sapiens $\mathrm{GN}=\mathrm{GLRX} P E=1 \mathrm{SV}=2$

Glutathione peroxidase $3 \mathrm{OS}=$ Homo sapiens $\mathrm{GN}=\mathrm{GPX} 3 \mathrm{PE}=1 \mathrm{SV}=2$

Glutathione S-transferase kappa $1 \mathrm{OS}=$ Homo sapiens $\mathrm{GN}=\mathrm{GSTK} 1 \mathrm{PE}=1 \mathrm{SV}=3$

Glutathione S-transferase Mu 2 OS=Homo sapiens GN=GSTM2 PE=1 SV=2

Glutathione S-transferase Mu 5 OS=Homo sapiens GN=GSTM5 PE=1 SV=3

Glutathione S-transferase P OS=Homo sapiens GN=GSTP1 PE=1 SV=2

Glyceraldehyde-3-phosphate dehydrogenase OS=Homo sapiens GN=GAPDH PE=1 SV=3

Glycogen phosphorylase, brain form OS=Homo sapiens GN=PYGB PE=1 SV=5

Glycolipid transfer protein OS=Homo sapiens $\mathrm{GN}=\mathrm{GLTP} P E=1 \mathrm{SV}=3$
ODO2_HUMAN

DDB1 HUMAN

APEX1_HUMAN

DAD1_HUMAN

EHD2 HUMAN

ELN_HUMAN

ELAV1_HUMAN

EF1A1_HUMAN

EF1B_HUMAN

EF1D_HUMAN

EF1G_HUMAN

EF2_HUMAN

EFTU_HUMAN

EMD_HUMAN

ENPL_HUMAN

EVPL_HUMAN

EPIPL_HUMAN

IF4A1_HUMAN

IF2A_HUMAN

EIF3A_HUMAN

EIF3B_HUMAN

EIF3C HUMAN

SODE_HUMAN

CAZA1_HUMAN

CAZA2_HUMAN

CAPZB_HUMAN

FUBP2_HUMAN

FAS_HUMAN

FABP7_HUMAN

FABP5_HUMAN

FBX50 HUMAN

FIBG_HUMAN

FINC_HUMAN

FBLN1_HUMAN

FILA_HUMAN

FILA2 HUMAN

FLNA_HUMAN

FLNB_HUMAN

BLVRB_HUMAN

ALDOA_HUMAN

ALDOC_HUMAN

LEG1_HUMAN

LEG3_HUMAN

LEG7_HUMAN

LEGL HUMAN

SAP3 HUMAN

GSDMA_HUMAN

GELS_HUMAN

G6PI_HUMAN

DHE3 HUMAN

GLRX1_HUMAN

GPX3 HUMAN

GSTK1_HUMAN

GSTM2_HUMAN

GSTM5_HUMAN

GSTP1_HUMAN

G3P_HUMAN

PYGB_HUMAN

GLTP_HUMAN
EZRI_HUMAN

GGCT_HUMAN

\begin{tabular}{l|l}
0.8 & 0.54 \\
0.9 & 0.78 \\
1.1 & 0.62 \\
\hline 3.9 & 0.076 \\
&
\end{tabular}

0.06

0.2

$<0.001$

1.5

0.15

0.38

2.3

110

49

0.7

0.9

1

1.8

1.1

1.1

1

3.5

2.3

0.9

1.4

0.8

1.5

4.3

$<0.001$

$<0.001$

1.2

0.9

1

2.3

1.2

1.2

6

5.8

0.6

0.7

24

2.3

100

0.8

1.2

1.9

0.8

0.2

1.1

1.4

2.7

1.1

2.7

1.6

1.2

3.3

1.3

1.4

0.7

1.2

1.7

3.7

0.9

0.6

6

1.1

0.9

4.6

0.58

0.036

0.012

0.55

0.27

1

0.073

0.76

0.72

0.92

0.29

0.11

0.87

0.41

0.76

0.21

0.043

0.037

0.28

0.86

0.84

0.92

0.072

0.7

0.81

0.3

0.17

0.63

0.68

0.033

0.4

0.28

0.2

0.64

0.2

0.71

0.075

0.66

0.24

0.082

0.85

0.14

0.46

0.63

0.083

0.45

0.11

0.42

0.87

0.63

0.11

0.94

0.67

0.3

0.79

0.56

0.026 

HLA class I histocompatibility antigen, B-7 alpha chain OS=Homo sapiens $G N=H L A-B \quad P E=1 S V=3$ Hornerin OS=Homo sapiens GN=HRNR PE=1 SV=2

HNRPQ_HUMAN

HNRPU_HUMAN

ROA2_HUMAN

HNRPC_HUMAN

HXK1_HUMAN

HUTH_HUMAN

HRG_HUMAN

H10_HUMAN

H12_HUMAN

H12_HUMAN

H14_HUMAN

H15_HUMAN

H2A1B_HUMAN

H2AV_HUMAN

H2B1B_HUMAN

H2B1B_HUMAN

H2B1C_HUMAN

H31T_HUMAN

H4_HUMAN

1B13 HUMAN

1B15_HUMAN

1B51_HUMAN

1B07_HUMAN

HORN_HUMAN

HCDH_HUMAN

HPRT_HUMAN

IGHA1_HUMAN

IGHG1_HUMAN

IGHG2_HUMAN

IGKC_HUMAN

KV302_HUMAN

LAC2_HUMAN 
ITA6 HUMAN

ITB4 HUMAN

ILF2_HUMAN

INVO_HUMAN

IDHC_HUMAN

Isocitrate dehydrogenase [NADP] cytoplasmic OS=Homo sapiens GN=IDH1 PE=1 SV=2

Isocitrate dehydrogenase [NADP], mitochondrial OS=Homo sapiens $\mathrm{GN}=I D H 2 \mathrm{PE}=1 \mathrm{SV}=2$

Junction plakoglobin OS=Homo sapiens GN=JUP PE=1 SV=3

Keratin, type I cuticular Ha1 OS=Homo sapiens $G N=K R T 31$ PE=1 SV=3

Keratin, type I cuticular Ha1 OS=Homo sapiens $G N=K R T 31 P E=1 \mathrm{SV}=3$

Keratin, type I cuticular Ha3-I OS=Homo sapiens GN=KRT33A PE=1 SV=2

Keratin, type I cytoskeletal $10 \mathrm{OS}=$ Homo sapiens $\mathrm{GN}=\mathrm{KRT} 10 \mathrm{PE}=1 \mathrm{SV}=6$

Keratin, type I cytoskeletal $14 \mathrm{OS}=$ Homo sapiens $\mathrm{GN}=\mathrm{KRT} 14 \mathrm{PE}=1 \mathrm{SV}=4$ Keratin, type I cytoskeletal $15 \mathrm{OS}=$ Homo sapiens $\mathrm{GN}=\mathrm{KRT} 15 \mathrm{PE}=1 \mathrm{SV}=3$ Keratin, type I cytoskeletal $16 \mathrm{OS}=$ Homo sapiens $\mathrm{GN}=\mathrm{KRT} 16 \mathrm{PE}=1 \mathrm{SV}=4$ Keratin, type I cytoskeletal $17 \mathrm{OS}=$ Homo sapiens $\mathrm{GN}=\mathrm{KRT} 17 \mathrm{PE}=1 \mathrm{SV}=2$ Keratin, type I cytoskeletal $9 \mathrm{OS}=$ Homo sapiens $\mathrm{GN}=\mathrm{KRT} 9 \mathrm{PE}=1 \mathrm{SV}=3$ Keratin, type II cuticular Hb1 OS=Homo sapiens $\mathrm{GN}=\mathrm{KRT} 81 \mathrm{PE}=1 \mathrm{SV}=3$ Keratin, type II cytoskeletal 1 OS=Homo sapiens GN=KRT1 PE=1SV=6 Keratin, type II cytoskeletal $1 \mathrm{~b}$ OS=Homo sapiens $\mathrm{GN}=\mathrm{KRT77} \mathrm{PE}=1 \mathrm{SV}=3$ Keratin, type II cytoskeletal 2 epidermal OS=Homo sapiens $G N=K R T 2 P E=1 S V=2$ Keratin, type II cytoskeletal $5 \mathrm{OS}=$ Homo sapiens $\mathrm{GN}=\mathrm{KRT5} \mathrm{PE}=1 \mathrm{SV}=3$ Keratin, type II cytoskeletal $6 \mathrm{~A}$ OS=Homo sapiens $G N=K R T 6 A \quad P E=1 S V=3$ Keratin, type II cytoskeletal $6 C$ OS=Homo sapiens $G N=K R T 6 C P E=1 S V=3$ Keratin, type II cytoskeletal $78 \mathrm{OS}=$ Homo sapiens $\mathrm{GN}=\mathrm{KRT78} P \mathrm{PE}=1 \mathrm{SV}=2$ Keratin, type II cytoskeletal $80 \mathrm{OS}=$ Homo sapiens $\mathrm{GN}=\mathrm{KRT} 80 \mathrm{PE}=1 \mathrm{SV}=2$ Lactoylglutathione lyase OS=Homo sapiens $\mathrm{GN}=\mathrm{GLO} 1 \mathrm{PE}=1 \mathrm{SV}=4$ LanC-like protein $1 \mathrm{OS}=$ Homo sapiens $\mathrm{GN}=\mathrm{LANCL1} \mathrm{PE}=1 \mathrm{SV}=1$ Leucyl-tRNA synthetase, cytoplasmic OS=Homo sapiens GN=LARS PE=1 SV=2 Leukocyte elastase inhibitor OS=Homo sapiens $\mathrm{GN}=\mathrm{SERPINB1} P E=1 \mathrm{SV}=1$ L-lactate dehydrogenase $A$ chain OS=Homo sapiens $G N=L D H A P E=1 S V=2$ L-lactate dehydrogenase $B$ chain OS=Homo sapiens $G N=L D H B P E=1 S V=2$ Lumican OS=Homo sapiens GN=LUM PE=1 SV=2

Lysozyme C OS=Homo sapiens GN=LYZ PE=1 SV=1

Macrophage migration inhibitory factor OS=Homo sapiens GN=MIF PE=1 SV=4 Macrophage-capping protein OS=Homo sapiens GN=CAPG PE=1 SV=2

Malate dehydrogenase, cytoplasmic OS=Homo sapiens $\mathrm{GN}=\mathrm{MDH} 1 \mathrm{PE}=1 \mathrm{SV}=4$

Malate dehydrogenase, mitochondrial $O S=$ Homo sapiens $G N=M D H 2 P E=1 S V=3$

Mast cell carboxypeptidase $\mathrm{A}$ OS=Homo sapiens $\mathrm{GN}=\mathrm{CPA} 3 \mathrm{PE}=1 \mathrm{SV}=2$

Membrane-associated progesterone receptor component $2 \mathrm{OS}=$ Homo sapiens $G N=P G R M C 2 P E=1 S V=1$

Microtubule-associated protein $4 \mathrm{OS}=$ Homo sapiens $\mathrm{GN}=\mathrm{MAP} 4 \mathrm{PE}=1 \mathrm{SV}=3$

Mimecan OS=Homo sapiens GN=OGN PE=1 SV=1

Moesin OS=Homo sapiens $\mathrm{GN}=\mathrm{MSN} P E=1 \mathrm{SV}=3$

Myosin light polypeptide $6 \mathrm{OS}=$ Homo sapiens $\mathrm{GN}=\mathrm{MYL6} \mathrm{PE}=1 \mathrm{SV}=2$

Myosin regulatory light chain 12A OS=Homo sapiens $G N=M Y L 12 A \quad P E=1 S V=2$

Myosin-14 OS=Homo sapiens GN=MYH14 PE=1 SV=1

Myosin-9 OS=Homo sapiens GN=MYH9 PE=1 SV=4

Myosin-Ic OS=Homo sapiens GN=MYO1C PE=1 SV=4

NADH dehydrogenase [ubiquinone] iron-sulfur protein 3, mitochondrial OS=Homo sapiens GN=NDUFS3 $P E=1 S V=1$

NADH-cytochrome b5 reductase $1 \mathrm{OS}=$ Homo sapiens $\mathrm{GN}=\mathrm{CYB} 5 \mathrm{R} 1 \mathrm{PE}=1 \mathrm{SV}=1$

NADH-cytochrome b5 reductase $3 \mathrm{OS}=$ Homo sapiens $\mathrm{GN}=\mathrm{CYB5R} 3 \mathrm{PE}=1 \mathrm{SV}=3$

Nascent polypeptide-associated complex subunit alpha, muscle-specific form OS=Homo sapiens

GN=NACA PE=1 SV=1

Neuroblast differentiation-associated protein $A H N A K$ OS=Homo sapiens $G N=A H N A K ~ P E=1 S V=2$

Neutral alpha-glucosidase $A B$ OS=Homo sapiens GN=GANAB PE=1 SV=3

Niban-like protein $10 \mathrm{O}=$ Homo sapiens $\mathrm{GN}=\mathrm{FAM} 129 \mathrm{~B} P \mathrm{PE}=1 \mathrm{SV}=2$

Non-histone chromosomal protein HMG-14 OS=Homo sapiens GN=HMGN1 PE=1 SV=3

Nucl eolin OS=Homo sapiens GN=NCLPE=1SV=3

Nucleophosmin OS=Homo sapiens GN=NPM1 PE=1 SV=2

Nucleoside diphosphate kinase $A$ OS=Homo sapiens $G N=N M E 1 P E=1 S V=1$

Nucl eoside diphosphate kinase $A$ OS=Homo sapiens $G N=N M E 1 P E=1 S V=1$

Obg-like ATPase $1 \mathrm{OS}=$ Homo sapiens $\mathrm{GN}=\mathrm{OLA} 1 \mathrm{PE}=1 \mathrm{SV}=2$

IDHP_HUMAN

PLAK_HUMAN

K1H1_HUMAN

K1H1_HUMAN

KT33A_HUMAN

K1C10_HUMAN

K1C14_HUMAN

K1C15_HUMAN

K1C16_HUMAN

K1C17_HUMAN

K1C9_HUMAN

KRT81 HUMAN

K2C1_HUMAN

K2C1B_HUMAN

K22E_HUMAN

K2C5_HUMAN

K2C6A_HUMAN

K2C6C_HUMAN

K2C78_HUMAN

K2C80_HUMAN

LGUL_HUMAN

LANC1_HUMAN

SYLC_HUMAN

ILEU_HUMAN

LDHA_HUMAN

LDHB HUMAN

LUM_HUMAN

LYSC_HUMAN

MIF_HUMAN

CAPG_HUMAN

MDHC_HUMAN

MDHM_HUMAN

CBPA3_HUMAN

PGRC2_HUMAN

MAP4_HUMAN

MIME HUMAN

MOES HUMAN

MYL6_HUMAN

ML12A_HUMAN

MYH14_HUMAN

MYH9 HUMAN

MYO1C HUMAN

NDUS3_HUMAN

NB5R1_HUMAN

NB5R3_HUMAN

0.35

0.92

0.97

0.74

0.91

0.26

0.29

1

0.95

0.3

0.34

0.58

0.2

0.028

0.032

0.7

0.57

NACAM_HUMAN 
PRDX1_HUMAN

PRDX2 HUMAN

PRDX5 HUMAN

PRDX6_HUMAN

MPCP_HUMAN

PEBP1_HUMAN

PGK1_HUMAN

PGAM1_HUMAN

PMVK_HUMAN

PKP1_HUMAN

PKP3_HUMAN

PAIRB_HUMAN

PLSL_HUMAN

PLST_HUMAN

PLEC_HUMAN

PCBP1_HUMAN

PTBP1_HUMAN

LMNA_HUMAN

PROF1_HUMAN

PDC6I_HUMAN

PDCD6_HUMAN

PHB_HUMAN

PHB2 HUMAN

PRELP_HUMAN

PSME2_HUMAN

PSA1 HUMAN

PSA2_HUMAN

PSA3_HUMAN

PSA4_HUMAN

PSA6_HUMAN

PSA7L_HUMAN

PSB4_HUMAN

PSB5_HUMAN

PSB6 HUMAN

AHNK2_HUMAN

PDIA3_HUMAN

PARK7_HUMAN

POF1B_HUMAN

S10AA_HUMAN

S1OAB HUMAN

S1OAE_HUMAN

S10AG_HUMAN

S10A2 HUMAN

S10A4_HUMAN

SC61B_HUMAN

PSA_HUMAN

UCRIL_HUMAN

HGB1A HUMAN

ST134_HUMAN

KPYM_HUMAN

QOR_HUMAN

GDIB HUMAN

IQGA1 HUMAN

RAC1_HUMAN

RAB10_HUMAN

RB11A_HUMAN

RAB14_HUMAN

RAB18_HUMAN

RAB1A_HUMAN

RAB1A_HUMAN
2.1

1.6

3.1

1.4

0.8 
RAB25 HUMAN

RAB2A_HUMAN

RAB5B_HUMAN

RAB5C_HUMAN

RAB6A HUMAN

RAB7A HUMAN

RAB8A_HUMAN

RALA_HUMAN

RAP1A HUMAN

RAP2B_HUMAN

REEP5_HUMAN

F213A HUMAN

APRV1_HUMAN

GDIR1_HUMAN

GDIR2 HUMAN

RINI_HUMAN

SCEL_HUMAN

SEPT2_HUMAN

SEPT7_HUMAN

HTRA1_HUMAN

SRSF2_HUMAN

SRSF3_HUMAN

TRFE_HUMAN

SPA12_HUMAN

SPB12_HUMAN

SPB5_HUMAN

ALBU_HUMAN

SAMP_HUMAN

ESTD_HUMAN

SH3L3_HUMAN

SFXN3_HUMAN

SRP14_HUMAN

SMD2_HUMAN

SMD3_HUMAN

SORCN_HUMAN

SPTN1_HUMAN

SPTB2_HUMAN

SFPQ_HUMAN

SND1_HUMAN

GRP75 HUMAN

SODC_HUMAN

SODM HUMAN

SBSN_HUMAN

SURF4_HUMAN

VAT1_HUMAN

TLN1_HUMAN

TCPD_HUMAN

TENX_HUMAN

TXD17_HUMAN

PRDX3_HUMAN

TALDO_HUMAN

BGH3_HUMAN

RHOA HUMAN

TAGL2 HUMAN

TERA_HUMAN

TKT_HUMAN

SSRD_HUMAN

TMEDA_HUMAN

GPNMB_HUMAN

TMM33_HUMAN

TMM43_HUMAN

TTHY_HUMAN

ECHA_HUMAN

ECHB_HUMAN

TPIS_HUMAN

\section{4}

0.07

0.7

1.3

1.9

0.9

3.9

1.8

2

3.6

1.4

1.7

1.4

1.5

0.9

0.2

1.1

1.1

19

0.9

1.7

1

7.2

0.8

1.2

1.4

17

0.1

1.9

4.1

1.4

12

4.1

1.5

2.8

3.8

0.2

0.07

0.3

2.2

5.6

2.1

0.1

9.7

0.7

0.8

0.7

0.8

2.7

1

0.7

1.4

1.2

2.1

1.4

1.1

3.8

1.6

0.3

13

0.6

0.06 
Tripartite motif-containing protein $290 \mathrm{OS}=$ Homo sapiens $\mathrm{GN}=\mathrm{TRIM} 29 \mathrm{PE}=1 \mathrm{SV}=2$

Tropomyosin alpha- 3 chain OS=Homo sapiens GN=TPM3 PE=1 SV=1

Tropomyosin alpha- 3 chain OS=Homo sapiens GN=TPM3 PE=1 SV=1

Tryptase al pha/beta- 1 OS=Homo sapiens $\mathrm{GN}=\mathrm{TPSAB} 1 \mathrm{PE}=1 \mathrm{SV}=1$

Tubulin alpha-1B chain OS=Homo sapiens $G N=T U B A 1 B P E=1 S V=1$

Tubulin alpha-4A chain OS=Homo sapiens $G N=T U B A 4 A P E=1 S V=1$

Tubulin beta chain OS=Homo sapiens $G N=T U B B P E=1 S V=2$

Tubulin beta- $4 A$ chain $O S=$ Homo sapiens $G N=T U B B 4 A P E=1 S V=2$

Tubulin beta-4B chain OS=Homo sapiens $G N=T U B B 4 B$ PE $=1 \mathrm{SV}=1$

Tubulin polymerization-promoting protein family member $3 \mathrm{OS}=$ Homo sapiens $\mathrm{GN}=\mathrm{TPPP} 3 \mathrm{PE}=1 \mathrm{SV}=1$

Ubiquitin carboxyl-terminal hydrolase $5 \mathrm{OS}=$ Homo sapiens $\mathrm{GN}=\mathrm{USP} 5 \mathrm{PE}=1 \mathrm{SV}=2$

Ubiquitin-60S ribosomal protein $L 40$ OS=Homo sapiens $G N=U B A 52 P E=1 S V=2$

Ubiquitin-60S ribosomal protein $L 40$ OS=Homo sapiens $G N=U B A 52 P E=1 S V=2$

Ubiquitin-conjugating enzyme E2 N OS=Homo sapiens $\mathrm{GN}=\mathrm{UBE} 2 \mathrm{~N} P E=1 \mathrm{SV}=1$

Ubiquitin-like modifier-activating enzyme $10 S=$ Homo sapiens $G N=U B A 1 P E=1 S V=3$

Vacuolar protein sorting-associated protein $35 \mathrm{OS}=$ Homo sapiens $\mathrm{GN}=\mathrm{VPS} 35 \mathrm{PE}=1 \mathrm{SV}=2$

Vesicle-trafficking protein $S E C 22 b$ OS=Homo sapiens $G N=S E C 22 B \quad P E=1 S V=4$

Vimentin OS=Homo sapiens GN=VIM PE=1 SV=4

Vinculin OS=Homo sapiens $\mathrm{GN}=\mathrm{VCLPE}=1 \mathrm{SV}=4$

Vitronectin OS=Homo sapiens GN=VTN PE=1 SV=1

Voltage-dependent anion-selective channel protein $10 \mathrm{OS}=$ Homo sapiens $\mathrm{GN}=\mathrm{VDAC} 1 \mathrm{PE}=1 \mathrm{SV}=2$

Voltage-dependent anion-selective channel protein $2 \mathrm{OS}=$ Homo sapiens $\mathrm{GN}=\mathrm{VDAC} 2 \mathrm{PE}=1 \mathrm{SV}=2$

Voltage-dependent anion-selective channel protein $3 \mathrm{OS}=$ Homo sapiens $\mathrm{GN}=\mathrm{VDAC} 3 \mathrm{PE}=1 \mathrm{SV}=1$

$V$-type proton ATPase catalytic subunit A OS=Homo sapiens $G N=A T P 6 V 1 A$ PE $=1 \mathrm{SV}=2$

$X$-ray repair cross-complementing protein 5 OS=Homo sapiens $G N=X R C C 5 P E=1 \mathrm{SV}=3$

$X$-ray repair cross-complementing protein $6 \mathrm{OS}=$ Homo sapiens $\mathrm{GN}=\mathrm{XRCC} 6 \mathrm{PE}=1 \mathrm{SV}=2$

Zinc finger protein $185 \mathrm{OS}=$ Homo sapiens $\mathrm{GN}=\mathrm{ZNF} 185 \mathrm{PE}=1 \mathrm{SV}=3$

Zinc-alpha-2-glycoprotein OS=Homo sapiens GN=AZGP1 PE=1 SV=2

\begin{tabular}{|c|c|c|}
\hline TRI29_HUMAN & 0.6 & 0.12 \\
\hline TPM3_HUMAN & 1.8 & 0.4 \\
\hline TPM3_HUMAN & 1.4 & 0.66 \\
\hline TRYB1_HUMAN & 1.1 & 0.91 \\
\hline TBA1B_HUMAN & 0.9 & 0.42 \\
\hline TBA4A_HUMAN & 1.4 & 0.41 \\
\hline TBB5_HUMAN & 0.7 & 0.019 \\
\hline TBB4A_HUMAN & 0.7 & 0.032 \\
\hline TBB4B_HUMAN & 0.7 & 0.029 \\
\hline TPPP3_HUMAN & 0.8 & 0.77 \\
\hline UBP5_HUMAN & 0.7 & 0.8 \\
\hline RL40_HUMAN & 1.6 & 0.52 \\
\hline RL40_HUMAN & 0.3 & 0.42 \\
\hline UBE2N_HUMAN & 2 & 0.32 \\
\hline UBA1_HUMAN & 0.5 & 0.39 \\
\hline VPS35_HUMAN & 3.3 & 0.27 \\
\hline SC22B_HUMAN & 2.8 & 0.36 \\
\hline VIME_HUMAN & 1.2 & 0.23 \\
\hline VINC_HUMAN & 0.1 & 0.37 \\
\hline VTNC_HUMAN & 1000 & 0.00043 \\
\hline VDAC1_HUMAN & 1.3 & 0.66 \\
\hline VDAC2_HUMAN & 0.7 & 0.56 \\
\hline VDAC3_HUMAN & $<0.001$ & 0.39 \\
\hline VATA_HUMAN & 1.1 & 0.92 \\
\hline XRCC5_HUMAN & 2.3 & 0.12 \\
\hline XRCC6_HUMAN & 0.5 & 0.3 \\
\hline ZN185_HUMAN & 0.1 & 0.44 \\
\hline ZA2G_HUMAN & 1.6 & 0.43 \\
\hline
\end{tabular}

